\title{
Academica Turistica
}

Tourism \& Innovation Journal Revija za turizem in inovativnost

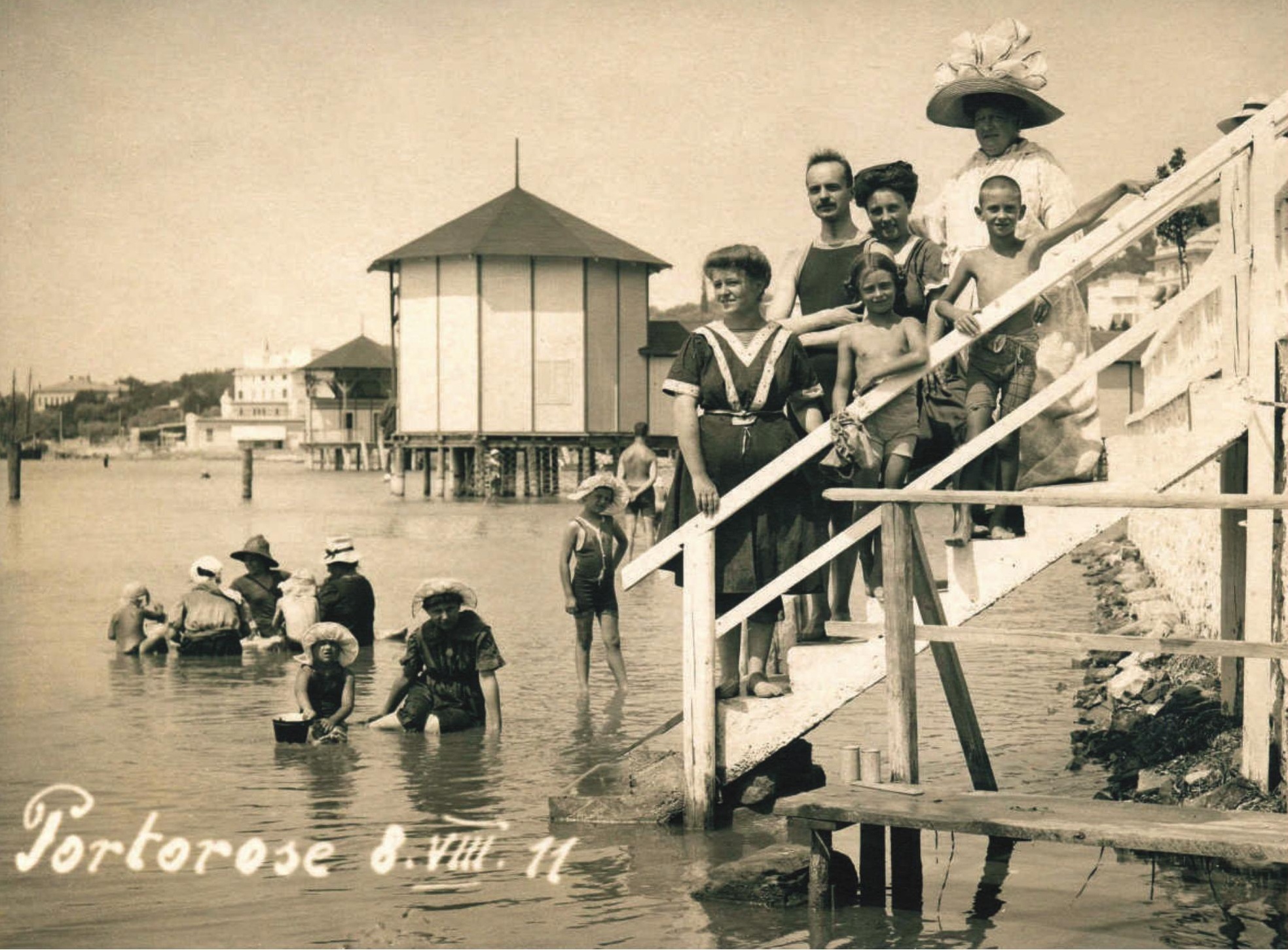





\title{
Academica Turistica
}

Tourism \& Innovation Journal - Revija za turizem in inovativnost

YEAR 12, No. 1, JUNE 2019, ISSN 2335-4194

https://doi.org/10.26493/2335-4194.12(1)

\author{
3 Editorial \\ Tomi Brezovec
}

5 Visitors to Greek Thermal and Seaside Spas (Mid-19th Century-Early 2oth Century) Melina Kostidi

13 Leisure and Commerce: Seafront Rivals in England's First Seaside Resorts Allan Brodie

23 The City and the Sea: Evolution and Transformation of a Controversial Relationship Annarita Teodosio

31 Inventing Tourism in the Naval Port: The Case of the Brijuni Islands

during the Habsburg Empire

Nataša Urošević

41 Tourism on the Croatian Adriatic Coast and World War I

Jasenka Kranjčević

55 Examining the Seasonality of Travel-Related Expenditure by Travel Purpose:

The Case of Japan

Kenichi Shimamoto

73 The Differences in Perceptions of Organisational Values in the Hospitality Sector:

What Do They Tell Us?

Mitja Gorenak

83 The Branded Hotel as an Element of Destination Branding

Elizabeth Abiola-Oke

97 Abstracts in Slovene - Povzetki v slovenščini

101 Instructions for Authors

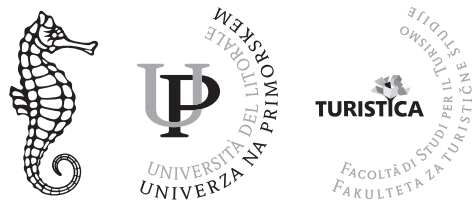

UNIVERSITY OF PRIMORSKA PRESS 
Executive Editor Janez Mekinc

Editor-in-Chief Gorazd Sedmak

Associate Editors Aleksandra Brezovec, Mitja Gorenak, and Dejan Križaj

Technical Editors Maja Trošt and Peter Kopić

Production Editor Alen Ježovnik

\section{Editorial Board}

Tanja Armenski, University of Novi Sad, Serbia

Rodolfo Baggio, University di Bocconi, Italy

Štefan Bojnec, University of Primorska, Slovenia

Dimitrios Buhalis, Bournemouth University, UK

Alan Clarke, Pannonian University, Hungary

Frederic Dimanche, Ryerson University, Canada

Jesse Dixon, San Diego State University, USA

Johan Edelheim, Hokkaido University, Japan

Felicite Fairer-Wessels, University of Pretoria,

South Africa

Doris Gomezelj Omerzel, University of Primorska, Slovenia

Sotiris Hji-Avgoustis, Ball State University, USA

Jafar Jafari, University of Wisconsin-Stout, USA,

University of Algarve, Portugal

Sandra Jankovič, University of Rijeka, Croatia

Anna Karlsdóttir, University of Iceland, Iceland

Maja Konečnik Ruzzier, University of Ljubljana, Slovenia

Sonja Sibila Lebe, University of Maribor, Slovenia

Mara Manente, Cà Foscari University of Venice, Italy

Yoel Mansfeld, University of Haifa, Israel

Tanja Mihalič, University of Ljubljana, Slovenia

Matjaž Mulej, University of Maribor, Slovenia

Milena Peršič, University of Rijeka, Croatia

Jasna Potočnik Topler, University of Maribor, Slovenia

Caroline Ritchie, University of Welsh Institute, UK

Vinod Sasidharan, San Diego State University, USA

Regina Schlüter, National University of Quilmes, Argentina

Marianna Sigala, University of the Aegean, Greece

Cristina Roxana Tănăsescu, Lucian Blaga University,

Romania

Andreja Trdina, University of Maribor, Slovenia

John K. Walton, Ikerbasque, Instituto Valentín de

Foronda, University of the Basque Country, Spain
Suosheng Wang, Indiana University-Purdue

University Indianapolis, USA

Indexed in Scopus, Erih Plus, С А В Abstracts, CIRET, EBSCO, and EconPapers.

Published by University of Primorska Press

University of Primorska

Titov trg 4, SI-60oo Koper

E-mail: zalozba@upr.si

Web: http://www.hippocampus.si

Editorial Office Academica Turistica

Faculty of Tourism Studies - Turistica

Obala 11a, SI-6320 Portorož, Slovenia

Telephone: +386 5 617-70-00

Fax: $+3865617-70-20$

E-mail: academica@turistica.si

Web: http://academica.turistica.si

Subscriptions The journal is distributed free of charge. For information about postage and packaging prices, please contact us at academica@turistica.si.

Copy Editor Terry Troy Jackson

Cover Design Mateja Oblak

Cover Photo Portorose, postcard from the collection of Tomi Brezovec

Printed in Slovenia by Birografika Bori, Ljubljana

Print Run 100 copies

Errata The author of the cover photo in Vol. 11, No. 2 is Šarolta Godnič Vičič.

Academica Turistica - Revija za turizem in inovativnost je znanstvena revija, namenjena mednarodni znanstveni in strokovni javnosti; izhaja $v$ angleščini s povzetki v slovenščini. Izid publikacije je finančno podprla Agencija za raziskovalno dejavnost Republike Slovenije iz sredstev državnega proračuna iz naslova razpisa za sofinanciranje domačih znanstvenih periodičnih publikacij.

ISSN 1855-3303 (printed)

ISSN 2335-4194 (online)

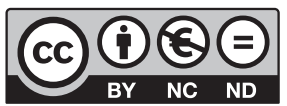




\title{
Editorial
}

\author{
Tomi Brezovec \\ Guest Editor \\ University of Primorska, Faculty of Tourism Studies - Turistica, Slovenia \\ tomi.brezovec@fts.upr.si \\ https://doi.org/10.26493/2335-4194.12.3-4
}

Today, bathing in the sea, sunbathing and enjoying various activities at the coast attract millions of people of all classes and ages and represent the most frequent form of spending summer holidays. Seaside promenades, hotels with sea views, restaurants and bars offering local or international food, amusement parks, entertainment centres, casinos and shops can be found at every seaside town that has recognised tourism as an opportunity for its growth and development.

The collection of articles on historic perspective on seaside tourism focuses on specific problems encountered during its development. Papers tackle issues such as the rivalry between tourism and traditional industries, impact of social and/or political factors on its development and the impact of its development on the transformation of the waterfront areas.

Compared to traditional seaside activities such as fishing, shipping or shipbuilding, seaside tourism has not a long tradition. Sea bathing was a new form of the use of the sea introduced about two centuries ago. First seaside resorts emerged in small English coastal towns in early 18th century. In his article on leisure and commerce in those first seaside resorts, Brodie discusses seaside tourism development in towns that were already established fishing or commercial ports. With increasing popularity of sea-bathing, it became necessary to build adequate infrastructure to satisfy the needs of growing number of visitors. This caused the rivalry between tourism and traditional trades for the use of the waterfront. The outcome of this dispute was not uniform; sometimes the development of commercial port pushed tourism to the outskirts of the town while in other instances tourism took over the abandoned infrastructure of cessed commercial activities.
By the 19th century, sea-bathing popularity expanded to the southern coasts of Europe. New resorts were emerging along the coasts of France, Spain, Italy and other countries. On the Adriatic, the first seabaths were built during the first half of the 19th century in Trieste and Venice, where they invented floating bathing establishments, anchored in the sea, close to the centre of the town. The two towns were in constant competition for the prestigious title of having the finest baths and were constantly enlarging existing and adding new baths. The competition ended by the end of the century with the development of numerous seaside resorts on both shores of the Adriatic. The paper from Uroševič discusses the development of tourism on Brijuni Islands in the proximity of Pula, the major naval port of the Austrian-Hungarian Empire. Brijuni have developed from malaria-infested islands into an elite resort in less than two decades. Further development was interrupted by the outbreak of the First World War has that has put to rest many other investments along the east coast of the Adriatic as reported in Kranjčevičss paper. During the last decades of the 19th and pre-WWI years of the 2oth century, tourism experienced fast development and many investors saw their opportunity in emerging seaside resorts. Investing on the waterfront was very profitable and every year new hotels, restaurants and entertainment establishments as well as private villas were available to visitors. To gain a better understanding of the scale of tourism investments during that period, projects that were halted and/or abandoned due to the outbreak of the war should also be taken into account. These projects also demonstrate how external political factors impact on tourism development. 
Tourism in Greece has followed a similar development path. After some initial developments during 19th century when visitors in Greece discovered seaside bathing, the pre-war period brought significant changes in terms of scale of investments, structure of visitors and volume of tourism business. In her paper, Kostidi presents insights into development of some early Greek spa and seaside resorts and their transformation from domestic into international destinations. The paper also focuses on changes of social structure of their visitors and discusses some governmental measures that were crucial for tourism development.

Teodosio's article discusses the process of regeneration of the waterfront within a wider geographical context and describes practices introduced in Spain and Italy. The development of urban areas around the commercial port has often set the limit to further expansion of commercial activities. Their development was thus possible only by moving commercial activity to a new location, abandoning the infrastructure close to or within the city centre. Reuse of abandoned and degraded industrial waterfront areas became a key area of urban planning. In many cities, these areas have been transformed into an attractive environment for locals and tourists alike.
Centuries ago, bringing tourism to the shores of the sea was a challenging venture. The sea was unattractive for visitors and uncompetitive to established inland thermal and spa centres. However, when seaside environment was recognised as being beneficial for health, the coast soon became a fashionable place. The aim of this set of articles is to contribute to better understanding of this early development phase of seaside tourism destinations. Learning from past experiences does provide useful knowledge needed for development of new destinations and for solving contemporary seaside tourism issues.

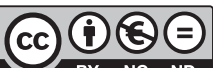

This paper is published under the terms of the Attribution- NonCommercial-NoDerivatives 4.0 International (CC B Y-NC-ND 4.O) License. 


\title{
Visitors to Greek Thermal and Seaside Spas (Mid-19th Century-Early 2oth Century)
}

\author{
Melina Kostidi \\ University of Thessaly, Greece \\ melinakostidi@hotmail.com
}

Thermal tourism is considered the first form of tourism in the 19th-century Greek state. At that time, patients decided to travel to Greek thermal baths to seek therapy and pain relief. The first thermal spas in Greece can be considered 'latecomers', because they began to develop after their counterparts in other areas of Europe, and they had few and limited facilities. However, in the mid-19th century, the urban space of Greek thermal spas and seaside resorts began to transform architecturally due to measures taken according to state policy and the increasing number of visitors. In this paper, I will attempt to study the architectural transformation of Greek spas and the profile of visitors and patients in the two phases of their development. My research is based on 19th-century primary sources (laws and doctrines, patient registries, medical reports, advertisements, postcards, novels and memoirs). I will assert that in the first stage of their development (1833-189o) Greek resorts had minimal accommodation and leisure facilities. Their clientele consisted of patients and travellers from nearby locations who encountered the lack of proper medical care and accommodation establishments. In their next phase (1890-1930), the urban space of Greek spas was transformed to cater to the needs of a different clientele. Visitors to Greek spas were patients and holidaymakers who usually travelled with other family members. The square and the promenade of thermal spas and seaside resorts became centres of urban sociability. They stayed at luxury hotels, and they enjoyed the sociability of modern facilities (restaurants, theatres, and casinos).

Keywords: spas, seaside resorts, leisure, tourism, Greece

https://doi.org/10.26493/2335-4194.12.5-12

\section{Introduction}

In the 21st century, travellers can plan a trip to any destination they wish easily and quickly thanks to technological and transport innovations. When they arrive at the tourism destination of their choice, several accommodation and leisure amenities can cater to all their needs. It could be claimed that modern travellers face few or no difficulties in comparison to the transport and accommodation problems that 19th-century travellers had to overcome. However, these problems did not seem to deter the first patients who travelled to Greek spas to seek thermal therapy. Although they were aware of the transport difficulties and the lack of proper amenities, these patients and visitors sought the 'world of Greek baths.'

This paper presents the profile of these patients and visitors in the two periods of development of Greek spas. In the first period (1833-1890), patients travelled mainly alone, while in the next period (18901930) they took their families with them for vacations and they seemed to show a higher preference for seaside resorts that had entertainment facilities. Primary sources (patient registries, medical treatises, advertisements, travel guides, literary and autobiographical 
texts were used to highlight the gender, interests, and diseases of patients and visitors (men and women of different classes) to Greek spas. The poor patients were also a particular but 'neglected' category of the public of Greek baths, as they also travelled to them and received proper care.

\section{The First Patients and Visitors to Greek Spas (1833-1890)}

The period $1833-1890$ is considered a crucial point in the development of Greek spas, as in this period, their urban space began to transform, and their first clientele was formed (Dritsas, 2002). The spas that welcomed the first patients were Kythnos, followed by Edipsos, Hypati, Loutraki, Methana, Kyllini, and Faliro (Varella, 2001a; 2001b). These first resorts had two main advantages that favoured their gradual development: they were conveniently located, and patients could travel to them quite easily from Athens and from the nearby cities and islands. All of them (Hypati excluded) were seaside towns, and thus, they were accessible by sea. Apart from the fact that the sea facilitated relatively easy transportation, the seafront gradually became an integral part of the urban space of Greek spas. Taking sea baths, which were initially recommended to patients by their doctors, quickly became a fashionable trend. In contrast, the various accommodation and leisure facilities (hotels, restaurants, coffee shops) that were constructed on their seafront in this period facilitated the sociability among patients and their escorts.

The first patients who visited the Greek baths for cure were those of the Cycladic island of Kythnos. They travelled to this spa town in the 1830 s seeking thermal therapy upon the recommendations of doctors and writers of medical treatises who praised the healing properties of the thermal waters (Landerer, 1850). Their number showed a remarkable increase, especially after the visits of the royal couple Otto and Amalia. Queen Amalia made use of the baths of Kythnos, because she was hoping to overcome her gynaecological problems and be able to conceive an heir. The first records of patients on Kythnos began immediately after the establishment of the bathing facilities (Kardamitsi-Adami, 2001). The caretakers and baths doctors recorded with great care the gender, occupations, and diseases of patients as well as the effects that the hot water had on their health. Thus, these patient registries are critical archival sources that provide information on the profile of the first Kythnos patients.

In 1844, during the bathing season (June to October), 50 patients received care in the bathhouse of Kythnos. The patient registry of the year 1847 is extremely meticulous, since the name, occupation, and diseases of the 58 patients and the effects of the hot baths were recorded. The patients of 1849 totalled 101. The patient registry 1851 , also written with great care and detail, shows 172 patients (men and women) who lived in various regions of Greece (Ministry of Interior $1845,1848,1851,1861$ ).

Eight years later Katakouzinos, the doctor of Kythnos baths wrote a medical report on the patients travelling to Kythnos. The 272 patients lived in Athens, or they were locals. Others came from the nearby $\mathrm{Cy}$ cladic islands or large Greek city centres. More specifically, 56 patients lived in Athens, 47 lived on Syros, 40 were locals from Kythnos, 17 lived in Nafplio, and 11 in Patras, while three patients came from Smyrna and one from Istanbul (Ministry of Interior Archive, 1861).

Another essential primary source for the number and the diseases of Kythnos patients is the 1835 treatise on the baths of Kythnos, written by a Bavarian chemist Xavier Landerer. His treatise was based on the fieldwork and scientific observations of bath doctors Konstantinos Drosinis and Gregorius Despotopoulos. According to the chemist, the Kythnos bathhouse had 200-250 patients annually. During the 14 months of its operation, 500 patients received treatment. Only 84 could afford to stay in the baths of Kythnos for an extended period and receive medical care. Most of them suffered from rheumatism, arthritis, or venereal diseases, and they noticed that the mineral waters of Kythnos offered them some relief. The 80 female patients suffered from gynaecological problems. In the next decades, the number of patients showed a gradual increase due to the expansion of the royal bathhouse and the appointment of a spa doctor. According to the medical observations of the spa doctor Gregorius Despotopoulos, in 1847-1849, the number of Kythnos patients stood around 300-400 per year, and those 
who had received hot water treatment for three consecutive years fully recovered (Kandylis, 1981).

For the patients, the trip to Kythnos was a real adventure, since in the first years no steamboat would facilitate the access to the island. Upon arrival, patients had to cope with inadequate accommodation facilities. It is worth noting that even in the first years of Kythnos, social segregation existed: The poor patients found accommodation in two other buildings and at a small church, and they were separated from those who stayed at the bathhouse. The price of a bath was half drachma and of a room was one and a half drachma. The Kythnos spa doctor, Gregorius Despotopoulos requested that there should be a room price adjustment according to the number of patients in each bathing season (Ministry of Interior, 1864). The bathing and accommodation facilities were improved when the doctor Aggelis Hantzaras rented the baths for twenty years in 1871 (Efimeris tis Kyverniseos, 23-24 March 1871).

The poorer patients of Kythnos baths are a 'neglected' and perhaps unknown category of their public. According to their request letters, these patients were eligible to free travel and free use of baths. They usually requested to be sent to the spa for therapy during the summer months, from April to July (when the thermal baths were open, and the number of patients was high). In their request letters, they stated that thermal therapy was a necessity to them, as they suffered from chronic pains, and they were unable to work and look after themselves. The surviving documents provide evidence about their gender, their residence, their health problem, and in some cases their occupation. According to their poverty certificates, they were mainly internal migrants: they lived in the Municipality of Athens (and one lived in the Municipality of Piraeus), but they were born in other different regions of Greece. The lack of reference to their occupation could imply that their disease prevented them from working. Their most common diseases were arthritis and rheumatism, and there was one case of a woman who suffered from a gynaecological problem (Ministry of Interior 1845, 1848, 1851, 1861, 1864).

The patients of Kythnos baths could be considered an interesting case study for a researcher of the his- tory of medicine because they were the first public who trusted and used the thermal baths for healing. In the following decades, the growing interest on behalf of the public resulted in a gradual development of other spa resorts. These Greek spas were: Hypati, Edipsos, Methana and Loutraki. Although in their beginnings they had minimal accommodation facilities, and their patients faced the similar problems as those in Kythnos, the number of their visitors continued to grow and today these destinations are considered to be the oldest Greek hot springs spa towns. Another two early destinations were two seaside resorts, Kyllini and Faliro, where visitors could enjoy a combination of thermal and sea baths.

Nineteenth-century advertisements and announcements in the press (in magazines and newspapers) are essential primary sources for the development of these Greek resorts as well as the interests and habits of their visitors. The advertisements emphasised the low cost and suitable services that Greek spas were able to offer to their visitors. In press announcements, the renters of Greek baths and the managers of grand hotels competed with each other, as they all promised comfort and proper treatment. Advertisements also stated that hotel rooms and meals in the restaurants of Greek spas had the same price as those in Athens (Empros, 18 March 1899; Efymeris, 28 June 1890).

The advertisements frequently used phrases such as: 'rooms available for all classes and budgets' and 'the aristocracy and the people,' which promoted the inclusivity of Greek baths (Efymeris, 21 April 1884; 3 May 1884). Thus, it could be claimed that the accommodation, treatment, and entertainment in the urban space of Greek thermal and seaside resorts was not an exclusive privilege of the upper class. However, it can be concluded that the majority of visitors were middle-class people whose salary would have offered them the chance to travel to Greek spas for a few days with the family and combine their need for treatment with leisure.

\section{The Patients-Tourists in the Second Period of Development of Greek Spas (1890-1930)}

The second period of development of Greek resorts could be considered their 'heyday'. In the period of 
1890-1930 Greek spas became popular tourist destinations due to legislation that favoured the operation of luxurious grand hotels and entertainment facilities. Elefterios Venizelos' government, in light of the geographical expansion of the Greek state following the Balkan Wars, passed a great number of laws about the exploitation of thermal springs that encouraged the development of spas. In 1915, the Ministry of National Economy set up a committee to 'study the measures to be taken for the scientific and deliberate exploitation of the thermal springs.' During 1915 and 1916, a chemist, Anastasios Damvergis, also a member of the committee, wrote a series of memoranda requesting the adoption of a special law that would regulate the exploitation of thermal waters. Eventually, these requests were accepted, and the laws 1292 (Efimeris tis Kyverniseos, 13-16 April 1918) and 2188 (Efimeris tis Kyverniseos, 17 June 1920) defined that the thermal springs were owned by the State and their exploitation was transferred to the Ministry of National Economy. The thermal springs that were not being exploited on January 1,1920 , were owned by the State regardless of the ownership of the land in which they were (Law 2188, article 2). This law gave to the state the right to supervise the operation of private thermal springs and to expropriate them when appropriate (Law 2188, Article 3).

In 1922, Law 2992 facilitated the concession agreements (for a period of up to 25 years) between the state and individuals or companies in exchange for the construction of accommodation and entertainment facilities. The renters of the thermal baths of Kaiafa, Smokovo, Platistomou, Sidirokastro, Lagkada, Neo Loutraki, and Kyllini had an obligation to construct facilities of European standards within the 25-year period of the contract. According to the law, the terms of exploitation of the thermal springs were specified in the contract that was signed by the contractors and the government. The decisions for the development of the Greek baths were taken by the Ministry of Economy. The contractors were obliged to act in accordance with the ministry's instructions, and the erected buildings (hydrotherapy facilities, hotels, and clubs) would have to comply with the hygiene regulations. In the 1930s, most mineral springs had been declared public, but there were still some which were owned by individu- als, municipalities, and monasteries. However, in the late 1930s, there were some variations in the number of public and private thermal springs. Of the total of 160 registered thermal springs, only 44 were in use, and 32 of them belonged to the state, while only 12 belonged to individuals, municipalities, and monasteries (Lekkas, 1930).

During this 'heyday' period, visitors showed a particular preference for sea baths, they walked along the seafront, and they socialised in the square and at the leisure facilities (hotels, casinos, and restaurants) of Greek spas. Another important factor that increased the popularity of Greek thermal and seaside resorts was the improvement of transport. The difficult access to the baths in the previous period was a deterrent factor for Greeks and for incoming visitors. However, in the $1890-1930$ period, visitors could travel quickly and comfortably to spas from Athens and other major cities by coach, by train, or by ship.

In the late 19th century, the seaside spas Edipsos and Loutraki began gaining popularity, because they offered sea and thermal baths and accommodation facilities that were affordable to visitors of all classes and incomes. The grand hotels Thermae Sylla, Avra, Pigai, Heraklion and Istiea in Edipsos and Palmyra, as well as Akti and Avra in Loutraki, offered comfortable and luxurious accommodation to upper-class visitors, but there were rooms available for visitors and lowerincome families. The establishment of entertainment facilities also made these cosmopolitan spas an ideal destination for visitors and their families who were seeking sociability, relaxation, and rest. The members of a family who travelled to Edipsos enjoyed the sun and sea on the beaches of the spa town; they went on excursions to nearby areas, and they took walks in the countryside. They spent most of their day and night socialising in the casino which was built according to the architectural design of the casino of Berlin. The casino had separate rooms for meals, family gatherings, and dances. There was also a chat and billiard room and rooms that were suitably furnished for poker and bridge players. Apart from the relaxation and gambling that the casino offered, the public had the opportunity to watch performances and films in the cinema-theatre. There were drama and comedy 
performances performed daily, and various famous Greek playwrights of this period presented their plays to the public of Edipsos for the first time.

'Greece's Monte Carlo,' Loutraki, developed due to railway transport that was established in the last decades of the 19th century and the aftermath of the earthquakes of 1924 and 1928. The AOSK (Autonomous Organisation of Earthquake - Victims of Corinth) chaired by the bishop of Corinth Damascus was established in 1930 to help the earthquake victims. In this period, the spa town was rebuilt, and a casino and hotels were constructed. Its urban space was significantly improved with the design of parks and squares. Thus, during the interwar period, Loutraki became a cosmopolitan destination, and famous personalities from Greece and abroad visited the seaside spa town throughout the year. The casino of Loutraki was the main attraction during the winter and summer season until its closure in 1936 (Koukoulas, 2001).

In this period the remarkable work of the Service of Foreigners and Exhibitions provides insight on the profile of Greek spas visitors. This service of the Ministry of National Economy had a special department responsible for the research and operation of thermal springs. The service played an essential role in the development of Greek spas, as it carefully recorded the number of their visitors. In 1920, the first statistical analysis was conducted, and the service recorded the number of bathers in order to detect any deficiencies and to proceed to the necessary construction improvements of baths. Since then, the service published an annual statistic of the people who frequented the spas (patients, their escorts and tourists), the number of baths they were taken and the revenues that were generated (Efimeris tis Kyverniseos, 30 August 1911, 19 February 1919).

Nicholaos Lekkas, the head of the service, attributed the increase in the number of spa visitors to two main factors: The visitors (who could be called holidaymakers) in this period came from various parts of Greece and from abroad (mainly from Egypt). They were attracted by the improved leisure and accommodation facilities that Greek spas offered to them. Another factor was the economic crisis of the years 19361938 that limited the currency capacity of upper-class
Table 1 A catalogue of Patients Who Used the Public Mineral Springs of Greece in the Years 1935-1937

\begin{tabular}{lrrr}
\hline Public thermal springs & \multicolumn{3}{c}{ Number of persons } \\
\cline { 2 - 4 } & 1935 & 1936 & 1937 \\
\hline Edipsos & 2443 & 1839 & 1622 \\
Eleftheres & 932 & 947 & 1123 \\
Thermopylae & 1040 & 1081 & 1631 \\
Kamena Vourla & 2286 & 1624 & 2428 \\
Caiaphas & 2434 & 2144 & 2260 \\
Kythnos & 367 & 379 & 460 \\
Kyllini & 964 & 918 & 1217 \\
Lagadas & 3699 & 2845 & 4256 \\
Loutraki & 750 & 750 & 800 \\
Methana & 2281 & 2677 & 4257 \\
N. Apollonia & 2605 & 2409 & 1310 \\
N. Loutraki (Pozar) & 1222 & 1182 & 1199 \\
Smokovo & 3654 & 3068 & 4983 \\
Hypati & 1943 & 1617 & 1849 \\
\hline
\end{tabular}

Notes Adapted rom Lekkas (1938, p. 245).

visitors who used to prefer the European spas in the previous period. The number of patients who used the private thermal springs of Greece for the years 1935, 1936 and 1937 were 24,667, 25,917, and 22,069, respectively. The public thermal springs had 36,495, 35,219 and 42,878 patients for the years 1935,1936 , and 1937 , respectively (Table 1) (Lekkas, 1938).

According to the statistics of the year 1933, the spas that gathered the larger number of tourists from abroad were Loutraki and secondarily Edipsos. The continuous stream of people (local and foreigners) who visited the spas (mainly Edipsos and Loutraki) indicates that most of them were not patients but tourists who visited the Greek spas with their families for holidays. Apart from these two cosmopolitan resorts, Methana, Hypati, Smokovo, Lagadas, and Caiaphas had the appropriate infrastructure to host foreign tourists. The figures indicate a gradual increase in the number of visitors due to a large extent to concession agreements between the state and companies or entrepreneurs that improved that urban space of Greek thermal and seaside resorts, thereby mak- 
ing them more appealing to visitors. A characteristic example is the Caiaphas baths, which managed to triple the number of their visitors during the concession period, which lasted for twenty years (1907-1927) (Lekkas, 1923).

\section{The 'Voices' of the Public: Visitors to Greek Spas in Literary and Autobiographical Texts}

The 'voices' of Greek spas visitors and patients were documented in thank you letters, memoirs, and autobiographical novels. These texts are essential sources of oral history as they reveal the preferences and experiences of the public of Greek resorts. In their thankyou letters, patients mentioned their name, their place of origin, the time they stayed in the baths and the effect that the thermal springs had on their health. These letters were also as a means of persuasion to 'advertise' the healing properties of the baths (Damvergis, 1905).

The Greek spa towns in the last decades of the 19th century and the early 20 th century served as a source for inspiration for novelists who chose to depict the urban spaces of Greek spas and the profile of their visitors in literary texts. These texts (novels, short stories and memoirs) were often based on the experiences and the impressions that their writers had during their stay at the thermal and seaside Greek resorts. The main themes of these life-writing texts are the hope of patients for a cure, social discriminations, and the need of the public for entertainment and sociability in the leisure facilities of resorts.

The great novelist Penelope Delta met and later married by match-making her husband, Stefanos Deltas in Faliro, the popular seaside resort near Athens. She travelled with her family from Alexandria to Athens to meet Stephanos Deltas and consent (with few objections) to the marriage arranged by her family. Before their first meeting, her mother advised her to wear appropriate clothing for the occasion, which indicates the importance of public display in the public sphere of the Athenian resort (Delta, 1994). During her stay in Athens, Penelope Delta had the opportunity to dine several times in Faliro and experience herself the sociability that the bourgeois Athenians enjoyed in the resort. She met many members of the Athenian bourgeoisie in the restaurants located on the seafront of Faliro. The pier offered Penelope Delta and her company the pleasure of walking along the seaside. In such a walk on the pier, the novelist discussed the matter of her marriage with her uncle, and she was persuaded to give her consent. The eve of their engagement ended with a family dinner in a restaurant on the Faliro seafront in which she received the wishes of her relatives.

In another walk on the pier with her future husband, she had the opportunity to make a personal 'confessional' conversation with him in an attempt to become better acquainted with him. While they were conversing, she avoided looking at him, and she focused her attention on the stormy sea, which reflected the lights of the seafront. During their conversation on the pier, the pair was keeping some distance from the crowd of walkers. At the end of the night, they returned to Athens together by train (Delta, 1994).

In contrast to Penelope Delta who experienced the sociability of the popular resort from the 'privileged' position of the visitor, another renowned Greek writer, Menelaos Lountemis, spent a summer working in another famous spa town. In his autobiographical novel Kalinyxta Zoe (Goodnight Zoe) Menelaos Lountemis describes his experiences as a waiter in Edipsos. The case of the author, who found seasonal employment in the resort, is perhaps indicative of the development of the spa and its architectural transformation from a small village to a popular tourist resort. M. Lountemis uses the term tempeloupoli (lazy town) to stress the touristic aspect of Edipsos in the late 1930s. According to the author, most visitors chose Edipsos for their holidays. They frequented the beaches, and they socialised and flirted in the restaurants, cinemas and hotels located along the seafront of the spa town. In contrast, restaurant and hotel managers wanted to make a profit, and they tended to economically exploit the patients and tourists who visited Edipsos (Lountemis, 2000).

Lountemis claims in his novel that the public of the spa consisted of men and women of different classes and social discriminations were evident. The 'privileged' visitors stayed at luxurious hotels, while the people of lower incomes bathed in the public baths (the price of a bath was only 10 drachmas) and they stayed 
at smaller and cheaper hotels. The author states that in the late 1930 Edipsos was a cosmopolitan resort, since European tourists and Greeks from Alexandria spent their holidays there. Although in this period Edipsos was a destination for holidaymakers, there were still a large number of patients who hoped that the use of thermal springs of the spa town could offer them therapy. Unfortunately, their hope for a cure did not always come true. One such case was the one of an elderly patient in the novel, who hoped to walk without his crutch and he was deeply disappointed when he left the spa town holding two crutches instead of one (Lountemis, 200o)!

Another category of the public of Greek seaside and thermal resorts was the children who travelled to the baths with their family. Elias Papadimitrakopoulos (1995) describes the journey by train to the baths of Katakolo in Peloponnese from the point of view of a child in his autobiographical novel, Therma Thalassia Loutra (Hot Water Baths). When he was a child, the novelist travelled to the baths every summer with his aunt, who suffered from rheumatism. The trip to the baths was a matter of significant importance, and therefore, every year, she made all the proper arrangements. She wore her hat from Trieste (which she kept hidden the rest of the year), she cleaned her black scarf, and she put their snack in a straw basket. The sea baths were very popular in the pre-war period, as there was a special first-class ticket for the hot water baths. This ticket was granted to the ticketholders who could afford to travel in the special wagon for bathers. The first-class passengers could sit in the luxurious and comfortable straw seats. It should be noted that the novelist names the wagon 'a true sanctuary', which implies the social distinction between the privileged and poorer bathers (Papadimitrakopoulos, 1995).

\section{Conclusion}

In this paper, I have attempted to present the world of Greek thermal and seaside resorts in the two phases of Greek baths. A corpus of different primary sources provided interesting facts about the profile of Greek spas' visitors. These patients and visitors were a diverse world that consisted of people of different origin and residence, income, education, and interests. However, all of them had one goal in common: both the wealthy and the poor and the patients who visited the thermal springs of Greek resorts hoped to recover or at least find some relief. They were encouraged by their doctors to make use of the baths and, depending on their financial status; they resided for or longer periods in Greek resorts. It can be claimed that the public played a vital role in the architectural improvement of the urban space Greek spas, as the increasing demands for better medical, accommodation and entertainment facilities led to the construction of the necessary amenities, which were often of European standards.

In the first period, the public made limited use of thermal waters, and began to timidly trust the baths of Kythnos. As this 'relationship of trust' between the Greek baths and their public gradually grew stronger, other seaside and thermal spas developed. At the end of the first period, their urban space improved significantly due to the construction of luxury hotels and entertainment facilities. The first visitors came mainly from the middle strata and travelled alone or with family members. In the second period of development of Greek resorts, their heyday, a shift in the profile of visitors was observed. As statistics and patients testimonies revealed, the public of Greek spas was amounted to thousands and consisted mostly of vacationers. Thus, the sea and the thermal baths, the square, the pier, luxury hotels, casinos and restaurants attracted the interest of visitors and transformed the Greek spas to popular destinations of domestic and incoming tourism.

\section{Acknowledgments}

I would like to thank Professor Tomi Brezovec and $\mathrm{Mr}$ Allan Brodie for their helpful comments on this paper. I would also like to thank Associate Professor Anna Matthaiou for her supervision and support of the thesis from which this material is drawn, and the Foundation for Education and European Culture (IPEP) for their financial assistance.

\section{References}

Damvergis, A. (1905). Ta Iamatika loutra Panagiotou D. Makri en Aedipso tis Evias. Athens, Greece: Nicholaos Tarousopoulos.

Delta, P. S. (1994). Anamniseis 1899. Athens, Greece: Ermis Publications. 
Dritsas, M. (2002). Water, culture and leisure: From spas to beach tourism in Greece during the nineteenth and twentieth century. In S. Anderson and B. Tabb (Eds.), Water, leisure and culture: European historical perspectives (pp. 193-208). Oxford, England; New York, NY: Berg Publishers.

Kandylis, I. (1981). Skapaneis ton thetikon epistimon kata ton 19 aiona. Viomixaniki Epitheorisis, 49, 565-569.

Kardamitsi-Adami, M. (2001). Xenodoxeia loutropoleon. Iamatika Loutra-Epta Imeres Kathimerinis, 24(6), 24-27.

Koukoulas, A. (2001). To kosmopolitiko Loutraki. Iamatika Loutra-Epta Imeres Kathimerinis, 24(6), 18-19.

Landerer, X. (1850). Perigrafi ton en Kythno, Aidipso kai Ypati iamatikon ydaton. Athens, Greece: Konstantinos Antoniadis.

Lekkas, N. (Ed.) (1923). Caiapha - Iamatikai Pigai. Athens, Greece: Ministry of National Economy, Service of Foreigners and Exhibitions.

Lekkas, N. (1930). Deltion Iamatikon Pigon. Athens, Greece: Ministry of National Economy, Service of Foreigners and Exhibitions.

Lekkas, N. (1938). Ai 750 metallikai pigai tis Ellados. Athens, Greece: N.p.

Lountemis, M. (200o). Kalinyxta Zoe. Athens, Greece: Ellinika Grammata.
Ministry of the Interior. (1845). Ottonian Record (File 2). General State Archives of Athens, Athens, Greece.

Ministry of the Interior. (1847). Ottonian Record (File 3). General State Archives of Athens, Athens, Greece.

Ministry of the Interior. (1848). Ottonian Record (File 4). General State Archives of Athens, Athens, Greece.

Ministry of the Interior. (1851). Ottonian Record (File 5). General State Archives of Athens, Athens, Greece.

Ministry of the Interior. (1861). Ottonian Record (File 8). General State Archives of Athens, Athens, Greece.

Ministry of the Interior. (1864). Ottonian Record (File 10). General State Archives of Athens, Athens, Greece.

Papadimitrakopoulos, E. (1995). Therma thalassia loutra. Athens, Greece: Nefeli Publications.

Varella, E. (2001a). I fimismeni Aidipsos. Iamatika LoutraEpta Imeres Kathimerinis, 24(6), 20-21.

Varella, E. (2001b). Oi loutropoleis stous neoterous xronous. Iamatika Loutra-Epta Imeres Kathimerinis, 24(6), 9-17.

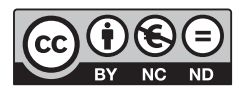

This paper is published under the terms of the Attribution- NonCommercial-NoDerivatives 4.0 International (CC B Y-NC-ND 4.0) License. 


\title{
Leisure and Commerce: Seafront Rivals in England's First Seaside Resorts
}

\author{
Allan Brodie \\ Historic England, Partnerships Team West, United Kingdom \\ allan.brodie@historicengland.org.uk
}

During the first half of the 18th century, the earliest seaside resorts were created in England in small coastal towns that had previously made their living as commercial and fishing ports. Today many seaside resorts are still co-located with ports, ranging from small, quaint fishing and leisure harbours to major container and ferry ports. In most towns, industrial places of work are in areas near the periphery or where the edge of the town was located when the factories or mills were being created in the 18th and 19th centuries. However, the harbour inevitably lies at the heart and on the front of a settlement that might become a seaside resort, and often this aspect of their story has continued alongside the new leisure industry that has come to dominate their identity. Therefore, this could lead to conflicts over time between polite society and the commercial realm, and respectable visitors and the men and women servicing the harbour and its shipping. Over 300 years, the detailed geographical and economic relationship between leisure and commerce on seafronts has evolved, and new arrangements are being reached as visitor numbers have increased and as commercial facilities have expanded. This paper will consider a number of 18thcentury English and Welsh ports that pioneered sea bathing and seaside holidays. Today, some are seaside resorts, some are purely ports, and a small group have managed to negotiate a more or less uneasy relationship between these two apparently conflicting functions

Keywords: leisure, commerce, seaside resorts https://doi.org/10.26493/2335-4194.12.13-22

\section{The First Resorts: Changing Fortunes}

By the mid-18th century, a number of small coastal towns were beginning to be transformed into seaside resorts, a consequence of the arrival of visitors seeking to bathe in the sea for the benefit of their health. At the forefront of this process was Scarborough, which had been a popular spa town since the 1620 s and therefore already had all the entertainment facilities that spa, and later seaside, visitors would require. Initially, these facilities were contained within existing buildings in the historic town that had developed on the slope above and behind the harbour. Scarborough's harbour, which was home to a fishing fleet and ship- building, also served as a port for a growing number of vessels that were transporting coal from northeast England to London. During the 1730 a wealth of documentary material, including an early guidebook, miscellanies of poetry celebrating the town and sea bathing, scientific texts, and Setterington's wonderful panoramic view of the town, clearly demonstrate that sea bathing was a prominent new factor in identity of the town (A Journey from London to Scarborough, 1734; The Scarborough Miscellany for the Year 1732, 1732; The Scarborough Miscellany for the Year 1733, 1733; The Scarborough Miscellany for the Year 1734, 1734; Shaw 1734, 1735; Setterington, n.d.). 


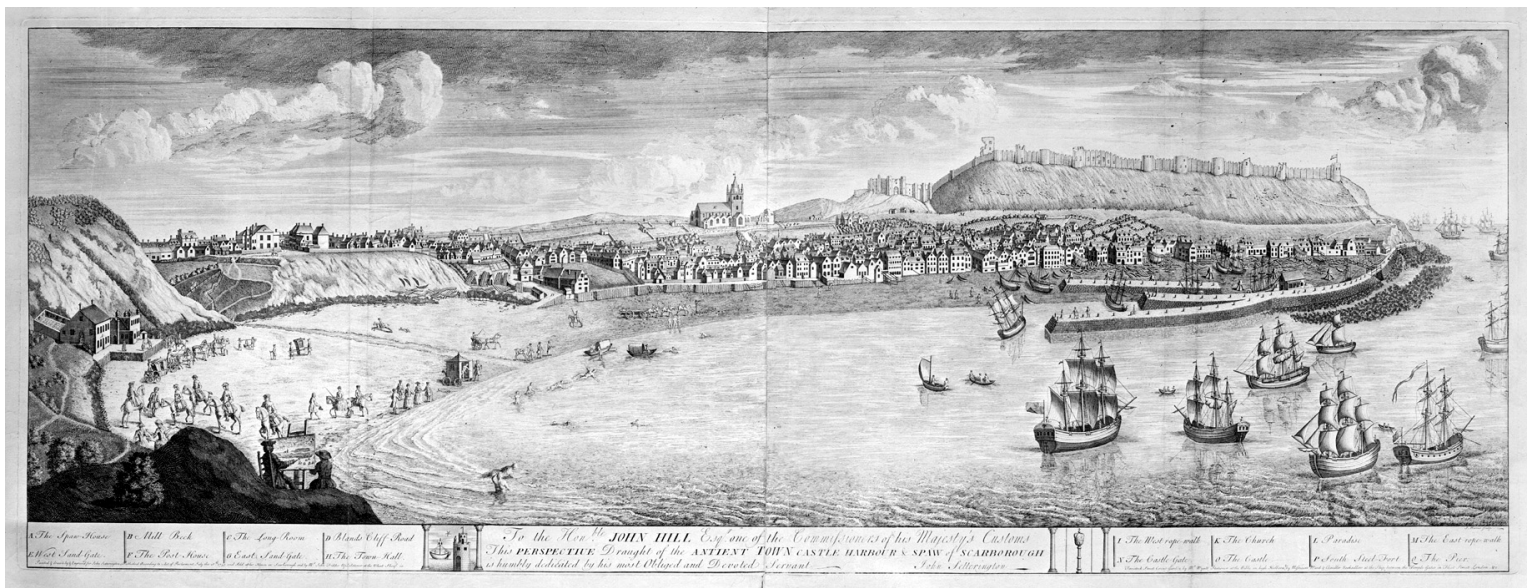

Figure 1 John Setterington, View of the Antient Town, Castle, Harbour, and Spaw of Scarborough 1735 (reproduced with permission from Historic England, cc 8o/oo145)

At Brighton and Margate, the central narrative of their history in the first half of the 18th century is that the new fad for sea bathing came to the rescue of these failing coastal towns. During the first half of the 18th century, Brighton was a small, struggling, seafaring, and fishing community with no harbour, its boats being drawn up on to the beach (Berry, 2005, pp. 2$6,10-11)$. The cessation of fishing in the North Sea, prompted in part by the erosion of the town's foreshore, led to long-term economic decline and a reduction in population (Walton, 1983, p. 48; Borsay, 2000, p. 788). In the first edition of Reverend Lewis' book on the history of the Isle of Thanet published in 1723, he described a struggling fishing industry that was heavily impacting Margate's economy, but by 1736 the situation had worsened with some fishermen having given up fishing due to suffering from poor catches in the North Sea (Lewis, 1736, p. 33). These two examples contrast with Scarborough, where the expansion of the coal industry led to significant investment in the town's harbour and increasing prosperity from the commercial part of its economy. They also make an interesting contrast because, unlike Scarborough with its pre-existing tourist market due to its spa, Brighton and Margate had to rapidly establish the range of entertainment facilities expected by visitors. Local entrepreneurs, often innkeepers and doctors, were beginning to make available bathhouses, circulating li- braries, theatres and assembly rooms at these, and other, coastal towns for a growing number of aristocrats and gentry seeking to be part of the resort's leading social circle as well as attempting to improve their health. The character of this new clientele, who were wealthy, sophisticated, metropolitan, well-dressed visitors accustomed to luxury, must have been in marked contrast to the population of these first resorts, small, provincial working towns or, as John Byng snootily described them, 'fishing holes' (Andrews, 1934, p. 87). In the early 18th century, John Macky saw Margate as 'a poor pitiful Place' and Revd Lewis in 1736 recorded that the town was 'irregularly built, and the Houses generally old and low' (Macky, 1714, p. 50; Lewis, 1736, p. 123). These ports that were adding a resort function had unpretentious buildings set in small plots separated by narrow streets, and the buildings were predominantly vernacular in style and materials. Something of the atmosphere of these proto-resorts can still be experienced in the old town at Margate, in the Laines, the original part of Brighton and behind the harbour at Scarborough. Although they were being favoured for sea bathing, their orientation, despite the presence of harbours, was not primarily towards the sea, and it was still common for buildings to be facing inland rather than seawards.

Margate and Brighton demonstrate an almost total shift from an economy dependent on the sea for 


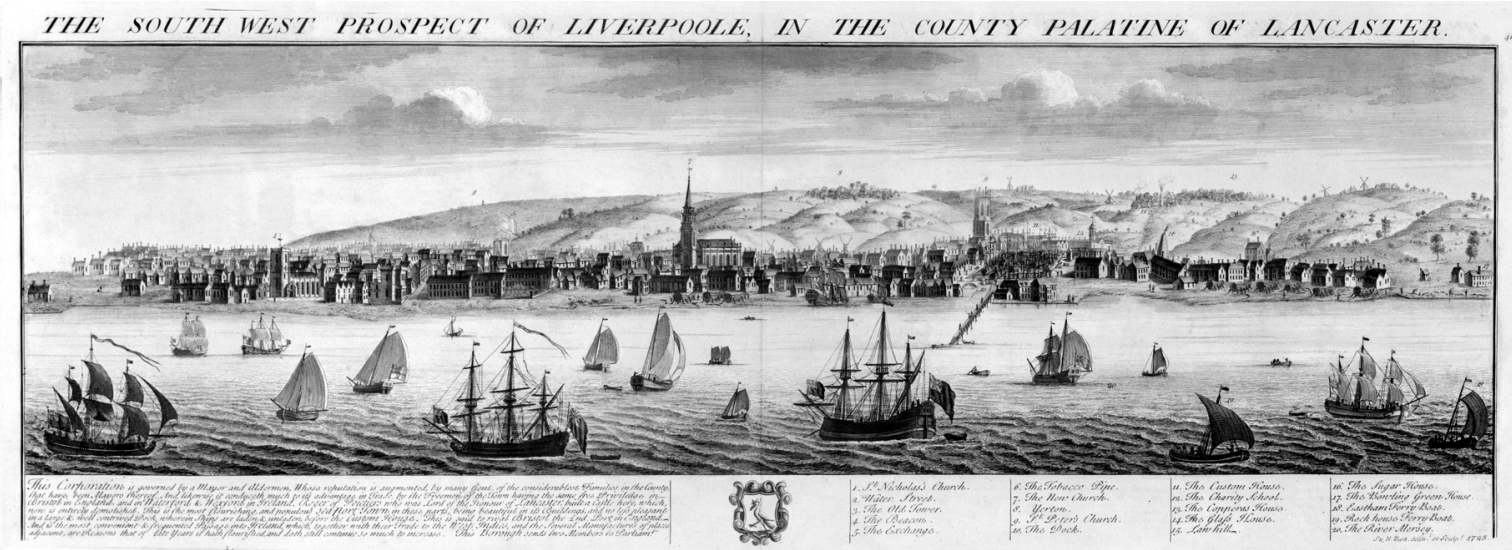

Figure 21728 Engraving by Samuel and Nathaniel Buck Entitled the South-West Prospect of Liverpoole (reproduced with permission from Historic England, в в 86/03830)

commerce and fishing to one focused on leisure by the end of the 18th century. Moreover, by the 19th century, the seafront of these towns was being recast with new buildings that were now facing the prized sea view. At other early seaside resorts, the initial commercial dimension of the original coastal towns has continued to the present day. For instance, Scarborough and Weymouth successfully combine busy working harbours with entertaining holidaymakers, though the size of the harbour and the scale of the commercial economy has not grown nearly as quickly as the leisure industry. At Hastings, a more or less uneasy truce exists between the traditional beach-launched fishing fleet and the encroaching seafront amusements and accommodation desired by tourists.

\section{Liverpool: An Early Seaside Resort?}

Inevitably, anyone considering the origins of the seaside resort will concentrate their efforts on existing resorts, plotting the shift from commerce to leisure, and examining the territorial and economic tensions that exist between two more or less incompatible functions. There is also a definite reorientation of these early seaside resorts from a geographical focus on the harbour and the town centre to the seafront and the sea view. England's rich heritage of seaside resorts has some settlements that can trace their roots back to historic coastal ports and some are still more or less active today. However, there were a handful of Georgian 'seaside resorts' that have followed a different path, shedding their initial seaside, seafront leisure activities as the commercial dimension of these towns expanded.

At the beginning of the 18th century, many early resort facilities were available at Liverpool, a city now regarded as an international port rather than a seaside resort. An urban bathhouse existed during the first decade of the 18th century, and a riverfront bathhouse was depicted in an engraving in 1728 at the edge of the town as it existed at that date. There were probably primitive bathing machines (cart-like contraptions to take bathers into the sea), and updated versions of these facilities were still in use in the early 19 th century. As well as opportunities for sea bathing, Liverpool offered the range of facilities required by the clientele of a rapidly-growing port, but these would have also catered for any visitors seeking to bathe in the sea, a function obscured by its later success as a port.

In 1673 Liverpool had around 1,500 inhabitants, living in a town that consisted of only seven main streets covering a mere 300 metres from north to south and spreading a similar distance inland from the waterfront (Chalklin, 1974, pp. 98-100; Sharples \& Stonard, 2008, pp. 3-4). In 1680, Daniel Defoe described 'a large, handsome, well built and encreasing or thriving town;' ten years later 'it was much bigger than at my first seeing it, and, by the report of the Inhabitants, 
more than twice as big as it was twenty Years before that' (Defoe, 1968, pp. 664-665). By 1700, its population was 5,145; twenty years later it had more than doubled to 11,833 , and by the beginning of the 19 th century it had grown to more than 80,000 (Chalklin, 1974, p. 20; Enfield, 1773, p. 28; Mitchell, 1962, p. 24). Liverpool moved during the 18 th century from being a small provincial town to being the second largest town in England (Chalklin, 2001, p. 79). This rapid growth was in large measure due to its location; like Bristol, it was convenient for the Atlantic trade in slaves, sugar, textiles and tobacco, but it also had a substantial hinterland that expanded rapidly during the 18th century due to the Industrial Revolution (Porter, 1982, pp. 199200; Chalklin, 1974, pp. 19-20, 49-51; Ascott, Lewis, \& Power, 2006, p. 16; Longmore, 1989, pp. 116-146, 117119). In 1709, 374 ships brought in 14,574 tons of cargo and 334 exported 12,636 tons, but by 1771 this had risen to 891 ships importing 66,656 tons and 1,024 exporting 83,798 tons (Enfield, 1773, p. 67). The Old Dock, the first enclosed, commercial maritime dock in the world, was completed in 1719, and by the end of the 18 th century the riverfront was dominated by a mile of docks (Ritchie-Noakes, 1984, p. 19; Ascott et al., 2006, p. 14; Longmore, 1989, pp. 120-122).

With a rapidly growing population and increasing commercial activity, Liverpool also began to expand its civic facilities including a new custom house built in 1721-1722 and an ambitious new exchange complete with lavish ballroom that was erected in 17491754 (Rideout, 1927, pp. 5-6, 3-73; Borsay, 1991, pp. 109, 157; Sharples and Stonard, 2008, p. 7). New entertainment facilities included walks and pleasure gardens, a purpose-built theatre that opened in 1772 and by the end of the 18th century, there was a Public Concert Room (Moss, 2007, pp. 125-126, 128-129; Brodie, 2012, pp. 63-76, 66-67). The 1766 Liverpool Directory listed a range of professions and facilities that would be expected in a major port, but also in a nascent seaside resort (Liverpool's First Directory, 1987). There were booksellers and stationers providing services similar to circulating libraries, innkeepers and coffee-house proprietors, and tradesmen providing luxury services for people of wealth. This infrastructure of leisure evolved to cater to the prosperous port, but these were also the type of facilities that were fundamental to the development of seaside resorts in the 18th century. However, proof that Liverpool was more than just a growing port, with entertainments for mariners, merchants and residents, is provided by its history of sea-bathing facilities.

The first reference to sea bathing in the vicinity of Liverpool occurs on 5 August 1708 in the diurnal of the local landowner Nicholas Blundell: 'Mr Aldred \& I Rode to the Sea \& baithed ourselves [...] it was extreamly hot as were also the two preceding days, the lick hardly ever known at this time in these parts' (Tyrer, 1968, p. 181). This reference appears six years after his diary begins, suggesting that sea bathing was still only an occasional and novel activity. Blundell seems to have bathed because it was hot, but a year later the sea was being used for medical reasons: 'I went part of the way towards the Sea with my Children but turned back, my Wife \& Dorothy Blundell went with them, they were put into the Sea for some out breacks' (Tyrer, 1968, p. 225). The Blundells probably visited the stretch of coast nearest their house, possibly Crosby Beach, where Antony Gormley's atmospheric 'Another Place' has become a modern place of pilgrimage.

At the beginning of the 18th century, Liverpool had an urban bathhouse on the south side of the Pool on the road lying to the south of where the Old Dock would be built (Touzeau, 1910, pp. 358-359, 398). A second bathhouse is mentioned in a 1708 rate book, 'ye bagniall' being in the heart of the rapidly expanding town, probably at the bottom of Water Street, on the riverside beside the Custom House (Peet, 1908, pp. 55-56). However, the first reference to organised sea bathing, which would not have been in the heart of the town, occurs in the early 1720s. On 1 August 1721 Blundell wrote that: 'Pat: Acton lodged here, he came with an Intention to stay some time to Baith in the Sea, I went with him to the Sea side to shew him what Conveniency there was for him.' The entry for the following day reads: 'I went with Pat: Acton to Leverpoole \& Procured him a Place to Lodg at \& a Conveniency for baithing in the Sea' (Tyrer, 1972, p. 52). 'Conveniency' is being used for something that has not yet acquired a name and Blundell used the term to refer to some- 


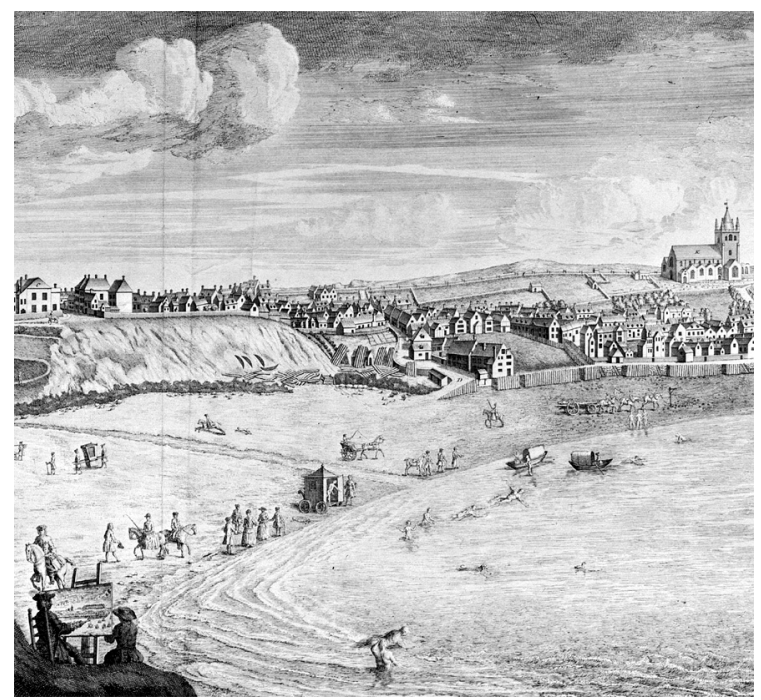

Figure 3 Detail of Sea Bathing from John Setterington, View of the antient Town, Castle, Harbour, and Spaw of Scarborough 1735 (reproduced with permission from Historic England, Cc 8o/oo145)

thing to aid bathing. A similar use of the word appears in 1735 referring to sea bathing at Scarborough: 'the Ladies have Guides, Rooms, and Conveniences for it [sea bathing], under the Cliff' (Shaw, 1735, pp. 35-36). In the same year, John Setterington's view of Scarborough depicts a figure emerging from what appears to be a primitive bathing machine, and this seems to be the only 'convenience' to which Shaw can be referring.

Blundell's companion, Father Acton, appears to have been using some form of primitive bathing machine, which was probably available to the north of the docks where there was a waterfront bathhouse by the 1720 s. A small rectangular building labelled 'Bath,' divided into two sections, presumably for male and female bathers, is depicted on a map by John Eyes in 1765, at the left (north) side of the map. ${ }^{1}$ The same arrangement appears in 1785 and $1796 / 1797$ editions of maps, but the building disappeared with the construction of the Princes' Dock, which opened in 1821 (Ritchie-Noakes, 1984, p. 43; Jarvis, 2014, p. 54). Frus-

\footnotetext{
${ }^{1}$ Liverpool's 18th-century maps are reviewed in StewartBrown (1911, pp. 143-174).
}

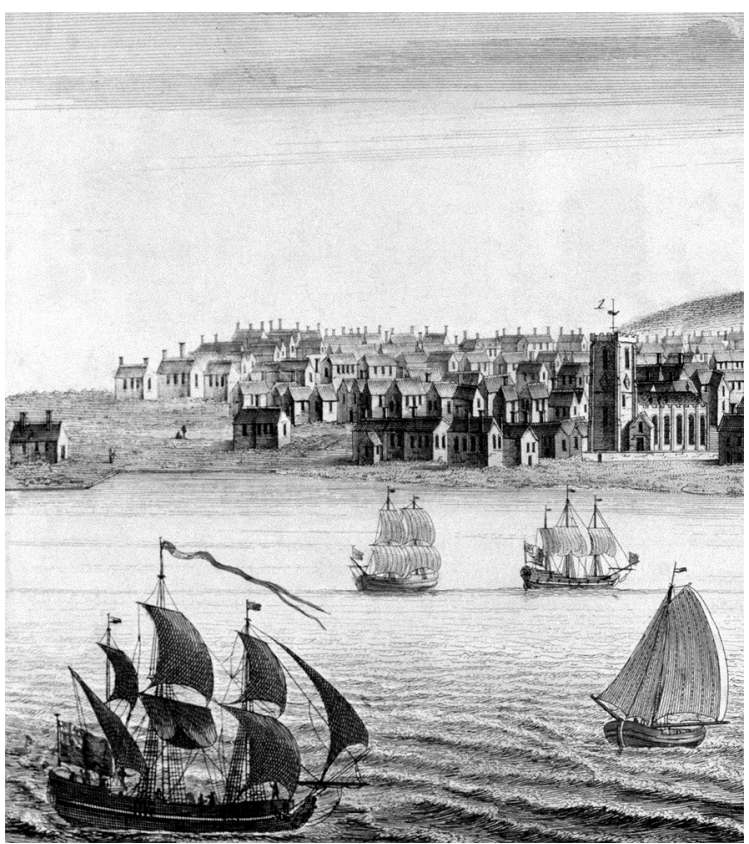

Figure 4 Detail of Bathhouse in 1728 Engraving by Samuel and Nathaniel Buck Entitled the South-West Prospect of Liverpoole (reproduced with permission from Historic England, в в 86/o3830)

tratingly, Chadwick's map of 1725 does not cover this area, as if it was still largely or wholly undeveloped, and the southern viewpoint of a 1725 painting of the town means that a distant bathhouse could not be seen (Tibbles, 2003, pp. 21-25). However, the building does appear at the far left-hand side of the 1728 engraving by Samuel and Nathaniel Buck entitled the SouthWest Prospect of Liverpoole (Buck \& Buck, 1728) which shows the river frontage of the rapidly expanding town (Figure 4). ${ }^{2}$

A small, rectangular building is shown standing on its own beside the river in the position of the bathhouse on the 1765 and subsequent maps. Its slightly odd size and shape, including the number and position of the chimneys and its tall proportions as depicted by

${ }^{2}$ On 26 August 1727 Nathanial Buck visited the Blundell's house to try to sell prints: 'Nathaniall Buck came to see if I would subscribe to his Proposalls for Publishing the perspective Views of some old Abbies and Castles \&c: in Lancashire, Chesshire and Darby-Shire' (Tyrer, 1972, p. 221). 
the Bucks are confirmed in a view of the bathhouse as it existed at the end of the 18th century. The bathhouse continued in use until the early 19 th century but was apparently demolished in 1817 to make way for the Prince's Dock as the riverfront began to become increasingly dominated by docks and other commercial structures. An 1814 map included the site of Prince's Dock with a faint rectangular shape labelled 'Baths', as if its future removal was expected, while a map published in the following year shows the baths as if intact but with the line of the dock wall running through them. ${ }^{3}$

As the port grew during the 19th century, bathing was instead relegated to the suburbs and beyond. A bathhouse was open by the 1820 s at 1 Neptune Street, which was further to the north, lying inland from East Waterloo Dock (Gore's General Advertiser, 6 March 1823). Waterloo and Crosby, where the Blundells had bathed at the beginning of the 18th century, became increasingly popular. At Southport, a bathing house was built in 1792 by William Sutton, followed by his hotel in 1798 and a range of other facilities accrued gradually during the early 19th century (Bailey, 1955, pp. 29, 34; Glazebrook, 1862, pp. 59-64; Alsop, 1832, p. 39 ; Robinson, 1848, p. 25 ). In the course of the 19th century, Southport became a favourite place for people from Liverpool to enjoy the sea and a place for wealthy businessmen to live. However, there was still a need for baths to serve Liverpool and people using the docks and a new bathhouse opened on the river in front of George's Dock in 1828 in a monumental classical structure. This was demolished in 1906 during the redevelopment of the Pier Head (Newlands, 1856, p. 10; Calvert, 1987, pp. 117-136, 121).

\section{Modern Ports - Old Resorts}

As well as Liverpool, there are other major cities where sea bathing was once a significant presence on the seafront but has now been driven to the peripheries of the settlement or beyond. In a letter dated 'Saturday 9 August 1755,' 'Mr H' wrote that 'Portsmouth has been now, for many months, the rendezvous of the fashionable world; every gay young man of fortune,

\footnotetext{
${ }^{3}$ Thomas Kaye's Map of 1815 in Gregory et al. (2014, p. 95).
}

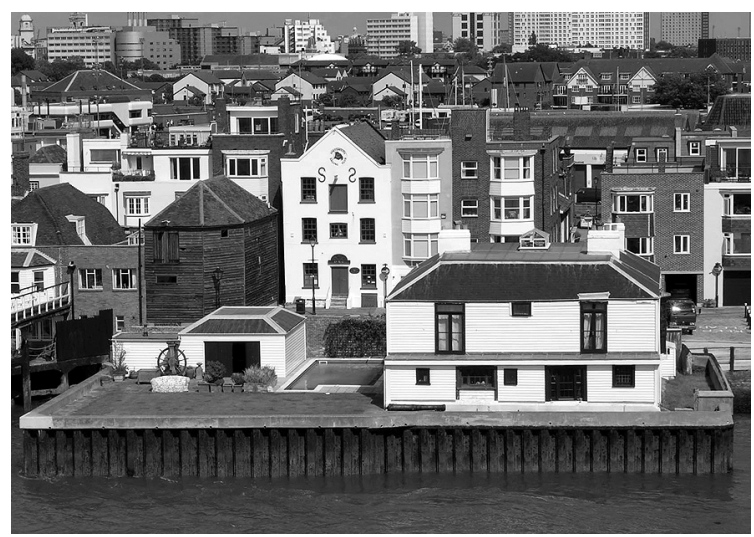

Figure 5 Quebec House, Portsmouth from Passing Car Ferry (photo by Allan Brodie)

and woman also, in their circle of joyous amusements, took a transient view of it' (Mr. H., 1757, p. 16). The reason for this seems to have been a nascent sea bathing culture in the town, rather than at nearby Southsea where resort functions developed during the 19th century. Remarkably, Portsmouth still retains its Georgian bathhouse near the docks. Quebec House was built in 1754 and was mentioned in the same year by $\mathrm{Dr}$ Richard Pococke: 'The town of late has been resorted to for batheing and drinking the sea-water, and they have made a very handsome bathing-house of wood, at a great expence, with separate baths and apartments for men and women' (Cartwright, 1888, p. 114). In 1755, Archibald Maxwell waxed lyrically about this new facility in a footnote to a poem: 'The open and close Baths begun and finish'd by the worthy Corporation and principal Inhabitants, at their own private Expence; which for Elegance of Structure, and Salubrity of the Water, are no where exceeded' (Maxwell, 1755, p. 15). The incoming tide was used to fill four baths, two of which were apparently large enough for swimming (Riley, 1972, p. 5; Lloyd, 1974, pp. 49, 51) (Figure 5).

This bathhouse still stands near the docks and can be seen most clearly from passing car ferries. While this location may seem strange, a quayside position was also used for Weymouth's first bathhouse in the 18 th century, despite the town having a long beach and seafront (Brodie, Ellis, Stuart, \& Winter, 2008, p. 12). The same letter written by ' $\mathrm{Mr} \mathrm{H}$ ' in 1755 also recorded 
that: 'In this reign of saltwater, great numbers of people of distinction prefer Southampton for bathing; but you agree with me, that the bathing-house is not comparable to that of Portsmouth: not only as being smaller, and uncovered, but here is no water, except at certain times of the tide; whereas at Portsmouth one may always bathe' (Mr H., 1757, p. 25). Southampton had mineral springs and three bathhouses developed beside its two quays as the town only had a muddy foreshore rather than a beach (Temple Patterson, 1966, p. 39; Hembry, 1990, p. 242). A 1771 map shows bathing houses on the water's edge, beside the West Quay with the 'Long Room' behind, while an 1802 map shows a similar arrangement along with Goodman's Baths further to the south. Although the dockside may not seem a particularly salubrious or glamorous location, in 1750 George II's son, Frederick Prince of Wales, bathed in the town while staying nearby (Temple Patterson, 1966, p. 39). Dr Pococke, who visited in 1757, noted that: if it had not of late been much frequented for bathing and drinking the salt waters they would have had very little commerce, except among themselves' (Cartwright, 1888, p. 242). Count Friedrich von Kielmansegg, who visited England in 1761-1762, described how: 'Many people come here every year, partly for sea-bathing, partly by order of their physicians, who consider the air of Southampton to be the healthiest in all England' (von Kielmansegg, 1902, p. 270). Baths survived on the quayside until the 1830 s when the main bathing establishment was converted into the 'Dock-house' (Freeling, 1839, p. 51). Like Portsmouth and Liverpool, the growing scale of the commercial dimension of the town displaced sea bathing to further afield.

Other, smaller ports also managed the dual function of being a commercial port and a seaside resort for a time. Dover, although primarily a port of transit, provided many features expected at a seaside resort (Figure 6). It hosted visitors during the summer who used its hot baths and bathing machines, as well as its circulating libraries and its new assembly rooms and theatre (A Guide to all the Watering and Sea-Bathing Places, 1810 pp. 225-229). Snargate Street running along the base of the cliffs contained facilities for visitors including circulating libraries, a theatre and lodging houses,

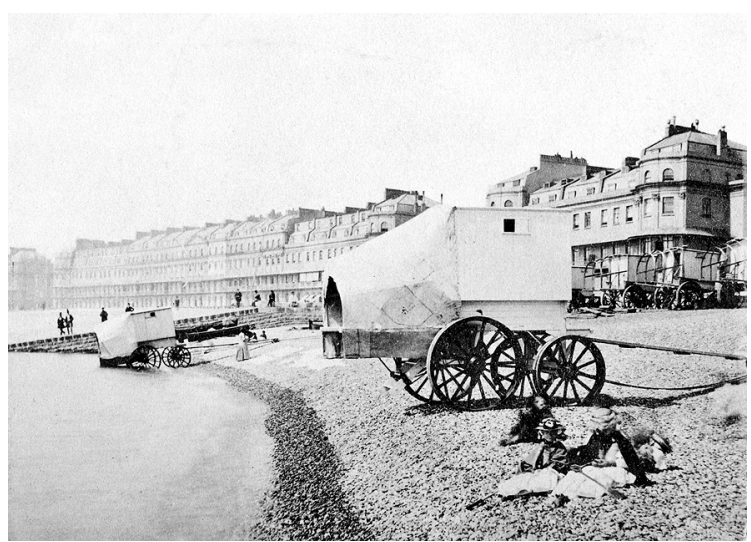

Figure 6 Early Photograph of Bathing Machines on the Beach at Dover (reproduced with permission from Historic England, в в 88/03995)

while a row of early 19th century houses survive nearer the modern ferry terminal. During the 19th century, bathing machines are shown in photographs on the beach that lies within the harbour and people still regularly swim in this location. Harwich, a small port in the 18th century, also had private baths filled by the tide and by 1810 the town was offering bathing machines (A Guide to all the Watering and Sea-Bathing Places, 1810, p. 261). From 1766, a 'mixture of county, naval and Plymouth families' in search of a colourful social life could use that town's Long Room and the accompanying tepid bath on the shore of Mill Bay (Gill, 1993, p. 193; Rolf, 2011, p. 51). By the early 19th century Swansea was attracting sea bathers despite the pall of copper smoke that apparently hung over the periphery of the town (Miskell, 2011, pp. 113-125, 115-117). It had hot and cold sea water baths, libraries, and an assembly room and theatre - the key pieces of infrastructure for a successful resort.

\section{Conclusion}

At Swansea, the construction of commercial docks in the mid-19th century on the foreshore traditionally used for sea bathing meant that this leisure activity shifted out of the town to the western end of Swansea. Moreover, around Britain, there are major towns where, like Swansea, the centre is now dominated by commercial activity and leisure access to 
the sea has been displaced to the edge of the settlement or to a largely self-contained twin settlement. In the case of Portsmouth, Southsea serves as its twin with extensive sea bathing and leisure facilities. Waterloo, Crosby and further away Southport now meet the leisure demands of Liverpudlians on the east bank of the Mersey, while on the Wirral, New Brighton remains a popular place for a day out after a trip on the legendary ferry or through the tunnel beneath the river. Dover, now dominated by its ferry terminal, still attracts some people to bathe in the sea, though many appear to be waiting for a ferry or preparing to swim across the English Channel. Furthermore, a modern creation, Port Talbot in South Wales, has the adjacent Aberavon where the residents can enjoy access to the sea against the backdrop of the steelworks, much as the inhabitants of Swansea two centuries ago bathed under clouds from the nearby copper works.

While there is now a geographical and economic need to separate large-scale commercial and industrial activity from leisure pursuits, this was far from the case during the 18 th century. Although this process of separation was already underway at many coastal towns, industrial activity, including the working life of the port, was even an attraction for some visitors. For instance, in the diary of his holiday in 1829 Daniel Benham described a visit to the gasworks at Margate and seeing the steam engine at Ramsgate that opened the harbour sluices (Whyman, 1980, pp. 185-225, 191, 197). Moreover, diaries and guidebooks regularly refer to a wide range of industrial, commercial, and institutional sites that members of the public might enjoy visiting, ranging from textile mills and breweries to prisons and active military fortifications. In modern parlance, they were indulging in a form of dark tourism, the difference being that in the 18th century these tourists were examining living phenomena rather than staring at relics of the past. Today, holidaymakers at seaside resorts with active harbours often pass the time watching the boats and fishermen. However, it is unlikely that people driving past the rear of the Liver Building on Liverpool's waterfront realise that they are passing over the site of the town's brief life as a seaside resort during the 18th century. Nor do many travellers on ferries to France realise that, as they are leaving Portsmouth, they are passing by a Georgian bathhouse, a relic of the town's previous life of leisure.

\section{References}

A journey from London to Scarborough. (1734). London, England: Caesar Ward and Richard Chandler.

A guide to all the watering and sea-bathing places. (1810). London, England: N. p.

Alsop, W. (1832). A concise history of Southport, etc. Southport, England: William Alsop.

Ascott, D. E., Lewis, F., \& Power, M. (2006). Liverpool 166o1750: People, prosperity and power. Liverpool, England: Liverpool University Press.

Bailey, F. A. (1955). A history of Southport. Southport, England: A. Downie.

Berry, S. (2005). Georgian Brighton. Chichester, England: Phillimore \& Co.

Borsay, P. (1991). The English urban renaissance. Oxford, England: Clarendon.

Borsay, P. (2000). Health and leisure resorts 1700-1840. In P. Clarke (Ed.), The Cambridge urban history of Britain 1540-1840 (pp. 775-804). Cambridge, England: University Press.

Brodie, A. (2012). Liverpool and the origins of the seaside resort. The Georgian Group Journal, 20, 63-76.

Brodie, A., Ellis, C., Stuart, D., \& Winter, G. (2008). Weymouth's seaside heritage. Swindon, England: English Heritage.

Buck, S., \& Buck, N. (1728). South-West Prospect of Liverpoole. British Library Maps (K.Top.18.76.a), The British Library, London, England.

Calvert, J. (1987). 'The means of cleanliness:' The provision of baths and wash-houses in early Victorian Liverpool. Transactions of the Historic Society of Lancashire and Cheshire, 137, 117-136.

Cartwright, J. J. (Ed.) (1888). The travels through England of Dr Richard Pococke. London, England: Camden Society.

Chalklin, C. W. (1974). The provincial towns of Georgian England: A study of the building process, 1740-1820. Montreal, Canada: McGill-Queen's University Press.

Chalklin, C. W. (2001). The rise of the English town, 16501850. Cambridge, England: Cambridge University Press.

Defoe, D. (1968). A tour thro' the whole island of Great Britain (Vol. 2). London, England: Frank Cass.

Enfield, W. (1773). An essay towards the history of Leverpool. London, England: Printed for J. Johnson.

Freeling, A. (Ed.) (1839). Picturesque excursions; Containing 
upwards of four hundred views, at and near places of popular resort. London, England: Ackermann \& Co.

Gill, C. (1993). Plymouth: A new history. Tiverton, England: Devon Books.

Glazebrook, T. K. (1862). A guide to Southport, North Meols in the county of Lancaster: With an account of the places in the immediate neighbourhood (2nd ed.). London, England.

Gregory, R. A., Raynor, C., Adams, M., Philpott, R., HowardDavies, C., Johnson, N., Hughes, V., \& Higgins, D. A. (2014). Archaeology at the waterfront 1: Investigating Liverpool's historic docks. Lancaster, England: Oxford Archaeology North.

Hembry, P. (1990). The English spa 1560-1815: A social history. London, England: Athlone.

Jarvis, A. (2014). Liverpool: A history of 'The Great Port.' Liverpool, England: Liverpool History Press.

Lewis, J. (1736). The history and antiquities, as well ecclesiastical and civil, of the Isle of Tenet, in Kent. London, England: J. Lewis.

Liverpool's First Directory. (1987). Liverpool, England: Scouse Press.

Lloyd, D. W. (1974). Buildings of Portsmouth and its environs. Portsmouth, England: Portsmouth City Council.

Longmore, J. (1989). Liverpool Corporation as landowners and dock builders, 1709-1835. In C. W. Chalklin and J. R. Wordie (Eds.), Town and countryside: The English landowner in the national economy, 1660-1860 (pp. 116146). London, England: Unwin Hyman.

Macky, J. (1714-1723). A journey through England (3 vols.). London, England.

Maxwell, A. (1755). Portsmouth: A descriptive poem in two books. Portsmouth, England.

Miskell, L. (2011). A town divided? Sea-bathing, dock-building and oyster-fishing in nineteenth-century Swansea. In P. Borsay and J. Walton (Ed.), Resorts and ports: European seaside towns since 1700 (pp. 113-125). Bristol, England: Channel View Publications.

Mitchell, B. R. (1962). Abstract of British historical statistics. Cambridge, England: Cambridge University Press.

Moss, W. (2007). Georgian Liverpool: A guide to the city in 1797. Lancaster, England: Palatine.

Mr H. (1757). A journal of eight days journey from Portsmouth to Kingston upon Thames. London, England.

Newlands, J. (1856). Report on the establishment and present condition of the public baths \& wash-houses in Liverpool. Liverpool, England.

Peet, H. (Ed.) (1908). Liverpool in the reign of Queen Anne, 1705 and 1708. Liverpool, England: Henry Young.
Porter, R. (1982). English society in the eighteenth century. London, England: Allen Lane.

Rideout, E. H. (1927). The old custom house, Liverpool. Transactions of the Historic Society of Lancashire and Cheshire, 79, 141-174.

Riley, R. C. (1972). The growth of Southsea as a naval satellite and Victorian resort. Portsmouth, England: Portsmouth City Council.

Ritchie-Noakes, N. (1984). Liverpool's historic waterfront. London, England: H MsO.

Robinson, F. (1848). A Descriptive history of Southport ... on the western coast of Lancashire. London, England: Hall \& Co.

Rolf, V. (2011). Bathing houses and plunge pools. Oxford, England: Shire.

Setterington, J. (N.d.). View of the ancient town, castle, harbour, and spaw of Scarborough. British Library Maps (K.Top.44.47.b), The British Library, London, England.

Sharples, J., \& Stonard, J. (2008). Built on commerce: Liverpool's central business district. Swindon, England: English Heritage.

Shaw, P. (1734). An enquiry into the contents, virtues and uses of the Scarborough Spaw-Waters. London, England: Peter Shaw.

Shaw, P. (1735). A Dissertation on the contents, virtues and uses, of cold and hot mineral springs; particularly, those of Scarborough: In a letter to Robert Robinson. London, England: Ward and Chandler.

Stewart-Brown, R. (1911). Maps and plans of Liverpool and district by the eyes family of surveyors. Transactions of the Historic Society of Lancashire and Cheshire, 62, 143174.

Temple Patterson, A. (1966). A history of Southampton, 170o1914 (Volume 1). Southampton, England: Southampton University Press.

The Scarborough Miscellany for the Year 1732. (1732). London, England.

The Scarborough Miscellany for the Year 1733. (1733). London, England.

The Scarborough Miscellany for the Year 1734. (1734). London, England.

Tibbles, A. (2003). A new painting of Liverpool: A prospect of Liverpool about 1725. Transactions of the Historic Society of Lancashire and Cheshire, 152, 21-25.

Touzeau, J. (1910). The rise and progress of Liverpool from 1551-1835. Liverpool, England: Liverpool Booksellers Co.

Tyrer, F. (1968-1972). The great diurnal of Nicholas Blundell of Little Crosby, Lancashire (3 vols.). Chester, England: Record Society of Lancashire and Cheshire. 
Von Kielmansegg, F. (1902). Diary of a journey to England in the years 1761-1762. London, England: Longmans \& Co. Walton, J. K. (1983). The English seaside resort: A social history, 1750-1914. Leicester, England: Leicester University Press.
Whyman, J. (1980). A three-week holiday in Ramsgate during July and August 1829. Archaeologia Cantiana, 96, 185-225.

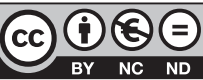

This paper is published under the terms of the Attribution- NonCommercial-NoDerivatives 4.0 International (CC B Y-NC-ND 4.0) License. 


\title{
The City and the Sea: Evolution and Transformation of a Controversial Relationship
}

\author{
Annarita Teodosio \\ University of Salerno, Italy \\ ateodosio@unisa.it
}

Over the centuries, the relationship between the city and the sea has been transformed. Diverse factors (political, economic, social, scientific) have changed the way people see the sea, gradually turning the seafront from being a place of danger into a new development opportunity. In recent years, the demolition of restrictive structures and the construction of promenades along the waterfront has marked its opening to the horizon and contributed to giving a new face to the coastal cities. In addition, the economic crisis of the 1970 led to the decline of many industrial and port areas and the subsequent abandonment of several coastal areas. Since the 1980s, a series of actions began to restore these degraded areas. The various interventions, although different in origin and design methods, had in common the desire to restore the relationship between the city and the sea and the creation of new opportunities for urban, economic, and socio-cultural growth. This study traces the critical stages of a slow and complex process of opening cities to the sea and analyses the transformations from the 19th-century historical promenade into a territorial landmark, a fulcrum of urban, economic, and tourism development. It provides, through a comparative and critical analysis of the case studies, which include famous and egregious examples such as Barcelona and Bilbao, and less known and discrete destinations such as Vigo, as well as some Italian cases, an overview of the extensive experience of abandoned and re-used port areas and suggests a reflection on the city in general. Now more than ever, cities are in search of a new identity, alternative centralities, and environmental, social, and economic sustainability.

Keywords: coastal cities, promenade, waterfront regeneration

https://doi.org/10.26493/2335-4194.12.23-30

\section{From a Place of Contemplation to an Opportunity for Development}

Between the 17th and 18th centuries, the decreasing need for coastal, military defences due to changes in political conditions ${ }^{1}$ and the spread of a landscape aes-

${ }^{1}$ The Battle of Lepanto of 1571 put an end to the so-called 'Turkish danger' and restored the Mediterranean to a climate of peace, after a period of great instability. For this reason, from the 17th century onwards, fortifications arwase con- thetic that preferred open scenery and natural environments contributed to the establishment of a new urban vision especially evident in coastal cities (Marciano, 2005). The sea was no longer perceived as a danger; it was transformed into a pleasant and sensual place for rest and recreation.

The role of the sea as the bearer of aesthetic, recre-

centrated only in strategic points and coastal cities opened up progressively on the coast. 
ational, therapeutic, and symbolic values is found in every period of the history of Mediterranean civilisations. However, the concept of the modern waterfront was born in the late 18th century, when English seaside resorts were created and organised to provide holidays (Camporesi, 1992; Corbin, 1988). This blended the contemplative Nordic spirit of escape to nature with a typical Mediterranean feeling of those communities that, for climatic reasons, are accustomed to living outdoors to enjoy the landscape, to meet people, and to see and be seen (Massa, 2005).

From that point onward, the waterfront shifted from being a simple transition between land and water and was transformed into a public space par excellence, beloved by locals and tourists. The spatial arrangements become increasingly complex and structured by new features and new functions. These are generally organised in parallel bands marked by sequences of natural (flower beds, gardens) and manufactured (benches, fountains) elements and by buildings for recreation and leisure (Balducci \& Orioli, 2006). Architectural essays resulted from the reworking of existing models (hotels, cafes, kursaal) or by new inventions (beaches used for leisure, pleasure piers) (Massa, 2005). Buildings that previously turned their backs to the sea and had their primary facades facing the city were now facing the coast.

Cities, especially those with tourist ambitions, asked the most influential engineers and architects to build monumental marine promenades and seafronts, with a strong visual impact. Between the end of the 19th century and the beginning of the 2oth century, the most famous scenic routes and walks along the coast were built, which often become the subject of literary descriptions, paintings, photographs, and even film sets (Massa, 2005, p. 13): from the elegant Promenade des Anglais in Nice, with its dream hotels and its ArtDeco architectures (Massa \& Zucchini, 2005a), to the 'exclusive' boardwalk in Atlantic City, where access was prohibited to beggars, drunks, people of colour, or the badly-dressed (Massa \& Zucchini, 2005b), to the Brighton seafront with the Victorian buildings, its piers and terraces from which visitors enjoyed spectacular views (Di Cristina, 2005). Beyond the different names that these routes take in various European countries, ${ }^{2}$ they represent 'the synthesis between the natural environment and the architectural solutions of urban monumentality' (Marsala, 2002, p. 79).

The different perception of the land-water margin as a place of leisure and meeting place for citizens and tourists consolidated and grew until the first decades of the 190os. However, the various plans for reconstruction after World War 2 did not seem to attribute due importance or respect to the coast. Along the coast and seafront, in fact, the main roads and rail arteries frequently were placed, constituting a physical and visual barrier between the city and the sea; these are focuses of an intensive urbanisation, almost always of poor quality and insensitive to environmental issues, which cannot produce architectural and urban environments worthy of their 19th-century predecessors.

Towards the end of the 2oth century, the fate of historical promenades became intertwined with disused port areas within broader and complex urban regeneration projects that impacted ever longer stretches of the coast. The industrial crisis of the 1970s and the evolution of transport and storage infrastructure entailed the reorganisation of commercial activities and the relocation of many pieces of infrastructure. Thereafter, large spaces were liberated, often in strategic locations in contact between the sea and the city, which had been previously denied or inaccessible because of the port and industrial installations. The need for transformation and re-appropriation of these urban voids also stimulated new reflections on the city in general. The seafront was no longer an equipped walk of 19th-century memory or a simple line between water and land, nature and buildings, but was becoming 'a network of places and functions, grafts and reconnections between the coast and the city, between the port and urban activities' (Carta, 2006, p. 227). There are discussions about how to organise these spaces filled with historical, social, but also economic heritage and activity. The urban centres of gravity have moved, and the presence of water has become an added value and a valuable 'card to play' for these cities to enhance their attractiveness and competitiveness (Brut-

\footnotetext{
${ }^{2}$ Passeggiata or lungomare in Italy; promenade in France; marine parade in England; paseo in Spain.
} 
tomesso, 2007). Many cities are in search of new identities and new areas of development, and the seafront becomes the fulcrum around which new urban development occurs (Teodosio \& del Caz Enjuto, 2013); it provides an excellent opportunity for growth, including economic growth (Alemany, 2006). The keen interest in the topic is demonstrated by many events, debates, research activities, and scientific publications, as well as by the birth of various associations and web sites devoted to documentation and information about the problems and the experiences of urban settlements defined by their relationship with water. ${ }^{3}$ Since the 1980 s, many various actions have taken place aimed at the physical regeneration of seafronts, at the architectural restoration of industrial heritage and/or the general reorganisation of the city waterfront, including through the creation of various functions (public, touristic, commercial, residential). San Francisco led the way: a remarkable transformation took place starting from the sea and spreading to the inland areas of the city. It was followed by other examples, including Baltimore with its Inner Harbour and the Saint Charles district, New York with Pier 17, Sydney with the Darling Harbour area, London with the Docklands area, Barcelona with Port Vell, Bilbao with the Abandoibarra area, Genoa with Porto Vecchio, and the more recent experiences of Vigo and Salerno.

\section{Spanish Accomplishments and Italian 'Promises'}

At the end of the 2oth century, in the Mediterranean countries with strong historical links to the sea, waterfront regeneration policies assumed particular importance, creating some emblematic achievements.

In Spain, in the 1980s, with the end of the dictatorship, the recovery of the coast assumed even great political value. The coast had been severely compromised by the balearizaciòn ${ }^{4}$ phenomenon and by the serious setbacks of the maritime boundary. Therefore,

${ }^{3}$ Among these, the Centro Internazionale Città d'Acqua, an association founded in Venice in 1989, to develop and promote research initiatives on different aspects of watercity relationship; RETE, an association between ports and cities; the WIN (Waterfront International Network) specialized website on the themes of the waterfront.

${ }^{4}$ A term coined in the late 1950 s to indicate urban destruction the new democratic government, which succeeded the Franco regime, decided to intervene through the promulgation of the Ley de Costas (1988). This law, which repealed previous ones, ${ }^{5}$ proclaimed the public character of the coast, removing it from the hands of private speculators and returning it to the people (Pié i Ninot, 2005). This law recognised the great strategic value of the shore, even in the economic sphere. Thereafter, thanks to shared and synergistic action by all levels of government (municipalities, autonomous regional governments, state) it triggered a process of transformation that produced solutions with high technical and economic content that became real reference models. They involved projects to regenerate the beach and the marine ecosystem using new maritime engineering techniques. ${ }^{6}$ Good quality, modern architecture has been built on the seafront, and wellequipped spaces and paths have become critical elements of the redevelopment of the waterfront (Trapero, 1988).

The transformation of Barcelona was in the context of the award of the Olympic Games (1986), new legislation, and general, widespread optimism, as well as the availability of substantial economic resources, triggering a significant process of urban renewal. Eventually, it was possible to overcome all the technical, administrative and economic difficulties that had led to the failure of previous attempts to change. ${ }^{7}$ The transfor-

implemented on the coasts of Mallorca during the Franco dictatorship. In the broadest sense, it refers to continuous and massive construction on the coast.

${ }^{5}$ Ley de Aguas $(1866,1918)$, Ley de Paseos Maritimos (1918, 1957), and Ley de Costas (1969), where the laws that favored the privatisation of the territory.

${ }^{6}$ Since the late 1970s in Spain, there has been discussion about coastal erosion. The engineer Enrique Copeiro del Villar attributed the degradation to the construction of infrastructure (marinas, especially) and to the positioning of the breakwaters that interfered in the natural dynamics of the sea and he stressed the need for 'suaves' (sweets) and noninvasive actions (Copeiro de Villar, 1978, 1980).

${ }^{7}$ The first attempt at coastal redevelopment is represented by the Plan de Ribera (1965), promoted by large businesses. The plan, much disputed and fortunately not implemented, envisaged a very dense development of residential building along the seafront. 


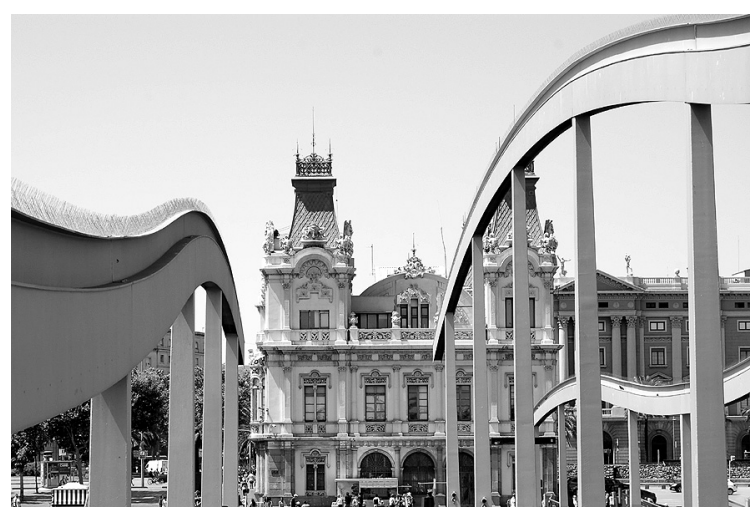

Figure 1 Barcelona, Port Vell (Photo by Author)

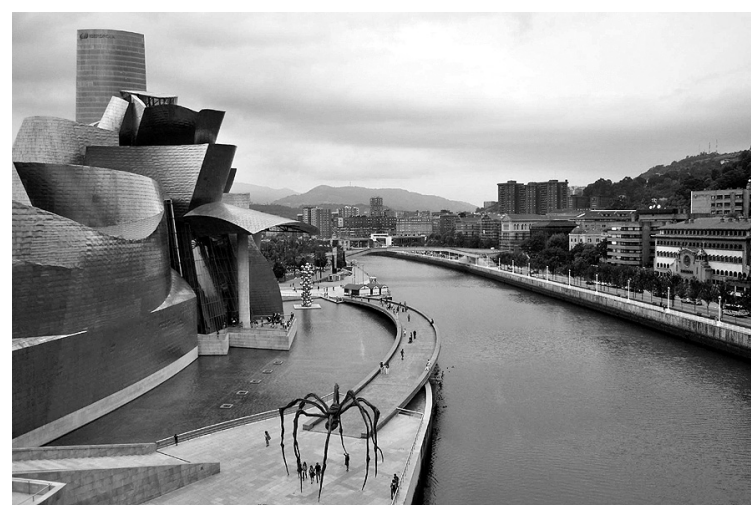

Figure 2 Bilbao, View of the Rì whith the Guggenheim Museum (Photo by Author)

centre for shipbuilding, as well as for steel production and manufacturing. Factories, warehouses, and stores occupied the entire coastline, creating an urban skyline with a purely industrial character. With the economic crisis, the changed political conditions resulting from the death of the dictator General Franco and the flooding of the River Nervion in 1983, Bilbao had to undertake a process of renewal. This time the starting point for the redevelopment was brownfield sites located on the riverfront. This required significant infrastructure projects (e.g., the relocation of the port and the railway line, the construction of a subway line along the Rìa) and two detailed plans (Plan Especial de Reforma Interior) were drawn up for the areas of Abandoibarra and Ametzola. On that latter area are the Guggenheim Museum and the Euskalduna Palace of Music and Congress; they became the two ends of the new urban route along the banks of the estuary, a fitting public space for the city (Ronzani, 2006).

A similar, but yet very different, operation was realised in Vigo between 1994 and 2004 by the architect Guillermo Vázquez Consuegra, winner of the competition 'Abrir Vigo al mar' promoted by the Consortium of the Zona Franca de Vigo. The competition was aimed at the redevelopment of the waterfront to revitalise and integrate it into the city centre. The Andalusian architect worked on a long and linear band delimited by two squares - Plaza de la Estrella east and Plaza de Berbes west. This led to the creation of an extensive public space, with pedestrian paths, gardens 


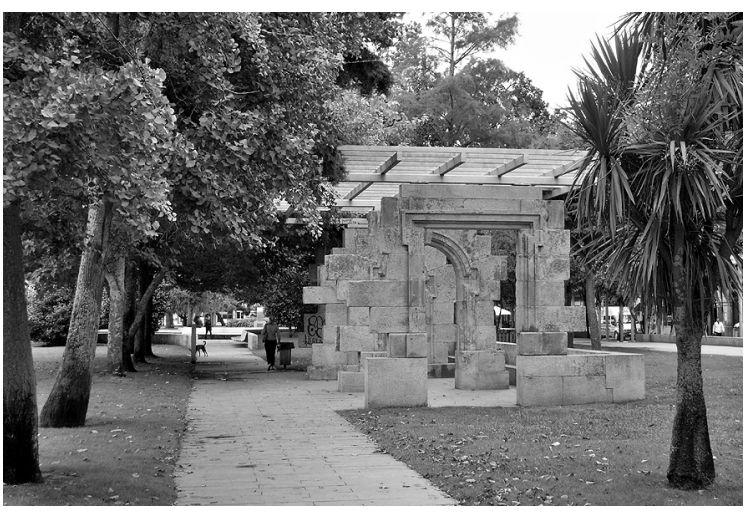

Figure $3 \quad 3$ Vigo, Waterfront designed by Guillermo Vázquez Consuegra (Photo by Author)

and fountains, large sculptures, public buildings (theatre, maritime station, shopping centre, aquarium), along with some underground infrastructure (tunnels, parking lots). He realised a high-quality project, using a stripped-down vocabulary, a skilful choice of good-quality materials (granite, galvanised steel, corten steel, white concrete for the exterior, glass), precise design, and careful execution (Vázquez Consuegra, 2008). Consuegra, with its poetic and discreet work, transformed a marginal area in a central location and opened to the sea a city with a historically consolidated industrial and port. His scheme, although using small-scale interventions compared to other celebrated cases in Spain, has been recognised as a good example of the redesign of a marine frontage for a city (Pittini, 2006).

In Italy, with its $8000 \mathrm{~km}$ of coastline, interest in the redevelopment of coastal areas is becoming increasingly important in urban policies. Since the 1990s, many coastal cities seeking to emulate the positive results of international examples have equipped themselves with planning tools based on growth forecasts expected from a renewed relationship with the sea. Unfortunately, the Italian situation is very different from the Spanish one; there are still many critical issues and conflicts that need to be solved, primarily at a bureaucratic and legislative level. Coastal areas, where industrial and port areas exist, are potential places of conflict between the many institutions that have jurisdiction (state and local authorities, port authorities).
The administrative and procedural complexity, the lack of clear and shared strategies, and a chronic lack of economic resources have led to the failure of almost all the proposals. ${ }^{8}$ Years of discussions, disputes, and hundreds of architectural and urban projects designed to regenerate the waterfront across Italy, have not, in most cases, produced the desired results (Savino, 2010) and, despite the few concrete achievements, the initiative has often been ceded to private investors, a dangerous trend that, in some cases, has produced problematic speculations (Pierotti, 2010). Many ambitions have not been realised (Pavia, 2012) and, although projects have begun to progress, thus far the only concrete and completed programmes are that of the Old Port of Genoa by Renzo Piano, (totally renovated to mark the occasion of the Columbus celebrations of 1992), while in Salerno the 'Sea Front' designed by the Catalan architect Ricardo Bofill is a project headlined by the construction of a monumental Crescent (Teodosio, 2014).

\section{Intervention Strategies on the Seafront}

The redevelopment of the land/water margin involves a set of tangible and intangible interventions, which are complex and varied. There is no single method and universally valid operational criteria for such projects, but as a result of completed schemes, it is possible to identify common strategies that characterise the regeneration of these areas.

The re-appropriation of these places cannot be separated from their accessibility. Therefore, it is essential to eliminate of all physical barriers between the city and the sea, through the demolition of the enclosing walls of the old ports; the removal or rerouting of railway lines and main roads and the construction of underground car parks). In addition, the upgrading of public transport and pedestrianisation make the recovered spaces generally more accessible and usable, providing locations for sport, leisure, and culture. In Barcelona, Moll de la Fusta (1983-1987), with its cross-section with steps, allowed the funnelling of traffic through an underground tunnel on top of which

\footnotetext{
${ }^{8}$ Examples of unrealised schemes include for the waterfronts of Naples, Palermo, Messina, and Reggio Calabria.
} 


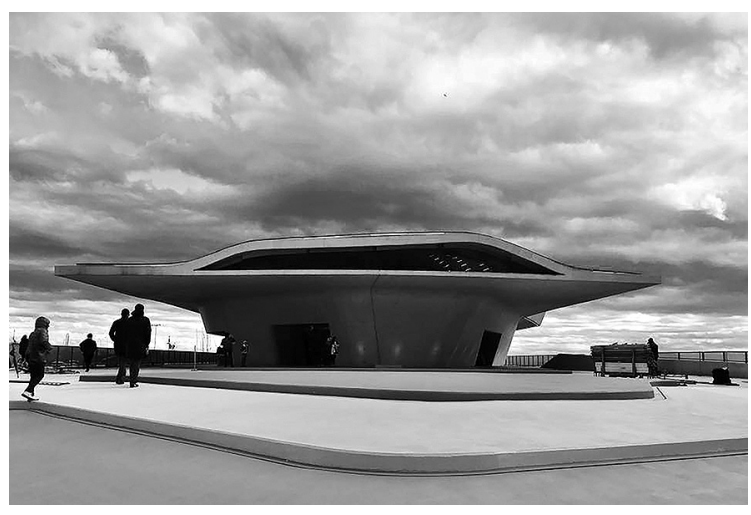

Figure 4 Salerno, Maritime Terminal designed by Zaha Hadid (Photo by Author)

pedestrian areas were created. The solution, designed by Solà Morales, solved the problem of crossing the road and contributes to the opening of the city to the sea. The relocation of the railway line from the Bilbao riverside freed the left bank of the estuary and established a large urban park. In Vigo, the burying of vehicular traffic in the Túnel de Beiramar, which runs under the boardwalk, allowed the reconfiguration of setting the coast.

Ports began to take on a new strategic role. Within old harbours, there were various port functions (leisure, traditional fishing boats and passenger), but these are compatible with urban use. These areas have taken on new functions thanks to the renovation of decommissioned port heritage; for instance, Genoa's Convention Centre is located in the former cotton warehouses, exhibition spaces have been created in Venice, and a hall for temporary exhibitions has been established in the former Trieste Fishmarket. The construction of new buildings also often assume a paradigmatic role. Salerno's maritime terminal, designed by architect Zaha Hadid and inaugurated in April of 2016, with its sinuous and daring forms, now dominates the old commercial port (Teodosio, 2017).

The role of representing the transformation and the new status acquired by a city often relies on the construction of a 'symbol building.' The case of the Guggenheim Museum in Bilbao is the most striking example in this category. There are other less wellknown cases, such as the Crescent in Salerno. Such buildings, often large and even bombastic statements, emerged on regenerated waterfronts and aspired to become, not necessarily always successfully, a new fulcrum around which the public space and social life of the city are organised. They stand as monuments of contemporary town planning, symbols of a renewed city's identity, a sign of renewal and rebirth. However, despite good intentions, many of these seem to seek only sensationalism and originality at all costs, by offering design solutions and an architectural vocabulary almost always out of context, which can be difficult to assimilate.

However, the redevelopment of the coast concerns not only sensational and futuristic architecture but often also includes a series of actions that, although less dramatic, are of fundamental importance. These include interventions needed to secure the natural character of the seafront, dictated by a growing sensitivity to environmental issues, including the nourishment of the beaches of Barcelona and land reclamation and the clean-up of the waters of the estuary in Bilbao to repair damage resulting from the former presence of steelworks.

\section{Conclusion}

In these various examples, a range of different approaches have been applied, and the regeneration programmes have varied according to the uses to which the regenerated areas will be put. The characters of the individual urban areas are very different, as well as the historical, geographical, political, social and economic conditions. Moreover, the success of some schemes does not imply that their 'model,' once exported, can guarantee the same results. Indeed, at times, it can generate bitter disappointments and disastrous failures. This happened at Barcelona, where the attempt to repeat the success of the operations related to the Olympics of 1992 generated the failed operation of the 2004 Forum of Cultures (Borja, 2004; 2010). This occurs whenever the regeneration of an area relies on the mere presence of a prominent building (Busquets, 2006).

The examples already undertaken can be useful models to inspire other architects and cities, who can draw lessons for future actions, provided that they do 
not 'copy' uncritically the model, but understand the essence and detect the underlying logic, its fundamental character, and the background processes.

Today there is a need for a co-ordinated overall. Therefore, any project for the regeneration of a waterfront must align itself with contemporary town planning thinking and propose approaches that promote the construction of new cultural attractions, while also attempting to find areas to allocate for residential and commercial functions. It favours a functional mixité, namely the peaceful coexistence of multiple functions. It is necessary to avoid the mass tourism, gentrification or the marginalisation of the area and to ensure that the regenerated coastal areas can be used and enjoyed at any time of year, at any time of day, by locals and tourists.

Waterfront regeneration and the recovery of abandoned port areas often change the face of the city, moving the physical centre of gravity of urban activities, creating a new equilibrium and improving the quality of life. The promenade becomes a public space par excellence, a meeting place for social gathering, and an attractive tourist destination. These interventions have a positive impact providing that they are based on an urban planning project of quality and they maintain a strategic balance between the necessary private profits of some activities (commercial, recreational, tourist) and the compelling visions of social development, along with the preservation of services, equipment and public spaces. The most successful projects, in fact, are those based on strategies that have been able to intelligently combine urban regeneration and economic development with respect for the natural and built environment and social needs.

\section{References}

Alemany, J. (2006). Gli obiettivi economici della rivitalizzazione dei waterfront. In Città-porto: Catalogo X Mostra Internazionale di Architettura, La Biennale di Venezia (pp. 61-63). Venezia, Italy: Marsilio Editore.

Balducci, V., \& Orioli, V. (2006). I temi architettonici del progetto degli spazi pubblici sull'acqua. Arredo \& Città, $19(2), 5-24$.

Borja, J. (2004). Barcelona y su urbanismo: Éxitos pasados, desafíos presentes, oportunidades futuras. In J. Borja \& Z. Muxí Martínez (Eds.), Urbanismo en el siglo 21: Bilbao,
Madrid, Valencia, Barcelona (pp. 171-182). Barcelona, Spain: UPC.

Borja, J. (2010). Luces y sombras del urbanismo de Barcelona. Barcelona, Spain: u oc.

Bruttomesso, R. (2007, March 7). Nuovi scenari urbani per le città d'acqua.' Lecture held at the Association Italia Nostra, Milan, Italy.

Busquets, J. (2006). Città-porto: Riconversione generica o specifica? In Città-porto: Catalogo X Mostra Internazionale di Architettura, La Biennale di Venezia (pp. 43-47). Venezia, Italy: Marsilio Editore.

Camporesi, P. (1992). Le belle contrade: nascita del paesaggio italiano. Milano, Italy: Garzanti.

Carta M. (2006). Waterfront Palermo: Un manifesto-progetto per la nuova città creativa. In Città-porto: Catalogo X Mostra Internazionale di Architettura, La Biennale di Venezia (pp. 227-231). Venezia, Italy: Marsilio Editore.

Cenicacelaya, J. (2004). Bilbao y la urgencia de un urbanismo sostenible. In J. Borja \& Z. Muxí Martínez (Eds.), Urbanismo en el siglo 21: Bilbao, Madrid, Valencia, Barcelona (pp. 22-38). Barcelona, Spain: U PC.

Copeiro de Villar, E. (1978). Los ritmos naturales de nuestras playa. Revista de Obras Públicas, 125(3157), 361-378.

Copeiro de Villar, E. (1980). Sobre la progressiva ruina de nuestras costas arenosas. Revista de Obras Públicas, 127(3179), 307-319.

Corbin, A. (1988). Le territoire du vide: L'Occident et le désir $d u$ rivage (1750-1840). Paris, France: Aubier.

Di Cristina, B. (2005). Brighton: Lungomare e forma urbana. In M. Massa (Ed.), Passeggiate lungo molti mari (pp. 279281). Florence, Italy: Maschietto.

Marciano, S. (2005). Sul waterfront delle aree portuali: Dalla Palazzata di Messina al progetto della via Marina a Napoli. Patrimoine de l'industrie: ressources, pratiques, cultures, 14(2), 27-31.

Marsala, M. T. (2002). Le città balneari dell'Ottocento. Palermo, Italy: L'Epos.

Martorell, J., Bohigas, O., Mackay, D., \& Puigdoménech, A. (1988). Transformación de un frente marítimo: Barcelona, La Villa Olímpica, 1992. Barcelona, Spain: G. Gili.

Massa, M. (2005). Fra mare e città: Le forme di uno spazio pubblico. In M. Massa (Ed.), Passeggiate lungo molti mari (pp. 13-29). Florence, Italy: Maschietto.

Massa, M., \& Zucchini, F. (2005a). La Promenade des Anglais a Nizza: Il modello mediterraneo. In M. Massa (Ed.), Passeggiate lungo molti mari (pp. 273-275). Florence, Italy: Maschietto.

Massa, M., \& Zucchini, F. (2005b). Il boardwalk di Atlantic City: La 'madre di tutte le passeggiate' d'America. In M. 
Massa (Ed.), Passeggiate lungo molti mari (pp. 291-294). Florence, Italy: Maschietto.

Nóvoa, M. (2005). Passeggiata marittima di Barcellona. In M. Massa (Ed.), Passeggiate lungo molti mari (pp. 211227). Florence, Italy: Maschietto.

Pavia, R. (2012). Nel mondo le aree waterfront sono le nuove centralità urbane del 21 secolo: Perché l'Italia invece si ferma? Il Giornale dell'Architettura, No. 103, 1.

Pié i Ninot, R. (2005). La gestione della costa in Spagna: Un'esperienza straordinaria. In M. Massa (Ed.), Passeggiate lungo molti mari (pp. 195-209). Florence, Italy: Maschietto.

Pierotti, P. (2010). Waterfront: Gare flop, sviluppo solo privato. Il sole 24 ore, No. $30,7$.

Pittini, S. (2006). Un paesaggio di oggetti: Il lungomare di Vigo in Galizia. Arredo \& Città, 19(2), 39-40.

Ronzani, G. (2006). La riqualificazione del waterfront urbano di Bilbao. Arredo \& Città, 19(2), 34-38.

Savino, M. (2010). Città e waterfront tra piani, progetti, politiche ed immancabili retoriche. In M. Savino (Ed.), Waterfront d'Italia: Piani, politiche e progetti (pp. 36-69). Milano, Italy: Franco Angeli.
Teodosio, A. (2014). Salerno 'città del turismo:' Ambizioni, progetti e realizzazioni per la città contemporanea. In $\mathrm{N}$. Fava \& M. Garcìa Vergara (Eds.), Territorios del turismo: El imaginario turístico y la construcción del paisaje contemporáneo (pp. 175-185). Barcelona, Spain: Viguera Editores.

Teodosio, A. (2017). La costruzione di una città turistica: I caso Salerno: Dall'apertura della via Marina alle recenti politiche di waterfront regeneration. Annali di Storia dell'Urbanistica e del Paesaggio dell'Università di Firenze, No. 3, 239-248.

Teodosio, A., \& del Caz Enjuto, M. R. (2013). Il recupero delle aree portuali dismesse come opportunità di crescita per la città contemporanea. In F. D. Moccia (Ed.), Città sobria (pp. 413-421). Napoli, Italy: Edizioni Scientifiche Italiane.

Trapero, J. J. (1988). El paseo maritimo, elemento clave de la ordenación del litoral. Urbanismo, No. 4, 30-39.

Vásquez Consuegra, G. (2008). Frente marítimo de Vigo. Barcelona, Spain: G. Gili.

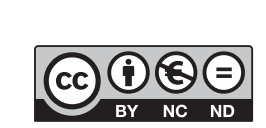

This paper is published under the terms of the Attribution- NonCommercial-NoDerivatives 4.0 International (CC B Y-NC-ND 4.0) License. 


\title{
Inventing Tourism in the Naval Port: The Case of the Brijuni Islands during the Habsburg Empire
}

\author{
Nataša Urošević \\ Juraj Dobrila University of Pula, Croatia \\ natasa.urosevic@unipu.hr
}

The present paper presents the results of the archival and field research conducted in the framework of the author's research project 'Valorisation of the common European heritage of Pula as the former main Austrian naval port and Brijuni Islands as an elite resort' in Austrian archives, with the focus on the Kupelwieser Collection kept in the Austrian National Library. The research aimed to offer a new perspective in the elaboration of the key initial phases of the development of modern tourism on the Brijuni Islands, by analysing their important function as an aristocratic residence near the main naval port in a comparative and transnational framework. The main research question was whether Brijuni followed a European model of development of an aristocratic resort near a major port. Combining archival and field research, the author has explored and compared some of the well-known island aristocratic residences in Europe and the Mediterranean, which developed as popular seaside resorts in the 19th and 2oth centuries, such as the Isle of Wight, Mallorca, Corfu, and Brijuni. An overview of the available recent theoretical literature provided comparative insights into the search for such a model of the successful symbiosis of resorts and ports. As a case study, the author analysed the development of tourism on the Brijuni Islands in the most dynamic and dramatic periods before, during, and after the First World War, bearing in mind their importance as an elite resort in close proximity to Pula as the former main Austrian (Austro-Hungarian) naval port.

Keywords: aristocratic residences, resorts, ports, Brijuni, Pula, tourism history https://doi.org/10.26493/2335-4194.12.31-40

\section{Introduction}

The European Year of Cultural Heritage and the commemoration of the end of World War I were an opportunity to reflect on the importance of Pula as the former main Austro-Hungarian naval port and the nearby Brijuni Islands as an elite aristocratic resort. Because of their strategically crucial geopolitical position, Pula and the Brijuni Islands had a particularly significant role in modern European cultural, political, diplomatic, and tourism history. After they had lost their key function and strategic role in the broader Central European and Mediterranean context, Pula and Brijuni stagnated, wanting for new development opportunities. The purpose of this paper is to present the results of the archival and field research conducted in Austrian archives in the framework of the author's research project 'Valorisation of the common European heritage of Pula as the former main Austrian naval port and Brijuni Islands as an elite resort,' with the focus on the Kupelwieser Collection, kept in the Austrian National Library. The research aimed to offer a new perspective in the elaboration of the key initial phase of the modern tourist development on the Brijuni Islands, by analysing their important function as 
an aristocratic residence near the main naval port in a comparative and transnational framework. The main research question was whether Brijuni followed a $\mathrm{Eu}-$ ropean model of development of an aristocratic resort near a major port. An overview of the available recent theoretical literature provided comparative insights into the search for such a model of the successful symbiosis of resorts and ports. As a case study, the author analysed the development of tourism on the Brijuni Islands in the most dynamic and dramatic period before, during and after the First World War, bearing in mind their importance as an elite resort in close proximity to Pula as the former main Austrian (Austro-Hungarian) naval port.

From the valuable archive material and rare collections kept in the archives in Vienna (Österreichische Nationalbibliothek [Austrian National Library] and Staatsarchiv [State Archiv]) and Graz (Landesarchiv [Provincial Archive] and Landesbiblitohek [Provincial Library]), it is possible to read an exciting story of an unknown part of the history of Brijuni. ${ }^{1}$ In addition to the 161 folders full of interesting rare photos and illustrations, letters, business plans and documents, the Kupelwieser Collection also contains unpublished parts of the autobiography of the owner of Brijuni, in which Paul Kupelwieser describes in detail the circumstances that led to his conflict with the Crown Prince Franz Ferdinand, who was so enchanted by the islands after his first visit that he wanted to take them over from the owner at any price and build a permanent residence there.

\section{Inventing Tourism in the Naval Port}

In 1850, Pula was selected as the site of the future most important Austrian military harbour, which gave the nearby Brijuni Islands a military function as well. Five fortifications were erected on Veli Brijun and two on Mali Brijun, and the Fažana Channel served as an an-

${ }^{1}$ This paper is result of the archival and field research, conducted in the framework of the author's research project 'Valorisation of the common European heritage of Pula as the former main Austrian naval port and Brijuni Islands as an elite resort' during the Richard Plaschka Fellowship of the Austrian Ministry of Research, Science and Economy. chorage for the Austrian fleet. In such circumstances, it was quite unusual that on August 15th 1893, the Viennese industrialist and steel magnate Paul Kupelwieser bought these uninhabited malaria-ridden islands at the entrance to the leading Austrian naval port of Pula. Twenty years later, on the eve of the World War I, the Brijuni Islands had been transformed into an elegant health resort, a world-renowned élite seaside destination, an exclusive meeting place for the European aristocracy, artists, and financial magnates, a symbol of cultivated relaxation, and a unique blend of nature and culture. The Brijuni Archipelago came to be known as a Mediterranean paradise at the foot of the Alps, a pearl of the Austrian Riviera, and an oasis of peace (Urošević, 2014).

Thanks to the frequent visits and extended stays of the Habsburg imperial family, close relations with the top industrial and military circles, and good maritime and railway connections with European capitals, shortly before the First World War, Brijuni developed into a focal point of social life on the Austrian Riviera, and an unique hub of technological and tourism innovations. As an Austrian counterpart to other prominent Mediterranean rivieras and resorts, Brijuni also had an extraordinarily important political, military and diplomatic function as an elite resort and cultural centre near the main naval port.

The period of intensive modernisation, industrialisation and urbanisation in southern Istria, which started after the opening of the Arsenal in Pula in $1856^{2}$ and which was accompanied at the turn of the century by the development of tourism in Pula and on the Brijuni Islands, was abruptly interrupted by the outbreak of the Great War, during which Brijuni again acquired strategic importance in defending the military harbour in Pula. The numerous forts on the islands were manned by crews, while the hotels served to accommodate Austrian officers. At the very peak of their development, after twenty years of intensive in-

${ }^{2}$ It is interesting to note that Karl Marx dedicated to Pula, the importance of its port, and its arsenal two articles published in the New-York Daily Tribune in January and August 1857. See http://marxengels.public-archive.net/en/MEo988en .html. 
vestments, their owner could have started returning huge invested capital, the islands were affected by the dramatic warfare.

Paul Kupelwieser described his life and entrepreneurial adventure in memoirs, published in $1918(\mathrm{Ku}-$ pelwieser, 1918). He was 76 when he died in Vienna in 1919, exhausted by severe illness and post-war uncertainty. The documentation and correspondence preserved in the collection of the rare manuscripts of the Austrian National Library testify to the dramatic circumstances in which his children took over the family business after the First World War, within a wholly transformed geopolitical framework. An unpublished part of Kupelwieser's biography, kept in the same collection, contains interesting details about his problematic relationship with the most famous guest of the Brijuni Islands, Crown Prince Franz Ferdinand, who was so enchanted by the islands after his first visit in July 1909 that he wished to build the permanent residence there. In the following three years, he spent several spring weeks on the islands where he completely cured his chronic lung problems. Paul Kupelwieser took advantage of his stay to launch a marketing campaign through the islands' newspapers - Brioni Insel Zeitung, published from 1910 to 1914. Delighted by the islands' climate, and natural and cultural heritage, the Crown Prince wanted to build a permanent residence there, which was a common habit among the European aristocracy. About his intention, he informed the German Kaiser, who visited Brijuni during his trip from Venice to his residence in $\mathrm{Corfu}^{3}$ in the spring of 1912. According to Kupelwieser, the Kaiser replied: 'Lucky you! You need only 12 hours to arrive at your paradise from Vienna, and I need 4 days to get to Corfu!' (Kupelwiser, 1917, p. 362). In addition to the climatic benefits, as well as the richness of natural and cultural heritage, it was the proximity to the empire's capital and its central position in the region, near the main naval port

\footnotetext{
${ }^{3}$ German Kaiser Wilhelm II purchased in 1907 the former residence of the Empress of Austria Elisabeth, Achilleion on Corfu, after her 1899 assassination by the Italian anarchist Luigi Lucheni in Geneva. During Kaiser Wilhelm's visits a great deal of diplomatic activity took place in Achilleion, and it became a hub of European diplomacy.
}

that made the future emperor's island residence so attractive.

It is evident that there are parallels and similarities in the habits and practices of the European aristocracy in creating residences in elite destinations, and that the Austrian court used the European models of best practice, both during the construction of naval ports and the development of elite tourist resorts in Central Europe and the Mediterranean. ${ }^{4}$

It is also known that Austria's ruling Habsburg family had a significant role in inventing and promoting the 'Austrian Riviera' (Baskar, 2010). Some of them were pioneers of tourism in the Mediterranean, such as the Archduke Ludwig Salvator, who 'discovered' and popularised many island destinations like Mallorca during his Mediterranean cruises (Woerl, 1899). Obviously, Mallorca could be a model for the development of an exclusive archipelago resort, as one of the first 'Mediterranean paradises,' which successfully attracted an elite aristocratic clientele and a cosmopolitan colony of artists and intellectuals (Walton, 2005).

\section{Resorts and Ports}

An overview of the available recent theoretical literature provides comparative insights in search of a European model of development of an aristocratic residence near the naval port. The monograph Resorts and Ports (Borsay \& Walton, 2011), discusses the relationship between tourist resorts and seaports in the history of tourism. In the introductory chapter, its editors also mentioned a kind of symbiosis of functions of the leading British naval port in Portsmouth and the aristocratic resort on the Isle of Wight, a favourite summer residence of Queen Victoria (Blom, 2008), emphasising that 'the Royal Navy offered a military spectacle to holidaymakers at Southsea or on the Isle of Wight' (Borsay \& Walton, 2011, p. 4). Other monographs, which emphasise the importance of comparative, transnational approaches in research on European resorts and ports (Zuelow, 2011; Borsay \& Furnée, 2015) are also very useful.

\footnotetext{
${ }^{4}$ About 'cultural transfers' between European spas see Borsay and Furnée (2015) and Steward (2000).
} 
The above-mentioned archival research conducted in the Austrian archives indicated that Pula was represented in the Austrian newspapers at the end of the 19th and early 2oth centuries as the 'Austrian Portsmouth' and that the Brioni (Brijuni) Islands were compared and described as 'even more beautiful than the Isle of Wight.' Rare collections in Austrian archives keep old local newspapers, such as Die Steierische Alpen-Post from 8 July 1905, in which, in the article Reisebriefe aus dem oesterreichischen Portsmouth by von Josef Steiner-Wischenbart Pula is compared with the main British naval port, as the 'Austrian Portsmouth' (Steiner-Wischenbart, n.d.). In contrast, in many articles published in the first tourism magazines on the Adriatic, such as the Oesterreichische Riviera Zeitung and Adria, as well as in Karl Brockhausen's (n.d.) study Brioni: Ein Kulturmärchen aus unseren Tagen, the Brijuni Islands were compared to the Isle of Wight. It is well-known that Austria, in the creation of its navy, used the best European practices, copying port infrastructure and fortification architecture models from the most developed European navies and employing top experts, such as the admiral of the fleet, the Dane Hans Birch von Dahlerup, who chose Pula for the main Austrian naval port in 1850 (Scandinavians dominated the corps of navy engineers throughout the 1850s), or the Pole Viktor von Domaszewski, the first urbanist of modern Pula, who, before the construction of the port infrastructure, visited all European (British, French, Dutch, and Russian) naval ports, including Portsmouth, Plymouth, London, Liverpool, Paris, and Toulon (Balota, 2005).

Looking for a model of an elite tourist destination development near the naval port, apart from archival and field research, it is undoubtedly a very useful comparative overview of the development of similar destinations in Europe. Combining the aforementioned methods, the author has explored and compared some of the well-known aristocratic island residences in Europe and the Mediterranean, which developed as popular seaside resorts in the 19th and 2oth centuries, such as the Isle of Wight, Mallorca, Corfu, and Brijuni.

Unlike Queen Victoria's summer residence in Osborne House, built in 1845 on the Isle of Wight, opposite the naval port in Portsmouth, in the style of the Italian Renaissance, Mallorca, Corfu, and Brijuni were typical Mediterranean aristocratic destinations, which developed as popular seaside resorts. Mallorca is the official holiday destination of the Spanish royal family, and the invention of modern tourism on the Balearic Islands is linked to visits of aristocratic guests and artists. After the first famous guests, Chopin and George Sand, who spent the winter of 1838/1939 in Valdemossa, in 1867 the Archduke Ludwig Salvator of Austria arrived. Having initially acquired properties in medieval Miramar, between 1872 and 1901, he purchased the entire coastal strip between Valdemossa and Deià, and built an extensive network of paths and viewpoints, creating a true paradise on Mallorca.

Besides learning the local dialect, Ludwig Salvator researched the islands' flora and fauna, history and culture, which resulted in the nine-volume monograph Die Balearen in Wort und Bild (The Balearic Islands in Word and Image). For many decades, the Archduke explored the Mediterranean with his famous yacht 'Nixe.' He preferred small and undiscovered regions and islands, such as Paxos and Antipaxos, Ithaka, Levkas and Zante in the Ionian sea as well as the Liparian Islands north of Sicily, the small islands Giglio, Ustica, and Alboran and especially the Balearic Islands Mallorca, Menorca, Ibiza, and Formentera (Woerl, 1899). A special congeniality of spirit connected the royal vagabond with Empress Elisabeth ('Sisi'), who held the educated archduke in high esteem. She visited him twice with her yacht 'Miramar' on Mallorca (see http://www.ludwigsalvator.com).

The landscape of the Serra de Tramuntana, protected in 2001 by UnESCO, holds the famous trail built by Ludwig Salvator, as well as a literary trail from Valldemossa to Pollença, which pays homage to George Sand and Robert Graves and the highly scenic Sóller to Palma narrow-gauge historic railway.

The Austrian empress, Elisabeth of Bavaria, built another very famous aristocratic residence on the Island of Corfu, after the tragic loss of her only son, Crown Prince Rudolf of Austria, in 1889. The Achilleion Palace, inspired by Greek mythology, was Elisabeth's favourite vacation place and summer residence, dedicated to her admiration for Greece, its language and its culture until her tragic death in 1899. After 
Elisabeth's assassination, German Kaiser Wilhelm II purchased Achilleion in 1907 and used it as a summer residence. Until 1914, many diplomatic activities took place in the palace, and Achilleion became a hub of European diplomacy. During World War I, Achilleion was used as a military hospital by French and Serbian troops (see https://www.habsburger.net/en/chapter /achilleion-corfu-elisabeths-flight-antiquity). Briefly reclaiming the status of the centre for European diplomacy that it possessed during the Kaiser years, the Achilleion has been used in recent times for European summits and as a museum.

\section{Years of Fulfillment}

Aristocratic visits marked probably the most exciting period of development and international recognition of Brijuni, from Easter 1910 to the beginning of the First World War, and can be traced through the preserved editions of the Brijuni Islands newspapers. In addition to the first tourist magazines in the Adriatic: the Illustrierte österreichische Riviera Zeitung (1904-1905) and Adria, Illustrierte Monatsschrift für Landes- und Volkskunde, Volkswirtschaft und Touristik der adriatischen Küstenländer (1908-1914), the Brijuni Islands had their own newspaper: Brioni Insel Zeitung (1910-1914). The first issue of the islands' gazette, which was published in March 1910, reported on the stay of Franz Ferdinand with his family on the Brijuni Islands, and it is evident that the presence of the imperial family was used to promote the destination (which was a frequent practice in other European destinations visited by aristocracy). The newspaper regularly reported, among other things, about the stay of the emperor's family, as well as other famous personalities, which can be traced through the list of guests published in each issue (see http://library.foi.hr/ novine).

Another valuable source is the tourist magazine Adria, which reports about Franz Ferdinand's visits to Brioni in several issues in 1910. After his first working visit in July 1909, during the Adriatic tour from Venice to Corfu on the imperial yacht 'Miramar' (Adria, August 1909, p. 341), in the issue from February 1910, Adria reported about the first longer stay (February and March) of the Archduke's family on the Adriatic coast, with a six-page report on the islands' beauty (Adria, February 1910, pp. 77-88). The issue from April 1910 reported about A Year of Fulfilment (Adria, April 1919, pp. 157-160) with an illustrated reportage and the photo of the archduke with his wife on Brijuni. Finally, the issue from June 1910 reported about his activities during a two-month stay. Apart from treating lung problems and enjoying the beauty of nature and peace, the crown prince was very interested in studying the preservation of cultural monuments and learning about the cultural and economic development of the Austrian Riviera as well as in the nearby naval port. Almost every day he visited, by car or by boat, the Istrian coast and the interior, from the surroundings of Pula to Učka, including the opening of the Provincial Exhibition in Koper. In conclusion, the editors reported that he was so satisfied with his stay on Brijuni that he announced his intention to choose beautiful Istria as a permanent residence for the first weeks of spring (Adria, June 1910, pp. 237-240). The issue of March 1911 briefly reports on his arrival to Brijuni with the whole family for another two-month stay.

Another very valuable and useful source are memoirs of the Brijuni's owner Paul Kupelwiser, Aus den Erinnerungen eines alten Österreichers (From the Memoirs of an old Austrian), written in 1917 and published in 1918 (Kupelwieser, 1918). It is fascinating to observe that Kupelwieser's memoirs end with the first visit of the crown prince, his imperial highness Franz Ferdinand and his wife, the Duchess of Hohenberg. However, the original manuscript (actually a typoscript), kept in four folders of the Kupelwieser Collection in the Austrian National Library (Kupelwieser, 1917), also include, an unpublished part, with much less wellknown details related to the owner's efforts to struggle with nature, the state bureaucracy, and the military authorities. Particularly interesting and impressive are pages describing Franz Ferdinand's attempts to take over the islands and build a permanent residence on them. The typoscript in the third and fourth folder contains a detailed description of the preparations for the first longer stay of the Crown Prince's family on the islands in 1910. At the beginning of February 1910, the heir to the throne arrived with his family on the 
islands. They enjoyed very much the pleasant island climate during their eight-week stay, so that Franz Ferdinand felt his chronic lung problems no more, which was not the case after his stays on the French Riviera and in St. Moritz.

From the letter of the head of the cabinet (Vorstand der Militär Kanzlei) Alexander von Brosch-Aerenau to Franz Ferdinand from March 16, 1910 (BroschAerenau, 1910), it is also possible to read about the archduke's intentions to build a residential villa on the western Istrian cost, more precisely on the Brijuni Islands. He was authorised to negotiate the acquisition of Peninsula Barbana at the north-western tip of the island or Cape Peneda in the very south, for which the Archduke was particularly interested. According to the negotiator, Kupelwieser was more willing to give up Cape Peneda than Barbana, because he needed the field for his livestock and local traffic, but also because of the planned construction of the bridge from Barbana to Brioni Minor. Kupelwieser did not want to sell anything but proposed a lifelong or longer lease. He was ready to renounce any payment, demanding that after the lease had ended, everything would pass back into his (or his heirs') possession. Although BroschAerenau did not consider Kupelwieser's offer acceptable, after detailed calculations, he recommended further negotiations.

In his (unpublished) memoirs, Paul Kupelwieser describes the visit of the head of the cabinet, Colonel Brosch, who attempted to negotiate on behalf of Franz Ferdinand. He informed Kupelwieser that his Imperial Highness was 49 years old and, as the future emperor, needed a residence, and it was to be Brijuni. During Easter 1910, the Brijuni islands were visited by the court garden director Umlauf, who was asked to have a closer look at the islands and to estimate the value of the whole estate. He estimated that because of the islands' climatic benefits with the same isotherms as Lošinj and the wealth of abundant fertile soil as well as relative proximity of Vienna, Brijuni were worth 25,000,000 crowns and that his Imperial Highness could pay even $30,000,000$ crowns. According to Kupelwieser, these amounts, which were well over twice what he had invested in Brioni, were probably the reason that Franz Ferdinand no longer thought of the purchase, but sought other ways in which the desired goal could be achieved. Several weeks after this estimation, an article was published in the Paris issue of The New-York Herald, announcing that the political situation in Italy made it urgently necessary that the state acquire the Brijuni islands. Parts of the islands that were not used for fortification purposes could be left to the heir to the throne as a stay there had proved to be very favourable to his health (Kupelwieser, 1917, p. 357). Kupelwieser denied this false report in his own newspaper (Brioni Insel Zeitung, 29 march 1910).

From the unpublished part of the Kupelwieser memoirs, it is evident how much he was concerned with the intense pressures related to the Archduke's wishes to take over the island, which affected his nervous system so much that he had heart problems several weeks after his departure. Apart from heart spasms, throughout the whole spring, summer, and autumn of 1910, Kupelwieser had problems with boils on various parts of his body and with eczema which could not be effectively treated. In autumn, he decided to visit dermatologist Prof. Dr Una in Hamburg, and since the disease caused by stress became complicated, he had to lie in bed because of painful boils and eczema (Kupelwieser, 1917, p. 321). Kupelwieser used his stay in Hamburg to visit Karl Hagenbeck in his famous zoo and arrange his visit to Brijuni the following year (in January 1911).

In the meantime, the harbour admiral, Excellency von Ripper, also attempted to complicate or block every investment in the islands in the next three years. Although the construction of the new hotel Neptun III, designed by the young architect Eduard Kramer, was repeatedly interrupted, until the next Easter season in 1912 and re-arrival of prominent guests, the hotel was completed, which also enabled a larger visit of the most distinguished Viennese circles. It was the year of fulfilment and the highest ranking visits, according to local tourist magazines. At the invitation of Franz Ferdinand, on his trip from Venice to Corfu, the German Kaiser visited the islands. Along with the solemn welcome of the war fleet, the emperor was welcomed by 400 guests of the Brijuni spa. The presence of such high-level guests on Brijuni greatly contributed to the 
island's promotion, so much so that all rooms were sold out several weeks before the Kaiser's arrival (Kupelwieser, 1917, p. 362).

Finally, Kupelwieser offered the construction of the residence, the castle with a larger park surrounding the villa on the Peneda peninsula, which was one fifth of the island's surface. Kupelwieser offered Franz Ferdinand a twenty-year lease, so he could use it under the same conditions as long as he lived (Kupelwieser, 1917, p. 363). After unsuccessful negotiations, Franz Ferdinand seemed to give up taking over the Island, and over the next two years he spent the late winter at the Miramar Castle near Trieste. The intention of Franz Ferdinand to take over Brijuni is also confirmed by the book of his secretary in which, in the chapter entitled Brioni, he describes in detail the relation of the crown prince towards Kupelwieser and his attempts to become the owner of the most attractive parts of the islands, in the broader context of political and diplomatic relations and visits (Nikitsch-Boulles, 1925, pp. 140-150).

\section{Ambitious Development Plans}

In the winter before the outbreak of World War I, massive investments were completed: the visitors of Brijuni's five deluxe hotels with 500 beds could enjoy the first indoor swimming pool with heated sea water in Europe in a wellness centre, which was opened in October 1913. In the unpublished part of his memoirs, Paul Kupelwieser mentions Dr Neumann's proposal for the construction of a sanatorium projected by the architect Kramer a few months earlier in the framework of his ambitious plans to develop a health tourism resort. Several weeks after that, Franz Ferdinand was killed in Sarajevo. Because the First World War began four weeks later, Kupelwieser commented that he was glad that the construction for which he had been ready had not begun (Kupelwieser, 1917, pp. 373-374):

I'm thinking about the future enlargement of our hotel resort through the arrangement of about 100 rooms in the hotel on the west coast of Brijuni, perhaps at the same place where a sanatorium was planned, not as a private joint stock company, but in the joint venture with our own hotel company and led by well-paid medical staff.

The most informative preview of the most prosperous period before the First World War, and probably the most comprehensive guidebook is the Führer durch Brioni (Gnirs, 1910).

Along with the already published autobiographical notes of the island's medical doctor Otto Lenz's wife Brijuni - Lost Paradise, (Lenz Guttenberg, 2007), which include important details related to the events on the island on the eve of the First World War (such as the arrival of the British fleet just before the very beginning of the war), in some very informative Brijuni guide books from the 1920 s and '30s, written by the islands' physician Otto Lenz, there are interesting details about the First World War. In the publication Die Bedeutung der Insel Brienz als hervorragender Climatischer Kurort der Nordadria, we can read that 'the war passed almost unperceived near Brijuni [...] only a few bombs would fall on Brijuni, but without any damage [...] That is how our beautiful island could, after the peace agreement, be awakened again from the unwanted four-year-old dream' (Lenz, 1930, p. 4). We can also learn that immediately before the outbreak of the war, large investments were completed: with a unique indoor heated swimming pool connected to the rooms with a heated corridor, Brijuni had 300 rooms in five hotels that could accommodate 450 guests. The heated swimming pool should be the centre of future development of Brijuni as a winter spa, insisted Dr Lenz in conclusion of his very informative guide. He also announced intensive equipment of the spa centre, the building of a new sanatorium, in addition to the existing hotels, where guests will be offered special treatments, massages and hydrotherapy, mud therapy, diets, and seawater inhalation, 'as in Salsomaggiore spa.' The future spa and wellness centre would include a gym room and fitness in the pool, along with the unavoidable walks over $8 \mathrm{o} \mathrm{km}$ of decorated paths. In conclusion, the indications for treatment were listed.

Particularly impressive is a booklet Spaziergänge auf Brioni (Lenz, 1926) in which the island's physi- 
cian, through a proposal of 12 walks through the picturesque Brijuni Islands, also recounts the history of Brijuni as a tourist destination, presenting a whole range of important details.

Dr Lenz, among other things, elaborated a significant project to build a sanatorium in Madona Bay, which was planned before the start of the First World War (also mentioned by the publicist Richard Voss (1914) in his book Die grüne Insel, dedicated to the owner of Brijuni. Because of the best climatic conditions in the Madona Bay, after a long period of reflection on arranging the winter sanatorium for convalescence, a joint stock company was organised. The plans were completed, the construction was approved by the Austrian command of the naval port (with the condition that the building be coloured green so as not to become the target of the enemy), the capital for construction was also ready; then the war came and blocked the project.

This information is confirmed by an unpublished development study from 1919, which is also kept in the Kupelwieser Collection. After the war and in the year of Paul Kupelwieser's death, his heirs founded the Brioni joint stock company in 1919. The contract, held in the Department for the Rare Collections of the Austrian National Library, is one of the few documents related to the company's business (Kupelwieser, 1919). This document, which presents a feasibility study and a strategic framework for further development of the islands at the same time, apart from financial structure, which includes both future British and us investors, mentions detailed ambitious development plans, including, for example, connecting the Veli Brijun to Mali Brijun (Brioni Minor) by a bridge, and further spreading of the health resort offer through a new sanatorium in Madona May, as well as new spa complexes on both islands. Another document related to this substantial investment, which was unfortunately interrupted by World War I, is an architectural project for a never-built health resort in the Madonna Bay, a work of the well-known architect, Eduard Kramer (who designed almost all the hotels in Brijuni) dating back to 1915 .

Along with another unrealised project, a large 1905 seafront hotel, there is also a project for a large Kurhaus building that was to be built in Dobrika Bay. The spa building was supposed to be five stories high in the central part and only one floor in the wings. About 120 accommodation units were planned in this impressive health resort.

After the war, when, after great political changes, Istria and Brijuni fell under the authorities of Italy, only huge debts remained. Paul Kupelweieser died shortly after the collapse of the monarchy in 1919. His son Karl continued his venture with less success, and new investments in golf and polo fields only increased the enormous debts. After additional family problems, he took his own life in 1930, and in 1936 Brijuni was sold to the Italian state.

Very interesting is also the preserved documentation from the family legacy (diaries, letters and reports) after World War II, which testifies about the first visit of Kupelwieser's family members to the Islands after the forced departure in 1935. The letter from October 1960, written by family members (Mautner Markhof, 1960) who were pleasantly surprised by the reception by the new authorities, documents their reasons for leaving the islands in 1935, as well as the current situation in Brijuni, which in the meantime had become a presidential residence.

\section{Conclusion}

At the end of the Second World War, on 5th May 1945, the Brioni Islands were liberated with the rest of southern Istria, and were under the control of the Yugoslav Government, in contrast to Pula, which was then under Allied control. Josip Broz Tito, the president of the Federative Peoples' Republic of Yugoslavia, came to Brioni on 2oth June 1947 and declared them a residential area (Begović \& Schrunk, 2007, pp. 155-166). Since that time, extensive work had begun on their recovery from the damage inflicted by bombing. From 1952 to 1981 , numerous foreign dignitaries visited Brijuni, including members of European royal families and high-ranking diplomats. The summer presidential residence was built on the Island of Vanga. The Brijuni Islands were an important venue of historical meetings of the 20 th century. In October 1983, the Brijuni Islands were declared a National Park.

In their turbulent history, from the Roman era to 
the modern times, the Brijuni Islands had a significant economic function, related to elite leisure, but also a prominent political and diplomatic role, as a residence. The conducted research has indicated similarities, common practices and models of the elite European spas and seaside resorts, including the relation between resorts and ports, which could also be useful in the analysis of tourism development on the Brijuni Islands.

Valuable rare archival documents kept in Austrian archives, related to the development of tourism on the Brijuni Islands in the most dynamic and dramatic period before, during and after the World War I, can illuminate previously unknown sections of the past of the Brijuni Islands and should, therefore, be further analysed and presented. Since the archival material related to the history of Brijuni is dispersed in different institutions and partially lost, it is essential to continue research, which could reconstruct some critical events. Besides the afore-mentioned Austrian archives and collections, there are fascinating sources in archives in Trieste, Pazin, and Belgrade, which should be analysed in greater detail. The European Year of Cultural Heritage, besides commemorating the end of the First World War and celebrating the common European values and heritage, was an opportunity to valorise former aristocratic residences as common Euro-Mediterranean heritage through transnational projects and networks as well as international labels (European heritage label, UnEsco heritage, etc.).

\section{References}

Balota, M. (2005). Puna je Pula. Pula, Croatia: Amforapress. Baskar, B. (2010). Southbound, to the Austrian riviera: The Habsburg patronage of tourism in the Eastern Adriatic. Anthropological Notebooks, 16(1), 9-22.

Begović, V., \& Schrunk, I. (2007). The Brioni Islands: Past, architecture and cultural heritage. Zagreb, Croatia: Golden marketing-Tehnička knjiga.

Blom, P. (2008). The vertigo years: Change and culture in the West, 1900-1914. New York, NY: Basic Books.

Borsay, P., \& Furnée, J. H. (Eds.) (2015). Leisure cultures in urban Europe, c. 1700-1870: A transnational perspective. Manchester, England: Manchester University Press.

Borsay, P., \& Walton, J. K. (Eds.) (2011). Resorts and ports: Eu- ropean seaside towns since 1700. Bristol, England: Channel View Publications.

Brockhausen, K. (N.d.) Brioni: Ein Kulturmärchen aus unseren Tagen. Sammlung Kupelwieser (Cod. Ser. n. 53114), Österreichische Nationalbibliothek, Vienna, Austria.

Gnirs, A. (1910). Führer durch Brioni. Vienna, Austria: Kunstdruckerei Frish.

Kupelwieser, P. (1917). Aus den Erinnerungen eines alten Österreichers [Manuscript]. Sammlung Kupelwieser (Cod. Ser. n. 53025/1-4), Österreichische Nationalbibliothek, Vienna, Austria.

Kupelwieser, P. (1918). Aus den Erinnerungen eines altes Österreichers. Vienna, Austria: Gerold.

Kupelwieser, L. (1919). Die Aktiengesellschaft Brioni: Im Auftrag des Familienverwaltungsratses. Sammlung Kupelwieser (Cod. Ser. n. 53034), Österreichische Nationalbibliothek, Vienna, Austria.

Lenz, O. (1926). Spaziergänge auf Brioni. Vienna, Austria: Trupp.

Lenz, O. (1930). Die Bedeutung der Insel Brioni als hervorragender Climatischer Kurort der Nordadria. Vienna, Austria: Trupp.

Mautner Markhof, M. (1960, 17 October). Nach 25 Jahren Wiedersehen mit Brioni. Sammlung Kupelwieser (Cod. Ser. n. 53050), Österreichische Nationalbibliothek, Vienna, Austria.

Nikitsch-Boulles, P. (1925). Vor dem Sturm. Erinnerungen an Erzherzog Thronfolger Franz Ferdinand. Berlin, Germany: Verlag fuer Kulturpolitik.

Steiner-Wischenbarth, J. (N.d.). Nachlass, Sein Leben un Wirken (K.3, H.13). Landesarchiv Graz, Graz, Austria.

Steward, J. (2000). The spa towns of the Austro-Hungarian empire and the growth of tourist culture: 1860-1914. In P. Borsay, G. Hirschfelder, \& R.-E. Mohrmann (Eds.), New directions in urban history: Aspects of European art, health, tourism and leisure since the enlightenment (pp. 117-120). Münster, Germany: Waxmann Verlag.

Urošević, N. (2014). The Brijuni Islands - Recreating paradise: Media representations of an elite Mediterranean resort in the first tourist magazines. Journal of Tourism History, 6(2-3), 122-139.

Von Brosch-Aerenau, A. (1910, 16 March). [Letter to Franz Ferdinand]. Sammlung Kupelwieser (Cod. Ser. n. 53172), Österreichische Nationalbibliothek, Vienna, Austria.

Voss, R. (1914). Die grüne Insel: Ein homerisches Eiland in der Adria; Aus meinem Reisebuch. Vienna, Austria: Helios.

Walton, J. K. (Ed.). (2005). Histories of tourism, representation, identity and conflict. Clevedon, England; Buffalo, Ny; Toronto, Canada: Channel View Publications. 
Woerl, L. (1899). Erzherzog Ludwig Salvator aus den österreichischen Kaiserhause als Forscher des Mittelmeeres. Leipzig, Germany.

Zuelow, G. E. (Ed.). (2011). Touring beyond the nation: A transnational approach to European tourism history. Farnham, England: Ashgate Publishing. 


\title{
Tourism on the Croatian Adriatic Coast and World War I
}

\author{
Jasenka Kranjčević \\ Institute for Tourism, Croatia \\ jasenka.kranjcevic@iztzg.hr
}

Research on tourism history has been mainly confined to considering tourism area life cycles (TALC). Although destinations with a tourism tradition spanning over a century have undergone various life cycles, their tourism history has rarely been considered in the context of global changes, such as World War I, and how and to what extent these global changes have affected the development of tourism in the tourist area and tourism architecture. Since no direct hostilities took place in the area of present-day Croatia during WWI, the present paper investigates the indirect impact of the war as a global event on the rise of tourism at the time through unbuilt tourism architecture, which may be seen as halting investments in tourism. This research may be used to consider the creation of a model for global tourism life cycle by stages, including also paradigmatic changes in the design of tourism architecture.

Keywords: World War I, global tourism cycle, tourism area life cycle, unbuilt tourism architecture, Croatia

https://doi.org/10.26493/2335-4194.12.41-53

\section{Introduction}

Regardless of the potential possessed by a specific destination for tourism development (climate, natural and cultural heritage, human resources, etc.), an often-neglected fact is that its tourism area life cycle (TALC) depends directly or indirectly on global events, in particular, world wars. In this respect, there is a lack of global interdisciplinary research on the impact of global wars on tourism development, as well as on the paradigm shift on tourism and tourism architecture.

Only complex interdisciplinary research can yield an answer to the question of what the Great War (1914-1918) changed directly and indirectly in tourism. Given that global (WWI and WWII) and regional wars (Vietnam, Palestine, Homeland War in Croatia, etc.) strongly impact all tourism activities (Butler \& Suntikul, 2013), there is a lack of research on the impact of war on tourism development through halting investments, that is on building tourism architecture, especially during the war.
Safety is an essential prerequisite for the development of tourism and the choice of the destination while lack of safety damages the image and competitiveness of a destination (Richard, 2003; Frey, 2004; Mansfeld \& Pizam, 2006). War, the proximity of war, or terrorist events strongly influence tourism, primarily reflected through a sudden decline in tourism figures (Dragičević, Nikšić Radić, \& Grbić, 2018). There is a lack of research in Croatia on the impact of global historical events, such as WWI, on the development of tourism on the Croatian coast at the time through the stagnation of investments in tourism, i.e., through unbuilt tourism architecture.

The subject of this research is, therefore, the recognition of increased tourism on the Croatian Adriatic coast before WwI and a sudden drop in tourism figures due to the onset of war operations in Europe, resulting in the stagnation of investments in tourism. That stagnation can be traced through unbuilt tourism architecture. The phrase unbuilt tourism architecture, 
due to the outbreak of wWI, indicates architecture projects in the field of tourism (hotels, nautical centres, sports centres): ${ }^{1}$

- that had been designed and/or prepared for construction,

- for which public architecture competitions had been conducted just before the outbreak of the war,

- that were prepared by public institutions (e.g., Ministry of Public Works),

- that were discussed during the war,

- that were discussed after the war because they had not been built.

This means that these architecture projects were at a relatively high level of preparation for construction and can be characterised as investments in tourism that had been halted. Investments in tourism require years of preparation and several years for construction (market analysis, sorting out property ownership issues, project development, finding the workforce, securing building material, etc.).

The aim of collecting and making an inventory of unbuilt tourism architecture on the Croatian Adriatic coast is to link the impact of global events, in this case, WWI, with the development of tourism and the design of tourism architecture, and the reflection on a global understanding of life cycle tourism.

Apart from tourism architecture, ww I halted the construction of new railway lines from Zagreb to Dalmatia and a railway line from Slavonia via Bosnia and Herzegovina to Dalmatia, but they are not the subject of this paper.

\section{Literature Review}

In scientific literature, experts agree that war, terrorism, and different types of crises strongly affect tourism revenue and thus also investments in tourism (Čorak, Mikačić, \& Ateljević, 2013).

In the recent literature on tourism, war has often been considered for creating social memory (Lisle, 2000; Winter, 2009), which includes the selection and articulation of information on the war because

\footnotetext{
${ }^{1} \mathrm{~A}$ large number of Croatian men took part in wWI.
}

it establishes a connection between the past and the present. Regarding wwI, between 2014-2018, many countries of south-eastern Europe (Bosnia and Herzegovina, Austria, Hungary, Croatia, Slovenia etc.) organised scientific meetings to mark a century since the beginning or the end of wwi. Presented at these meetings were most frequently the political, historical, military and medical aspects of the war. Studies related to the linkage between tourism and w w I mainly concerned the recognition of events from World War I and their transformation into a tourist attraction (Kavrečič, 2016) and how to use it for education (George \& Das, 2017).

Regarding research on tourism history from the interdisciplinary aspect, it is somewhat marginalised in the literature, although this has slowly started to change (Walton, 2009) given that the historical aspect is increasingly represented at numerous scientific conferences on tourism (Baranowski \& Furlough, 2001; Berghoff, Korte, Schneider, \& Harvie, 2002; Koshar, 2002; Tissot, 2003; Walton, 2005).

In the world literature, very few papers focus on researching the impact of global political and war events on global tourism development (Gillena \& Mostafanezhadb, 2019), especially during the very beginnings of the development of modern and global tourism. In Croatia, too, little attention has been paid to interdisciplinary research on tourism history, although a significant number of places boast a tourism tradition more than a century-long (Blažević, 1987; Vukonić, 2005; Vasko-Juhász, 2006). In the context of tourism history, research on tourism architecture is particularly neglected, although it plays a vital role in the range of tourism services. Interestingly, certain destinations, as well as corporations, create their identity with the help of tourism architecture from the beginning of the 2oth century (Vasko-Juhász, 2006). The history of tourism architecture is mainly the subject of research of art historians or architects (FlückingerSeiler, 2003; Keck, 2008) and is rarely associated with trends in tourism and how tourism architecture depends on global influences (Kranjčević, 2018b).

To link tourism and architecture at the beginning of the 2oth century (i.e., until the outbreak of wwI), this research mostly used literature (books and maga- 
zines) in German and Croatian and available archival material from archives and museums.

Maximilian Krauss wrote on several occasions about the negative impact of WwI on tourism in Germany (Krauss, 1915, 1918, 1923) and linked it with international and domestic tourism figures, as well as with the negative impact on the economy. For understanding tourism circumstances in the Austro-Hungarian Empire, as well as on the Croatian Adriatic coast before WWI, valuable sources include tourism journals Österreichische Touristen-Zeitung (1881-1938) [Journal of Austrian Tourism], Fremdenverkehr (1908-1914) [Tourism] and Moderne Illustrierte Zeitung für Sport und Reise [Modern Illustrated newspaper for Sports and Travel], published in Vienna, as well as tourism journals published in Croatia, specifically in Opatija (Kur- und Bade-Zeitung der österreichischen Riviera, 1906-1914) and on the Brijuni Islands (Brioni Insel Zeitung). Tourism planning before w w I was the matter of advisors the imperial court, but also of their public actions (Schindler, 1912).

To understand tourism architecture on the Croatian Adriatic at the time, articles from journals such as Der Architekt [Architect] and Wiener Bau-Industriezeitung [a Viennese construction industry newspaper] were used while monographs of individual architects were used to investigate hotel projects unbuilt because of the outbreak of wWI (Boyd Whyte, 1989; Kranjčević, 2013). During the war, architecture journals attempted to affirm and justify some of the tourism architecture projects such as, for example, by architect Alfred Keller on the Croatian coast (Dalmatia), recommending that it be finished it as soon as peace is restored (V. F., 1916, 1918).

Prior to the cancellation of the Fremdenverkehr [Tourism], Moriz Band (1914), as a significant authority on tourism opportunities on the Croatian Adriatic, thought in 1914 that the war would soon end. A year later, R. E. Petermann (1915) published in the Österreichische Touristen-Zeitung [Journal of Austrian Tourism] a detailed article about the negative impact of war on nature, the landscape, tourism and tourist arrivals. $^{2}$

${ }^{2}$ R. E. Petermann is the author of the famous and extensive
From the literature on Croatian tourism history (general overview) in the Croatian language, a book by Boris Vukonić (2005) was used. Apart from research at the state level, valuable research on the history of tourism also exists at the regional level. The works useful for the understanding of tourism history at the regional or local level were by Lavoslav Golf (1929) for Dalmatia and Ivan Blažević (1987) for Istria and Kvarner. There is also valuable research on tourism history of local destinations such as Dubrovnik (Perić, 1983), Zadar (Jadrešić \& Jurić, 1985), Baška (Šale \& Pavlović, 2004), Opatija (Zakošek, 2005), Makarska (Urlić, 2008), Hvar (Petrić, 2018) among others. Their research does not analyse the impact of WWI and wWII but helps to understand how wars represent a turning point in tourism. Ivan Pederin (1991) analysed Austrian and German travelogues and their influence on the promotion of the Croatian coast.

However, there are no works that link the impact of global events on tourism architecture and the interruption of investments in it. Therefore, this paper aims at linking the impact of global wars on trends in tourism and on tourism architecture. Although research into contemporary tourism seeks to link trends in tourism with the use of tourism architecture, there has been no research into the impact of the war on architecture. Similarly, little research has been done on tourism promotion that promoted tourism architecture, in addition to natural and cultural heritage prior to WWI (Pederin, 1991; Storch, 2013; Kranjčević, 2018a).

\section{Research Design and Methods}

To explore the fascinating impact of the global war on tourism, the present paper relies on the research of unbuilt tourism architecture in 13 tourist destinations on the Croatian Adriatic. Although there were no direct hostilities on the territory of present-day Croatia, the war had a strong indirect impact on tourism development. For this reason, the analysis of the impact of the war on tourism development was embedded on the example of the Croatian Adriatic coast as a theoreti-

guide on Dalmatia Führer durch Dalmatia [Guide through Dalmatia] (1899). 
cal confirming study case based on the so-called most likely or typical case.

To investigate the impact of WWI as a global event on the TALC of the Croatian Adriatic, the paper relies on the creation of an inventory of planned architecture projects for tourism purposes that had not been built because of the outbreak of the war.

The paper first briefly describes the conditions for tourism and the rapid growth of tourism figures from the end of the 19th century until the beginning of the war, that is until the beginning of a sudden decline in tourism figures, in order to point out the negative impact of WWI on tourism development. Numerous investment projects were halted due to the decline in the number of tourists, the insecurity of investment, and the insecurity of passenger traffic on the Adriatic.

Notwithstanding the fact that the paper focuses on unbuilt tourism architecture, it should be noted in the introductory part that the inventory of tourism figures relies on available statistical data on settlements on the Croatian Adriatic coast, especially those after wW I.

This research on the impact of WWI on the development of tourism on the Croatian Adriatic coast faced certain limitations because that planned investments in tourism had not been listed in a table or itemised in any other way; therefore, the research relied on collecting information from journals (of tourism and architecture), biographies of architects, and materials preserved in archives and museums (Croatia, Czech Republic).

Prior to WWI, the Croatian coast had been governed from Vienna, the capital of the Austro-Hungarian Empire, whereas after WWI its territory was divided between the Kingdom of Italy and the Kingdom of Serbs, Croats and Slovenes.

Based on investments halted in different destinations on the Croatian Adriatic, the paper attempts to link TALC with global events. By observing the consequences of global events on investments in tourism on the Croatian Adriatic and on architectural design, the paper attempts to test one of the most commonly used models for the analysis of TALC (Butler, 1980). Since no quantitative data exist, the research is based on the conclusion drawn from quantitative research. The Croatian Adriatic coast, attractive and rich in natural and cultural heritage, recorded soaring figures in tourist arrivals up to wWI. The area underwent significant transformations, with types of buildings unknown before that time (hotels, guesthouses, villas, etc.) being built, opening themselves towards the sun (terraces, balconies), while traditional buildings preferred shade and compactness. Although it was the time of intensive building of private villas (Lovran, Ika, Opatija), it was also the time of the emergence of large corporations that, in addition to building colonies of villas, also invested in the construction of hotels (e.g., South Railways Company, Lloyd Steamship Company). Large corporations were ready to speculate on land and investment. Another problem was that local governments was not prepared for tourism development and did not develop land (water supply and sewage infrastructure) as an essential precondition for construction. Although war is known to have a substantial impact on tourism, there is almost no research into how wWI influenced tourism development and investments in tourism at that time.

Therefore, the main aim is to show that the Great War had a negative impact on the rapid development of tourism on the Croatian Adriatic coast at the time. The main part of the research relates to finding data about hotels not built due to the outbreak of WW I. Statistical data and architecture and tourism journals emerging during the Austro-Hungarian Empire were used for the research, as well as monographs of individual architects and tourism travel books. To understand the context of the time, the research used statistical data on tourism figures at the level of the AustroHungarian Empire and the level of individual tourist destinations on the Croatian Adriatic and briefly described the most critical tourism-related events.

To ensure an as objective as possible presentation of unbuilt tourism architecture due to the outbreak of $\mathrm{WW} \mathrm{I}$, the paper relies on a series of primary and secondary sources, including tourism statistics, museum and archival material, tourism literature, and literature on architecture and construction.

The research on the impact of the global war becomes more complex if we take into account that the end of the war brought about significant sociopolitical, economic (changes in power centres, new 
territorial divisions, etc.) and cultural changes, so withdrawals from investment projects in tourism were not officially recorded.

Several years after the end of the war, the new states were busy with organising themselves, taking care of the wounded, and tourism was only secondary in importance.

\section{Tourism Opportunities from the End of the 19th Century to the Beginning of WWI}

By bringing the military, security and socio-political situation in south-eastern Europe in order, the AustroHungarian Empire wanted to capitalise on its Riviera in the same way France and Italy had with theirs, although spa tourism was already well-developed in Czech spa towns. ${ }^{3}$

Because the French and Italian Rivieras were recording increasing tourism revenues year after year in the second half of the 19th century, it is not unusual that different investors, as well as the government of the Austro-Hungarian Empire, saw possibilities for tourism development on the east coast the Adriatic Sea (today part of Italian, Slovenian, Croatian, BosnianHerzegovinian and Montenegrin coast).

According to statistics, tourism turnover, as well as the number of designated spa towns (German: Kurorte) in the entire Austro-Hungarian Empire, was growing seemingly unstoppably. ${ }^{4}$ Spa tows were designated according to specific climatic characteristics and strict and specific requirements for a spa.

The growing number of spa towns, not only in the Empire but throughout Europe, required an inventory (Reimer, 1889). Apart from showing basic data about the spa town (short description of the location, number of inhabitants, how to travel there, etc.) and medical characteristics, the inventory helped doctors and patients choose a spa. The inventory of spa towns was

\footnotetext{
${ }^{3}$ In the Austro-Hungarian Empire, area of the present-day Czech Republic recorded highest tourism figures.

${ }^{4}$ The operation of spa towns (German: Kurorte) was under the jurisdiction of the Ministry of the Interior, and some of them lost that status. Therefore, the number of spas in the Empire did not always increase but fluctuated because of the need to meet strict requirements of the Ministry of the Interior.
}

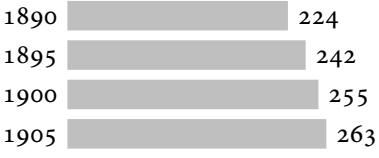

Figure 1 The Number of Spa Towns in the AustroHungarian Empire (adapted from from Statistisches Jahrbuch der Österreichischen Monarchie, 1905, p. xvi)

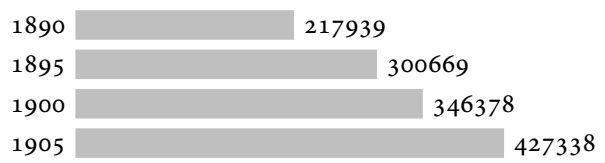

Figure 2 The Number of Spa Guests in the AustroHungarian Empire (adapted from from Statistisches Jahrbuch der Österreichischen Monarchie, 1905, p. xvi)

interesting to (large and small) investors as well when choosing the location for their investment.

In order to attract investors and as many guests as possible, great efforts had been put into promotion. One could read, for example, in travel books and tourist guides that Dalmatia was called 'the land of history and the land of future travels' (Holbach, 1908) or 'a tourism country of par excellence in Austria' (Illustrierted Führer durch Dalmatien, 1912). Small and relatively unknown tourist destinations added a comparison with the world-famous destinations. Thus, Hvar was called the 'Austrian Madeira' and Rab the 'Austrian Venice,' among other examples. The pre-war press in Croatia, such as Sloboda from Split, published articles on tourism development. Thus, Marjanović (1909) discusses tourist arrivals in Dalmatia, the organisation of foreigners' traffic, the organisation for the promotion, public education, rational financing, hotel society, and so on. Marjanović also proposed the establishment of a domestic hotel society - the Croatian hotel society. As the number of spa towns was growing, so did the number of guests in the AustroHungarian Empire.

The east coast of the Adriatic Sea, regardless of its tourism potentials (climate, sea, sun, culture and natural heritage), was the economically undeveloped part of the Austro-Hungarian Empire. The economy 
of Adriatic coast was based on outdated forms of agricultural production, sale of raw materials, and a poorly developed manufacturing industry. The economic crisis (brought on by the collapse of sailing ship construction, the Wine Clause of 1891 and the Phylloxera outbreak, which devastated vineyards in 1894), caused the emigration of the population to overseas countries, primarily of young people from the coastal region and islands. Not to be neglected is the fact that about $90 \%$ of the population was illiterate. With the emigration of the working population, the price of land dropped, which played particularly well into the hands of speculation with land for the construction of buildings for various purposes. Austrian, German, English, and even Czech investors were on the lookout for investment opportunities, inter alia, in tourism.

The development of tourism, and thus the reflection on tourism architecture, was also attributed to the Technische Hoch Schule [Technical High School] in Vienna. Numerous students chose tourism architecture projects on the Croatian Adriatic for their diploma theses (Kranjčević, 2017).

Investments, education, promotion, and technical infrastructure were the topics (among others) discussed at the beginning of the 2oth century. Architects were designing larger and more complex buildings (hotels as well) because guests should be, inter alia, attracted by innovative architecture. All these new types of buildings (hotels, boarding houses, casinos, etc.) were to be built at the local level. Investors often encountered resistance from local municipalities.

\section{Adriatic Exhibition}

To make the Austrian Riviera recognisable as suitable for investments in tourism and to attract as many tourists as possible, the first sizeable thematic exhibition was organised in 1913 in Prater in Vienna on tourism on the east coast of the Adriatic called Adria Ausstellung [Adriatic Exhibition] (Storch, 2013; Kranjčević, 2018a). The exhibition was organised on the model of Internationale Ausstellung für Reise und Fremdenverehr [Travel and Tourism Exhibition] in Berlin in 1911.

The exhibition in Vienna was of international significance. Apart from the presentation of the south- ern Austro-Hungarian Empire, the exhibition was attended by Canada, Italy, Turkey and other countries. ${ }^{5}$ Although the main objectives of the exhibition were to represent the potentials in culture and economy, and thus tourism of the Adriatic region, the educational function of the exhibition should not be neglected. During the exhibition, there were numerous lectures (Adria Ausstellung, 1913) and a conference on tourism Adria Fremdenverkehrkonferenz [Adriatic Conference on Tourism] which discussed, among other things, the problems of building hotels in Dalmatia (i.e., investments in tourism on the east coast of the Adriatic). Two large companies that invested in tourism - Südbahngesellschaft [Austrian Southern Railway] and the Austrian Lloyd, a steamship company - clashed at the conference.

The construction of new hotels often faced numerous problems, primarily of an administrative nature, and investors often found it challenging to obtain construction permits.

Given that investors encountered numerous problems on the Croatian coast of the Adriatic when obtaining construction permits, the Ministry of Public Works presented, at the exhibition, a prototype of the prefabricated hotel Dalmatia which was also used as a catering facility at the exhibition space. The prototype was built with the aim of speeding up the construction of hotels, which often faced problems of administrative nature at the local level. Hotel design included regional design characteristics (Adria Ausstellung, 1913; 'Das Musterhotel in der Adria,' 1913).

Positive reactions to the exhibition are also evident from the fact that it was visited by 2,080,000 visitors over 155 business days (Storch, 2013; Kranjčević, 2018a).

The exhibition generated strong interest for the eastern Adriatic coast by the general public and investors alike, and thus also the Croatian coast, and should have created preconditions for further tourism development on the eastern Adriatic coast. What tourism on the eastern Adriatic coast would have looked

${ }^{5}$ Since the end of the 19th and the beginning of the 2oth century was an era of great technological progress, it was also a time of organising major economic and world exhibitions. 
like had ww not broken out a year after the exhibition can only be assumed.

\section{Ministry of Public Works}

The entire east coast of the Adriatic, owing to its favourable climate, rich cultural, and natural heritage, cheap land for construction and poor economic development, possessed all the prerequisites for tourism development. All statistical data (tourism figures) lead to the conclusion that the end of the 19th and the beginning of the 2oth century was the time of dazzling tourism development.

The Ministry of Public Works also became involved in tourism development as well as in improving economic conditions in Dalmatia. It commissioned architect Alfred Keller (1911 to 1913) to make projects for hotels in Susak, Trogir, Split, Dubrovnik, and Trsteno, and architect Wilhelm Jelinek to make a project for Makarska (Kranjčević, 2013; Kranjčević, 2016a). Hotel projects by Alfred Keller were again discussed during W WI, in 1916 in journals Der Architekt and Wiener Bauindustrie Zeitung (V. F., 1916, 1918), given that these cases did not concern exclusive hotels but rather the category of hotels for the wider public.

His projects were discussed even a decade after the end of the war in the journal Jugoslovenski turizam [Yugoslav tourism] (Ćulić, 1928).

\section{The First Impact of War on Tourism Turnover on the Eastern Adriatic Coast}

Only two and a half weeks after the Austro-Hungarian Empire had officially declared war on Serbia on 28 July 1914, passenger ship traffic on the Adriatic Sea suffered a harsh blow. Baron Gauctsch, a passenger ship sailing on the Trieste-Kotor-Trieste express route, ran into a minefield near the Brijuni Islands on $13 \mathrm{Au}-$ gust 1914. Due to the high number of victims, certain shipping lines were suspended (Tudor, 2007, pp. 33-34). Navigation on the Adriatic Sea became even more unsafe in 1915 when Italy entered the war because Italian submarines and torpedo boats started to attack Austrian-Hungarian ships. Voyage by ship on the Adriatic Sea suffered a significant setback, and tourism-related voyages sharply declined.
Table 1 Number of Registered Tourists in Opatija, Lovran, Mali Lošinj, and Veli Lošinj in 1913, 1914 and 1915

\begin{tabular}{lrrr}
\hline Town & 1913 & 1914 & 1915 \\
\hline Opatija & 49,187 & 41,992 & 7,472 \\
Lovran & 11,915 & 7,899 & - \\
Mali and Veli Lošinj & 8,469 & 5,816 & - \\
\hline
\end{tabular}

Notes Adapted from Blažević (1987).

Table 2 Number of Registered Arrivals of Guests in Dubrovnik, Split, Šibenik, Korčula, Rab, Hvar, and Kotor in 1913 and 1923

\begin{tabular}{lrr}
\hline Town & 1913 & 1923 \\
\hline Dubrovnik with Kupari & 25,700 & 27,924 \\
Split & 41,000 & 27,313 \\
Šibenik & 7,000 & 5,723 \\
Korčula & 1,000 & 1,736 \\
Rab & 3,000 & 4,345 \\
Hvar & 600 & 1,036 \\
Kotor & 7,500 & 983 \\
\hline Total & 85,800 & 69,062 \\
\hline
\end{tabular}

Notes Adapted from Golf (1929). Kotor was part of the Austro-Hungarian Monarchy until 1918, more specifically of the Kingdom of Dalmatia. It is now part of Montenegro.

During the four-year war, about forty vessels owned by Lloyd and other steamship companies were destroyed or damaged on the east Adriatic coast (Tudor, 2007, pp. 33-34). In short, due to unsafe navigation on the Adriatic Sea, the number of passengers on steamers plummeted, resulting in decreased numbers of tourists and overnight stays in tourist destinations.

The decline in tourism turnover could not have recovered for many years after the war (Table 2).

\section{Unbuilt Hotel Projects}

A prerequisite for the construction of hotels and other types of buildings for entertainment and leisure is the construction of transport and technical infrastructure (railways, roads, ports, water supply, sewage, electricity, telephone, etc.). The construction of a hotel is known to be a complex and long-term job because it is necessary to design the project, secure land, build traffic and technical infrastructure, among other en- 


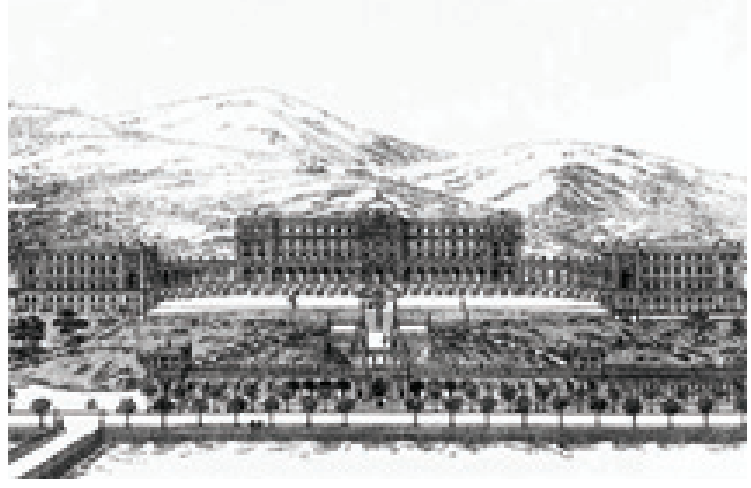

Figure 3 Project for Hotel in Crikvenica (Prokop, 1897, p. 6)

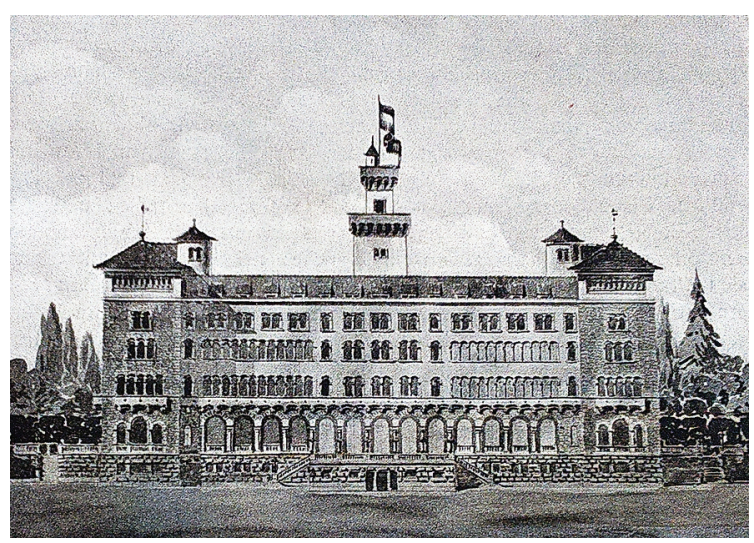

Figure 4 Project for Hotel in Dalmatia, Unknown Location (Band, 1910)

deavours. The Society for Economic Development of Dalmatia, founded in Vienna in 1894 (Piplović, 2011), commissioned architects to prepare hotel projects to attract investors and reduce resistance by municipalities. Numerous reasons exist why some hotel projects remain unbuilt. Some projects were not realised because there were no more interested investors or the investors gave up because the infrastructure was not developed at certain locations. Then, there is also a hotel project by an unknown architect for an unknown location in Dalmatia whose drafting was inspired by the Society for Economic Development of Dalmatia (Band, 1910).

Problems about making a project for hotels often lead to debates in architectural journals (Lux, 1909).
Therefore, just before the Great War, several urban and architectural competitions were held and master plans and architectural projects elaborated, aiming to reconcile the wishes of investors and the possibilities of the local community (Opatija, Rab, Korčula, Lošinj).

Constant increases in the number of tourists called for a corresponding increase in hotel room capacity.

In Opatija, the famous Austro-Hungarian health resort, by the sea, Österreichische Riviera Gesellschaft [Austrian Riviera Society] planned to build a spa hotel palace and announced an architectural competition in 1911/1912. The first prize was awarded to architects Hoppe, Schönthal, and Kammerer in collaboration with Professor Otto Prutscher. The layout area of the spa palace was to be $11,500 \mathrm{~m}^{2}$. As it was a huge investment, only earthworks were carried out while the spa palace-hotel was never built. The size of the investment is evident from the fact that the sea was filled with $79,500 \mathrm{~m}^{2}$ of material to obtain a surface area of 26,000 $\mathrm{m}^{2}$ (Kranjčević, 2016a).

The second unbuilt hotel project in Opatija is a hotel on six floors from 1914 by the already mentioned Viennese architectural trio of Hoppe, Schönthal, and Kammerer. Unlike the previous project, the facade of this hotel was to be simpler, that is, designed more rationally (Boyd Whyte, 1989).

Because of the increase in nautical tourism in Opatija (before WWI), a nautical centre was planned for building by August Belohlavek in 1916 (Belohlavek, 1919). This building was never built.

Likewise, in Dobrika Bay on the island of Veliki Brijun, a hotel project from 1915 by architect Eduard Kramer and investor Paul Kupelwieser also remained unbuilt (Kranjčević, 2016b). This hotel on five floors was designed to have more than 100 rooms, which was a huge investment for Croatia at the time (NP Brijuni).

After an architectural competition was held for the building of a large hotel complex on the island of Rab in 1914, the project by architect Karl Lehrmann went on to be unrealised. Unfortunately, although the first prize was awarded, the project was not realised primarily due to the outbreak of the war (Kranjčević, 2016a).

One particularly interesting unbuilt project on the east coast of the Adriatic Sea is the project by a Berlin 


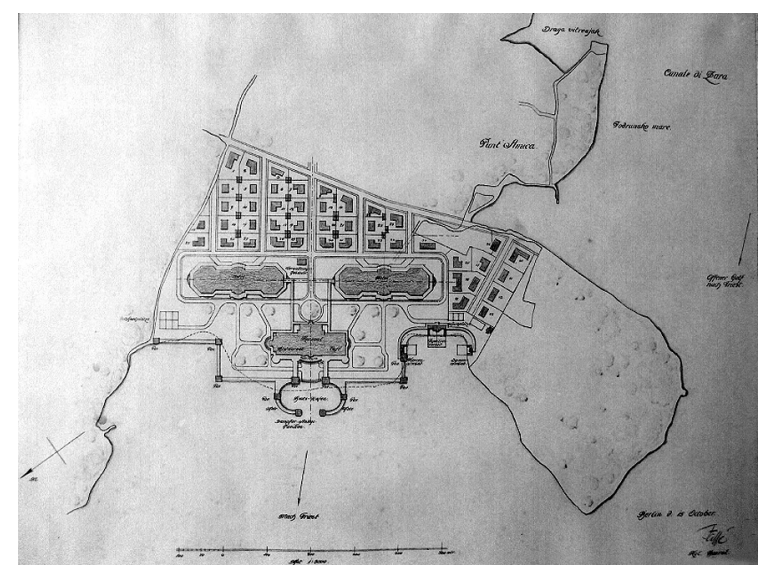

Figure 5 Project for Riviera Zaratina, 1910

consortium for Borik (Puntamika) in Zadar from the first decade of the 2oth century. This project, called 'Riviera Zaratina,' proposed three luxury hotels, a wellequipped sand and bathing space, hotel space specially equipped for guests in winter, maintenance and expansion of green areas with the emphasis on the cultivation of Mediterranean plants.

Sadly, for Lovran (near Opatija), the 1908 project for a multi-purpose stadium (sports competitions, tombola, etc.) remained unbuilt (Fassbender, 1908). This is an indicator that sports facilities were planned for expanding the tourist services offered.

In the continental part of the Empire, discussions were also held on the construction of new hotels in health resorts. For Topusko (continental part of Croatia), an architectural contest was announced in 1910. Since the construction of a hotel requires many years of preparation, the project was not realised.

Research on unbuilt hotels is certainly just one of the segments that can be used to track the impact of WWI at the then turbulent development of tourism.

\section{Military Spa Resorts and Hotels as Hospitals for Wounded Soldiers in World War I}

Along with 'civil' spa houses (Kurhaus) on the east coast of the Adriatic Sea, military spa resorts were also built under the auspices of the White Cross Association. This association built and/or renovated and refurbished military spa resorts in Opatija in 1888 and
Čikat on the island of Lošinj in 1907. During the war, in 1916, a new military spa resort Kaiserin Zita Offizierkurhaus [Empress Zita Spa Resort for Officers] was planned for building, with a larger capacity (60 beds) than the current one ( 16 beds), after a design by architect Alois Wurm Arnkkreuz (Jahrbuch der K. K. Gesellschaft vom Weissen Kreuze, 1917, p. 51).

The recovery of a large number of wounded soldiers and disabled workers required large accommodation facilities, leading to many hotels being converted into military spa resorts. For example, Hotel Liburnia in Kraljevica (built in 1904) and Hotel Emigranti in Rijeka (built in 1908) were converted into a military spa resort/military hospital during the war, as well as some other hotels on the Adriatic Sea.

\section{Discussion and Conclusions}

Had the end of the 19th and the beginning of the 2oth century not been marked by global development of technology, communication, medicine and transportation as well as the surplus of free time, tourism as a new social phenomenon could certainly not have developed. Without a doubt, a great impetus to tourism development at the beginning of the 2oth century came from organised tourism propaganda and thematic tourism or economic exhibitions.

The rise of tourism in the Austro-Hungarian Empire, and thus also on the Croatian Adriatic coast, should be considered in the context of global tourism development, not just through TALC.

There is no doubt that the staggering tourism development before WWI, manifested through a sudden growth in tourism figures, the construction of tourism architecture and traffic, had the features of mass tourism from the very beginnings.

Likewise, there is no doubt that the staggering tourism development before WwI in the world, as well as on the Croatian Adriatic coast, caused the beginning of the spatial transformation of the Croatian Adriatic coast. A constantly increasing number of tourist arrivals called for (demanded) the construction of previously unknown types of buildings, such as hotels, villas, guesthouses, restaurants, and other buildings of tourism architecture that, in turn, required specific infrastructure (electric power stations, a water 
Table 3 List of Some of the Unbuilt Hotel Projects on the Croatian Adriatic Coast

\begin{tabular}{llll}
\hline Towns & Type of hotels & Architect & Investor \\
\hline Crikvenica & Hotel Palace, 1896 & Arnold Lotz (Prokop, 1897) & - \\
Brijuni & Hotel, 1914 & Eduard Kramer & Paul Kupelwieser \\
Dubrovnik & $1911-1913$ & Alfred Keller & $\begin{array}{l}\text { Society for Economic } \\
\text { Development of Dalmatia }\end{array}$ \\
Kupari, Dubrovnik & Hotel Resort & Jiři Stibral and Alois Zima & Czech consortium \\
Lošinj & Spa resort for royal and state & & Alexander Krasza 1909. \\
& officials, 1909 & & \\
Opatija & Hotel Palace 1911/1912. & Hoppe, Schönthal, and & Österreichische Riviera \\
& & Kammerer & Geselschaft \\
& Hotel 1914 & Hoppe, Schönthal, and & - \\
Rab & Nautical Centre, 1916 & Kammerer & \\
Makarska & Johel Resort & Karl Lehrmann August Belohlavaek & - \\
Split & Hotel, 1911-1913 & Wilhelm Jelinek & - \\
Susak & Hotel Palast, 1911-1913 & Alfred Keller & Society for Economic \\
Trogir & Spa hotel (kurhaus) & Alfred Keller & Development of Dalmatia \\
Trsteno & Hotel, 1911-1913 & Alfred Keller & Ministry of Public Works \\
& Tourist Resort (hotel and villas) & Alfred Keller & Ministry of Public Works \\
Unknown location & Hotel for Dalmatia & From book (Band, 1910) & Ministry of Public Works \\
Unknown location & Prototype of the hotel Dalmatia & Adriatic exh. in Vienna 1913 & Society for Economic \\
Zadar & Riviera Zaratina 1904 & T. Jaffé & Development of Dalmatia \\
\hline & & & German consortium \\
\hline
\end{tabular}

supply network, roads, a railway network, parks, etc.). Numerous destinations put significant effort into being known on the tourism market.

The issue of new trends in shaping tourism architecture on a global scale before ww i became increasingly pronounced. The inflow of capital into the tourism sector required ever faster and simpler construction, ${ }^{6}$ as tourism encompassed increasingly wider layers of society.

Although the Croatian coastal area was economically underdeveloped, from the end of the 19th and

${ }^{6}$ As new time demanded a new approach to architecture, it is not unusual for Adolf Loos to publish essays 'Ornament and Crime' 1906-1909 in which he advocated building buildings without ornamentation. at the beginning of the 2oth century, tourism together with planned industry and agriculture development was supposed to facilitate its modernisation, and the coast was to become a serious competitor to Italian and French tourism (Piplović, 2011).

The suspension of investment at the beginning of World War I referred not only to the construction of hotels but also to the construction of the railway network, ports, and other facilities used in tourism.

Investments in tourism required attractive locations for which adequate land and labour force had to be secured, and therefore their realisation certainly required time. Quite quickly, the narrow coastal strip become a large construction site. Wwi did not put a stop to tourism development only on the coast, but also in the continental part of Croatia. 
Given the boom in tourism on the Croatian coast in the early 20 th century, World War I as a global event heavily impacted investments in tourism and, in turn, in the economy. This interruption in the development of tourism undoubtedly influenced the change in the relationship between tourism and space.

We can only hypothesise as to what the Croatian coast would have looked like had at least the majority of the presented hotels been built. The Croatian Riviera would have certainly appeared different than it does now, and the attitude towards tourism would have undoubtedly been different as well.

This means that TALC cannot be observed only through the prism of the destination, but should be viewed through the prism of the impact of global changes that have had a substantial impact on the history of tourism, changes in trends in tourism (supply and demand), the development of destination tourism and thus also on tourism architecture.

Although at the beginning of the 2oth century, there were indications of changes in architectural design and thus the design of tourism architecture, the approach to tourism architecture design undoubtedly changed after wWI.

While archival material about unbuilt tourism architecture was viewed here as material for considering the impact of global changes on tourism, undoubtedly this archival material may be used to contribute to the rethinking of this material as architectural tourism heritage and presentation of this type of heritage.

Tourism recovery on the Croatian coast after w w I was relatively slow. While there is archival material about unbuilt tourism architecture as a resource for reflecting on the impact of global changes on tourism, this material can serve as a contribution to the rethinking of this material such as architectural tourism heritage and presentation of this type of heritage.

\section{Acknowledgments}

This work has been supported in part by the Croatian Science Foundation under the project HERU-2032.

Any opinions, findings, and conclusions or recommendations expressed in this material are those of the author and do not necessarily reflect the views of the Croatian Science Foundation.

\section{References}

Adria Ausstellung. (1913). Der Fremdenverkehr, 6(19), 11.

Band, M. (1910). Dalmatien - das Land der Sonne, eine Wanderfahrt an der Adria. Vienna, Austria: Hartleben.

Band, M. (1914). Der Krieg und der Fremdenverkehr. Der Fremdenverkehr, $7(33), 1$.

Baranowski, S., \& Furlough, E. (2001). Being elsewhere: Tourism, consumer culture and identity in modern Europe and North America. Ann Arbor, Michigan: University of Michigan Press.

Belohlavek, A. (1919). Projekt für ein Schiffahrtsaufnahmgebäude am Molo in Abazzia. Wiener BauindustrieZeitung, 34(6), 44-45.

Berghoff, H., Korte, B., Schneider, R., \& Harvie, C. (Eds.). (2002). The making of modern tourism: The cultural history of the British experience, 1600-200o. London, England: Palgrave.

Blažević, I. (1987). Povijest turizma Istre i Kvarnera. Opatija, Croatia: Otokar Keršovani.

Boyd Whyte, I. (1989). Emil Hoppe, Marcel Kammerer, Otto Schönthal - Drei Architekten aus der Meisterschule Otto Wagners. Berlin, Germany: Ernst.

Butler, R. W. (1980). The concept of tourism area cycle of evolution. Canadian Geographer, 24(1), 5-12.

Butler, R., \& Suntikul, W. (Eds.). (2013). Tourism and war. London, England: Routledge.

Čorak, S., Mikačić, V., \& Ateljević, I. (2012). An ironic paradox: The longitudinal view on impacts of the 1990 s homeland war on tourism in Croatia. In R. Butler \& W. Suntikul (Eds.), Tourism and War (pp. 161-175). London, England: Routledge.

Ćulić, J. (1928). Način za rješenje problema naših pasivnih krajeva - historijat akcija za podizanje hotela u Dalmaciji. Jugoslovenski turizam, 1(2), 5-7.

Das Musterhotel in der Adria. (1913). Der Fremdenverkehr, $6(21), 10-12$.

Dragičević, M., Nikšić Radić, L., \& Grbić, L. (2018). Terrorism as security challenge in tourism development. In I. Milohnić \& J. D. Smolčić (Eds.), Tourism and hospitality industry 2018 (pp. 64-75). Opatija, Croatia: Faculty of Tourism and Hospitality Management.

Fassbender, E. (1908). Die österreichische Riviera in baulicher hinsicht. Zeitschrift des österrreichischen Ingenieur und Architekten Verein, 6o(28), 449-452.

Flückinger-Seiler, R. (2003). Hotel Paläste, zwischen Traum und Wirklickeit, schweizer Tourismus und Hotelbau 18301920. Baden, Germany: Hier + Jetzt.

Frey, B. S. (2004). Dealing with terrorism: Stick or carrot? Cheltenham, England: Edward Elgar Publishing. 
George, E. W., \& Das, M. (2017). Remembering World War I: Memory influences and impact on intentions to visit war heritage sites. Journal of Tourism \& Hospitality, 6(2), $1-10$.

Gillena, J., \& Mostafanezhadb, M. (2019). Geopolitical encounters of tourism: A conceptual approach. Annals of Tourism Research, 75, 70-78.

Golf, L. (1929). Razvoj turizma (planinarstva saobraćaja putnika) u Dalmaciji. Split, Croatia: Primorsko planinarsko društvo Dinara u Splitu.

Holbach, M. M. (1908). Dalmatia, the land where East meets West. London, England: J. Lane.

Illustrierted Führer durch Dalmatien. (1912). Vienna, Austria: A. Hartleben's Verlag.

Jadrešić, V., \& Jurić, B. (1985). Turizam Zadarskoga kraja. Zadar, Croatia: Turistički savez općine Zadar.

Jahrbuch der K. K. Gesellschaft vom Weissen Kreuze. (1917). Vienna, Austria: Author.

Kavrečič, P. (2016). Obiskovanje spomenikov prve svetovne vojne. Retrieved from https://mpra.ub.uni-muenchen.de /62843/1/MPRA_paper_62842.pdf

Keck, H. (2008). Skriptum Temporäres Wohnen. Vienna, Austria: TU Wien.

Koshar, R. (Ed.). (2002). Histories of leisure. Oxford, England: Berg Publishers.

Kranjčević, J. (2013). Arhitektonski opus Alfreda Kellera na Kvarneru. Prostor, 21(1(45)), 158-169.

Kranjčević, J. (2016a). Čeští arhitekti a turistika. In T. Goryczka \& J. Němec (Eds.), Čeští arhitekti a počátky turistiky na Chorvatském Jadranu (pp. 13-87). Zagreb, Croatia: Institute for Tourism; Ostrava, Czech Republic: Kabinet Architectury.

Kranjčević, J. (2016b). Unbuilt architectural hotel designs and ideas on the Adriatic Coast in the period until 1918. In G. Crnković \& N Babić (Eds.), Fragments of inetrrupted time - unbuilt projects of tourist architecture (pp. 10-49). Rijeka, Croatia: Hrvatski muzej turizma i Državni arhiv Rijeka.

Kranjčević, J. (2017). Studenti arhitekture u Beču i vizije turizma na hrvatskom Jadranu. Godišnjak njemačke zajednice/DG Jahrbuch, 24, 87-102.

Kranjčević, J. (2018a). Hrvatska obala na Jadranskoj izložbi u Beču 1913. Godišnjak njemačke zajednice/DG Jahrbuch, $25,83-97$.

Kranjčević, J. (2018b). Utjecaj Prvoga svjetskog rata na turizam istočne obale Jadrana - neizvedeni hotelski projekti. In L. Šeput (Ed.), 1914. Prva godina rata $u$ trojednoj kraljevini i Austro-Ugarskoj Monarhiji (pp. 645-662). Zagreb, Croatia: Matica hrvatska.
Krauss, M. (1915). Krieg und Fremdenverkehr. Munich, Germany: Author.

Krauss, M. (1918). Die Wiederaufrichtung des Fremdenverkehrs nach dem Kriege. Munich, Germany: Author.

Krauss, M. (1923). Krisis im Fremdenverkehr. Munich, Germany: Gerber.

Lisle, D. (2000). Consuming danger: Reimagining the war/ tourism divide. Alternatives, 25(1), 91-116.

Lux, J. A. (1909). Das Hotel, ein Bauproblem. Der Architekt, 15(1), 17-20.

Mansfeld, Y., \& Pizam, A. (2006). Tourism, terrorism, and civil unrest issues. In Y. Mansfeld \& A. Pizam (Eds.), Tourism, security and safety (pp. 29-31). Oxford, U K: Elsevier.

Marjanović, M. (1909). Promet stranaca u Dalmaciji. Sloboda, 5(3), 8-9.

Pederin, I. (1991). Jadranska hrvatska u austrijskim $i$ njemačkim putopisima. Zagreb, Croatia: Nakladni zavod Matice Hrvatske.

Perić, I. (1983). Razvitak turizma u Dubrovniku i okolici od pojave parobrodarstva do 1941. godine. Dubrovnik, Croatia: Zavod za povijesne znanosti i istraživačkog centra Jugoslavenske akademije znanosti i umjetnosti.

Petermann, R. E. (1899). Illustrierter Führer durch Dalmatien. Retrieved from https://archive.org/stream/ fuhrerdurchdalmaoopeteiala\#page/412/mode/2up/ search/Lissa

Petermann, R. E. (1915). Wirkungen des Krieges auf Natur und Landschaft, Touristik und Fremdenverkehr. Österreichische Touristen-Zeitung, 35(7), 90-94.

Petrić, M. (2018). Hrvatski turistički spomenar - sentimentalno putovanje kroz turističku prošlost Hvara. Hvar, Croatia: Tz Hvara.

Piplović, S. (2011). Rad na gospodarskom unaprjeđenju Dalmacije na prijelazu 19. u 2o. stoljeće. Godišnjak njemačke zajednice/D G Jahrbuch, 18, 199-228.

Prokop, A. (1897). Über österreichische Alpen-Hotels mit besonderer Berücksichtigung Tirol's. Vienna, Austria: Author.

Reimer, H. (1889). Handbuch der speciellen Klimatotherapie und Balneotherapie mit besonderer Rücksicht auf Mittel-Europa zum Gebrauch für Aerzte. Berlin, Germany: Reimer.

Richard, G. (2003). Tourist's perceptions of safety and security while visiting Cape Town. Tourism Management, 24(5), 575-585.

Schindler, R. (1912). Die Entwicklung des Fremdenverkehrs in Dalmatien. Moderne Illustrierte Zeitung Sport und Reise, 8, 17-22. 
Statistisches Jahrbuch der Österreichischen Monarchie. (1905). Vienna, Austria: Kaiserlich-Königliche Hof- und Staatsdruckerei.

Storch, U. (2013). Der Süden ist eine Haltestelle unserer elektrischen Geworden. Die Adria-Ausstellung 1913. In C. Rapp \& N. Rapp-Wimberger (Eds.), Österreichische Riviera: Wien entedckt das Meer (pp. 160-169). Vienna, Austria: Wien Museum/Czernin Verlag.

Šale, M., \& Pavlović, M. (2004). 100 godina turizma u Baški. Baška, Croatia: Turistička zajednica općine Baška.

Tissot, L. (Ed.). (2003). Construction of a tourism industry in the 19th and 2oth century: International perspectives. Neuchatel, Switzerland: Alphil.

Tudor, G. (2007). Parobrodarstvo i turizam u Dalmaciji. Split, Croatia: Hrvatski pomorski muzej.

Urlić, V. (2008). Počeci turizma u Makarskoj i Primorju do 1940. Makarska, Croatia: Gradski muzej Makarska.

V. F. (1916). Alfred Kellers Hotelprojekte für Dalmatien. Der Architekt, 21, 58-64.

V. F. (1918). Alfred Keller, Österreichische Bauzeitung. Wiener Bauindustrie-Zeitung, 35(11), 81-84.
Vasko-Juhász, D. (2006). Die Südbahn, Ihre Kurorte und Hotels. Vienna, Austria: Böhlau Verlag.

Vukonić, B. (2005). Povijest hrvatskog turizma. Zagreb, Croatia: Prometej.

Walton, J. K. (Ed.). (2005). Histories of tourism: Representation, identity and conflict. Clevedon, English: Channel View Press.

Walton, J. K. (2009). Prospects in tourism history: Evolution, state of play and future developments. Tourism Management, 3o(6), 783-793.

Winter, C. (2009). Tourism, social memory and the Great War. Annals of Tourism Research, 36(4), 607-626.

Zakošek, B. (2005). Opatijski album: Dugo stoljeće jednog svjetskog lječilišta. Rijeka, Croatia: Državni arhiv u Rijeci.

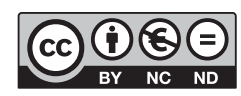

This paper is published under the terms of the Attribution- NonCommercial-NoDerivatives 4.0 International (CC BY-NC-ND 4.0) License. 



\title{
Examining the Seasonality of Travel-Related Expenditure by Travel Purpose: The Case of Japan
}

\author{
Kenichi Shimamoto \\ Konan University, Hirao School of Management, Japan \\ ken_japan51@hotmail.com
}

Addressing seasonality for the travel industry has been a challenge for many tourist destinations. Japan is no exception, and with its recent focus on developing into a tourism nation, it has become even more critical to understand seasonality trends. Methods to address seasonality, such as differential pricing, diversified attraction, market diversification, and facilitation by the state will require the segmentation of the market to form appropriate strategies. Therefore, to provide insight into the seasonality of different markets, this paper categorises the travel-related expenditure into six consumption items for three travel purposes: holiday travel, visiting friends and relatives (VFR) travel, and business travel. It examines the trends and characteristics of the seasonality and the fluctuation across the fiscal years from 2010 to 2017 for domestic travel in Japan. The results show that amongst all three travel purposes, the consumption items with relatively low seasonality and fluctuation across the observation period with stable highest and lowest expenditure months over the years, are shopping/travel gifts expenditure for holiday travel; transportation and food/drink expenditure for VFR travel; and transportation expenditure for business travel. In contrast, the consumption items across the travel purposes with relatively significant seasonality and inconsistent highest and lowest expenditure months over the years are package holidays/tours expenditure and attraction/entrance expenditure for VFR and business travel; and accommodation expenditure for business travel.

Keywords: tourism seasonality, consumption items, travel purpose, Japan https://doi.org/10.26493/2335-4194.12.55-72

\section{Introduction}

Tourism is an attractive industry with the significant impact it can have on the economy through not only the additional income but also the effect it can have on a wide range of industries. Japan has been introducing policies to encourage inbound travel alongside the reinforcement of domestic tourism by Japanese residents with the aim of becoming a tourism nation.

One phenomenon that has been widely studied is the seasonality aspect of tourism. The influential work by Bar-On (1975) provides a comprehensive study of 16 countries over 17 years. Bar-On (1975) and Hartmann (1986) identify the leading causes of seasonality as nat- ural factors and institutional factors. Natural factors include climate, such as the duration of daylight, as well as the amounts of sunshine, rain, and snow, which are difficult to overcome (Hartmann, 1986; Lundtorp, Rassing, \& Wanhill, 1999). Institutional factors include public and school holidays, which are affected by social factors, such as religion and culture (Hartmann, 1986; Allcock, 1989; Butler, 1994; 2001; Hinch \& Jackson, 2000). Butler and Mao (1997) suggest that the ageing society may affect seasonal patterns in the future since they are less restricted in planning their travels. This is identified in a number of literature resources as an essential segment for countries, such as Sweden 
(Gustafson, 2002) and areas such as southern Europe (Williams, King, Warnes, \& Patterson 2000).

The adverse effects of tourism seasonality on the economy have also been researched (Bar-On, 1975; Murphy, 1981; Go, 1990; Lockwood \& Guerrier, 1990; Snepenger, Houser, \& Snepenger, 1990; Faulkner \& Tideswell, 1997). Some of the economic impacts of having an off-peak and peak times are the underutilisation and the overuse of the available capacity, which affects employment and capital investment (Nadal, Riera-Font, \& Rossello, 2004). The inefficient use of resources and facilities often causes loss of profit (Sutcliffe \& Sinclair, 1980; Manning \& Powers, 1984), and the heavy reliance on the business during the peak seasons makes it difficult to attract investors from the private sector, which then may require public support (Mathieson \& Wall, 1982). The impact on accommodation and occupancy rate has also been discussed (Jeffrey \& Barden, 1999; Jeffrey, Barden, Buckley, \& Hubbard, 2002; Fernández-Morales \& Mayorga-Toledano, 2008; De Cantis, Ferrante, \& Vaccina, 2011). The seasonality impact on employment has been frequently studied (e.g., Ball, 1988; Aswhorth \& Thomas, 1999; Krakover, 2000; Jolliffe \& Farnsworth, 2003; Getz \& Nilsson, 2004).

There are also the social-cultural effects on tourists and host destinations. Peak periods can cause congestion and overcrowding of facilities, increase costs, and reduce the quality of services, which impacts both tourists and local residents (Hinch \& Jackson, 2000; Kennedy \& Deegan, 2001). A higher number of people could also lead to an increase in crime during peak seasons (Mathieson \& Wall, 1982). Extra facilities and services such as public toilets, parking, and police may be required. In this way, it has been argued that the socio-cultural impacts put a strain on the social carrying capacity (Manning \& Powers, 1984). There are similar arguments concerning the environmental impacts during the peak time, which could also impact the carrying capacity of the environment (Manning \& Powers, 1984).

Considering the broad impact that seasonality has on the economy, society, and the environment and that the need to forecast tourism requires the understanding of the stability or instability of seasonality, there are extensive studies that measure it to understand the trends across many tourist destinations. For example, Fernandez-Morales, Cisneros-Martinez, and McCabe (2016) examine the seasonality of the number of tourists in the $\mathrm{UK}$ by using the Gini coefficient. Duro (2016) analyses the trend of the seasonality of the number of overnight stays in Spain, also by utilising the Gini coefficient. Coshall, Charlesworth, and Page (2015) examine the inbound tourists' trend for VFR travel and holiday travel in Scotland. Moreover, Juganaru, Aivaz, and Juganaru (2017) investigate the seasonality trends, comparing Romania and other EU countries, applying the mobile average method and Struck method, for travel with overnight stays. A recent study on tourism seasonality in Spain by TurriónPrats and Duro (2018) examines the impact of prices, exchange rates, and income levels.

In these examples, studies on seasonality have been conducted for various regions. However, the seasonality study focused on Japan is not well documented except for the study by $\mathrm{Oi}(2013 ; 2016)$. Oi (2016) analyses the seasonality trends for domestic travel, examining the number of tourists by categorising them into occupational segments. Studying the number of overnight stays, Oi (2013) analyses the seasonality and identifies two types of tourists: tourists with the high motivation of leisure travel and tourists with the low motivation of leisure travel for each region of Japan.

Possible solutions to address tourism seasonality have also been well documented in previous studies. The strategies to address seasonality impacts summarised by Lee, Bergin-Seers, Galloway, O’Mahony, and McMurray (2008) are differential pricing, diversified attraction, market diversification, and facilitation by the state. Differential pricing includes the introduction of seasonal or promotional prices or offers to increase or discourage visitation (Commons \& Page, 2001; Jang, 2004; Jeffery \& Barden, 1999). Butler (2001) suggests the closure of businesses during offpeak season to reduce operational costs. Suggestions for diversified attraction include the hosting of festivals and events, such as sports in low seasons or the development of new attractions and facilities (Witt \& Moutinho, 1995; Higham \& Hinch, 2002; Goulding, Baum, \& Morrison, 2004). Off-season holiday pack- 
ages and complementary offers and diversifying into niche products or services are also suggested (Jeffery \& Barden, 1999; Witt \& Moutinho, 1995; Goulding et al., 2004; Jang, 2004). Approaches identified for market diversification include marketing campaigns to attract different markets during different periods (Witt \& Moutinho, 1995), the determination of the optimal segment mix (Jang, 2004) and aligning with tour operators and travel agents (Jeffery \& Barden, 1999). Areas recommended for facilitation by the state include the staggering of holidays, initiatives to increase and encourage flexibility in the labour market, and the provision of financial support such as loans, subsidies and tax concessions (Witt \& Moutinho, 1995; Goulding, et al., 2004; Krakover, 2000; Baum \& Hagen, 1999).

To develop such strategies, the segmentation of the market will be necessary. Therefore, in order to provide insight into the seasonality of the different markets, this paper categorises the travel-related expenditure into consumption items for holiday travel, VF R travel and business travel. The most frequent measurement unit of seasonality is the number of visitors (Lundtorp, 2001). Other units include the number of arrivals or departures, the number of overnight stays, the length of stay, and the expenditures of the visitors (Koc \& Altinay, 2007; Karamustafa \& Ulama, 2010; Duro, 2018; Šegota \& Mihalič, 2018). However, seasonality research based on a range of travel-related expenditures is limited.

For Japan, such studies do not exist and, to the best of my knowledge, a study of the seasonality on the different types of travel purpose has not been conducted. This paper applies several methods to examine the trends and characteristics of the seasonality and the fluctuation across the fiscal years between 2010 and 2017 for domestic travel in Japan. It also examines the consistency of the highest and lowest expenditure months over the observation period for each consumption item and travel purpose.

The structure of this paper is as follows. The next section will describe the methods and data, and in the third section, we will analyse the seasonality and the fluctuation and the consistency of the highest and lowest expenditure months across the fiscal years for each travel purpose and each consumption item. The fourth section will summarise the main results, followed by a discussion section regarding policy implications. The conclusion is provided at the end.

\section{Methods and Data}

The data applied are the domestic travel-related expenditure by Japan residents for each consumption item for each type of travel purpose from the Japan $\mathrm{Na}$ tional Tourism Survey from the Japan Tourism Agency for the period from 2010 to 2017 (http://www.mlit .go.jp/kankocho/siryou/toukei/shouhidoukou.html?). The Japan National Tourism Survey is a survey sent twice a year to a random sampling of 2.5 million residents in Japan (from the Basic Residents Registry). The total domestic travel expenditure is obtained by the sum of the domestic travel expenditure with overnight stays and the domestic travel expenditure without such stays. There are three travel purposes identified: holiday, vfR, and business. The six consumption items for the travel expenditures are: package holiday and tours expenses (package); transportation expenses (transportation); accommodation expenses (accommodation): food and drink expenses (foodઐdrink); shopping and 'omiyage (travel gifts)' expenses (souvenir); and entrance and attraction expenses (attraction).

As an indicator for seasonality, the coefficient of variation $(\mathrm{Cv})$ will first be adopted. The $\mathrm{CV}$ is calculated by dividing the standard deviation with the mean in order to address the problem in which the variance depends on the mean. Thus, the equation is as follows.

$$
\mathrm{CV}=\frac{1}{{ }_{i}^{p} \mu_{t}} \sqrt{\frac{1}{n} \sum\left({ }_{i}^{p} y_{m, t}-{ }_{i}^{p} \mu_{t}\right)^{2}}=\frac{{ }_{i}^{p} \sigma_{t}}{{ }_{i} \mu_{t}} .
$$

$i$ refers to each consumption item. $p$ denotes the purpose of travel, which is classified as holiday, VFR, and business. $m$ represents months. $t$ is fiscal year, ${ }_{i}^{p} y_{m, t}$ is the domestic travel-related expenditure by Japan residents for a given month of a fiscal year for a specific consumption item for each travel purpose. ${ }_{i}^{p} \mu_{t}$ represents the mean monthly domestic travel-related expenditure by Japan residents for a specific fiscal year for each consumption item by travel purpose. $n$ represents the number of months. 
As the second indicator of seasonality, the standard deviation of logarithms (SDL) will be utilised. The equation is as follows.

$$
\mathrm{SDL}=\sqrt{\frac{1}{n} \sum\left(\ln _{i}^{p} y_{m, t}-\ln _{i}^{p} \mu_{t}\right)^{2}} .
$$

The logarithmic conversion enables an analysis of fluctuations between months with low expenditure. This indicator is also not dependent on a unit since it is free from absolute values.

As the third indicator, we adopt the relative mean deviation (RMD), which can be represented as follows.

$$
\mathrm{RMD}=\left.\frac{1}{n_{i}^{p} \mu_{t}} \sum\right|_{i} ^{p} \mu_{t}-{ }_{i}^{p} y_{m, t} \mid .
$$

The numerator of the right-hand side of equation (3) represents the difference between ${ }_{i}^{p} y_{m, t}$, the domestic travel-related expenditure by Japan residents for a given month of a fiscal year for a specific consumption item for each travel purpose and ${ }_{i}^{p} \mu_{t}$, the mean monthly domestic travel-related expenditure by Japan residents for a given fiscal year for each consumption item for each travel purpose, which is measured in absolute values. As in the case with $\mathrm{CV}$, in order for the indicator to not depend on the mean, it is divided by ${ }_{i}^{p} \mu_{t}$. Therefore, this represents the relative dispersity of domestic travel-related expenditure by Japan residents, which is measured in absolute values. If the domestic travel-related expenditure for Japan residents each month is equivalent, then the indicator is o. In contrast, if the expenditure for one month completely makes up the entire annual expenditure, the indicator will be $2(n-1) / n$. Thus, the smaller the indicator, the smaller the dispersity between the months. However, since this indicator relies on the absolute value difference of the monthly travel-related expenditure and the mean monthly travel-related expenditure, it is unresponsive to changes amongst months taht are above or below the mean (Sen, 1973).

The fourth indicator applied to overcome this challenge is the Gini coefficient. The indicator is defined as follows. Suppose that the number of months in a year is, $n$, the domestic travel-related expenditure by Japan residents for a given month of a fiscal year for a specific consumption item for each travel purpose is ${ }_{i}^{p} y_{m, t}$ and the mean monthly domestic travel-related expenditure by Japan residents for a given fiscal year for each consumption item by travel purpose is ${ }_{i}^{p} \mu_{t}$. Then, the order from the smallest monthly expenditure would be, i.e. ${ }_{i}^{p} y_{m=1 s t, t} \leq{ }_{i}^{p} y_{m=2 n d, t} \leq{ }_{i}^{p} y_{m=3 r d, t} \cdots$. From the above, the Gini coefficient is represented as follows.

$$
\text { GINI }=\frac{1}{2 n^{2}{ }_{i}^{p} \mu_{t}} \sum \sum P_{i}^{p} y_{m, t}-{ }_{i}^{p} y_{l, t} \mid .
$$

Here, the Gini coefficient represents the ratio between the mean annual domestic travel-related expenditure and the mean of the absolute value difference between travel-related expenditures of two randomly selected months, $m, l$. Based on this indicator, if the distribution of the domestic travel-related expenditure for each month is entirely equivalent, GINI is o. In contrast, if the domestic travel-related expenditure is concentrated in one month and the other $n-1$ months have no expenditure, GINI becomes 1 . The characteristic of the Gini coefficient is its sensitivity to central observations, giving greater weight to changes that occur in the months situated around the mode of monthly distribution (Duro, 2016; Turrión-Prats \& Duro, 2018).

Next, as the indicator of seasonality, the Theil index, which incorporates the entropy concept to information theory, is applied. The index utilises the characteristics that the maximum value of entropy is attained by a uniformly distributed random variable. According to this index, the larger the difference between the maximum value and the entropy of the domestic travel-related expenditure is, the larger the dispersity. The Theil index can be represented as follows.

$$
\begin{aligned}
\mathrm{TI} & =\frac{1}{n} \sum \frac{{ }_{i} y_{m, t}}{{ }_{i}^{p} \mu_{t}}\left(\ln \frac{{ }_{i}^{p} y_{m, t}}{{ }_{i}^{p} \mu_{t}}\right) \\
& =\frac{1}{n} \sum{ }_{i}^{p} \mu_{t} \ln \frac{1}{{ }_{i} \mu_{t}}-\sum{ }_{i}^{p} y_{m, t} \ln \frac{1}{{ }_{i}^{p} y_{m, t}} .
\end{aligned}
$$

\section{Results}

Seasonality for Each Consumption Item by Travel Purpose

For each travel purpose, seasonality will be examined for each consumption item for each of the fiscal years 

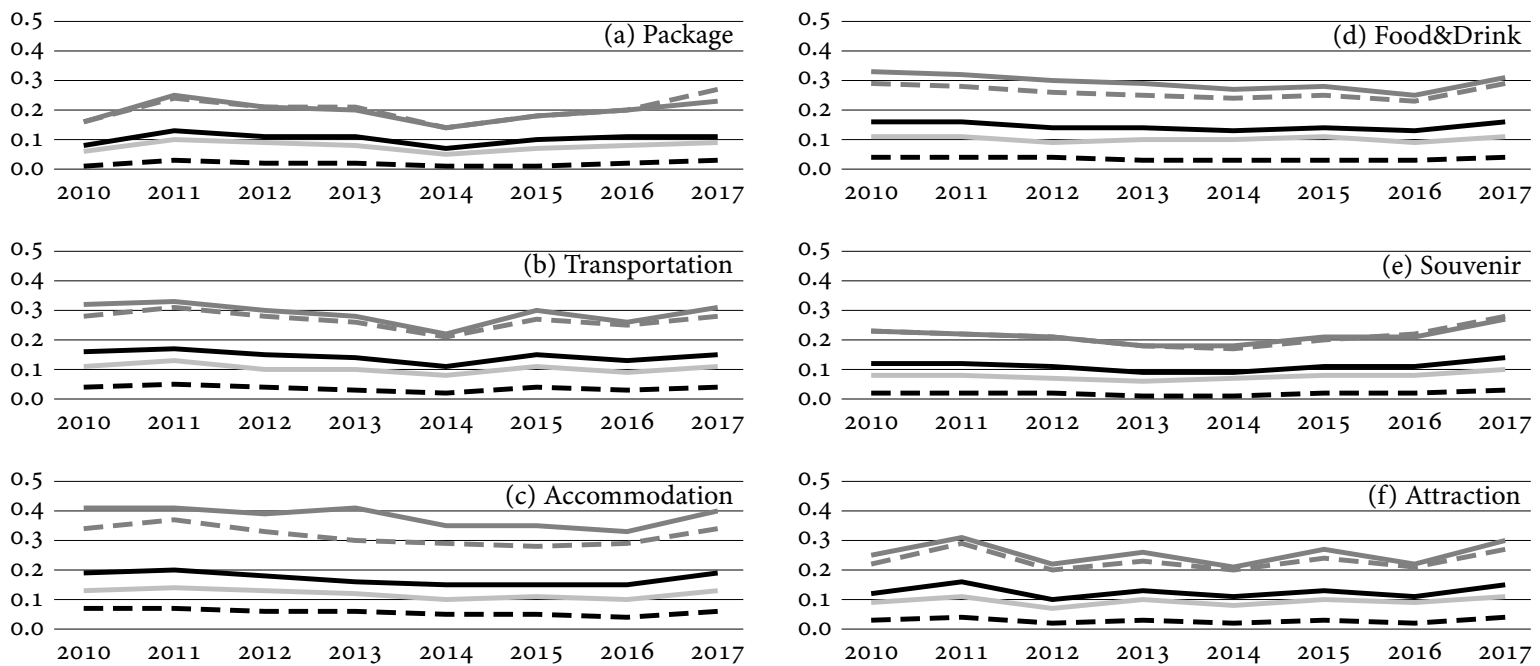

Figure 1 Seasonality Fluctuation for Holiday Travel

Notes Light gray - relative mean deviation, dark gray - coefficient of variation, dark gray dashed - standard deviation of logs, black - Gini coefficient, black dashed - Theil entropy measure.

observed. The seasonality indicator results from each analysis will be examined in the following figures. The first travel purpose reviewed is holiday travel. Figure 1(a) shows that, regarding package for holiday travel, most indicators peak in 2011 and then decrease until 2014, followed by a gradually increasing trend. Next, from Figure 1(b), the transportation results show that all indicators slightly peak in 2011 and gently decrease until 2014, followed by an increase and decrease for every other year. Figure $1(\mathrm{c})$ indicates that for accommodation, most indicators slightly decline from 2011 to 2016 and then increase in 2017. Figure $1(\mathrm{~d})$ indicates that all indicators for foodedrink show a modest decline and then an increase in 2017. The results for souvenir in Figure $1(\mathrm{e})$ show a gentle $\mathrm{U}$ shape for almost all indicators. The overall fluctuations are not large. Figure 1(f) indicates that for attraction the fluctuations between the years are rather large, with all indicators increasing and decreasing every other year.

Next, with regards to VFR travel, the results for each consumption item are as follows. Figure 2(a) shows that for package, most indicators drop in 2011 and then peak in 2013 and 2016, indicating large fluctuations in the seasonality across the fiscal years. Next, from Figure 2(b), the results for transportation show limited fluctuations for all indicators except for increases in 2017. Figure 2(c) indicates a declining trend for accommodation with large fluctuations for most indicators. Figure 2(d) shows that most indicators for food\&drink show slight fluctuations with increases in 2017. For most souvenir indicators, Figure 2(e) shows some small fluctuations over the years, with increases in 2017. Figure 2(f) indicates that all indicators for attraction decline in 2011 and peak in 2012 and 2015 and most remain flat after that.

Finally, we will review the trends for business travel. The indicators for package in Figure 3(a) show gentle inverted U shapes with peaks in 2012 and declines ending in 2014. They then increase for most indicators. Moreover, the fluctuations in seasonality over the observation period are large. Next, from Figure 3 (b), the results for transportation show gradual increasing trends for most indicators, though the seasonality fluctuations over the years are very small. Figure 3 (c) shows large fluctuations across the years for accommodation with drops in 2011 and 2014 and peaks in 2013 and 2016 for all indicators. Figure 3(d) indicates that for foodedrink almost all indicators show gradual increasing trends with peaks in 2014. Figure $3(e)$ indicates that for souvenir, all indicators show a slight 

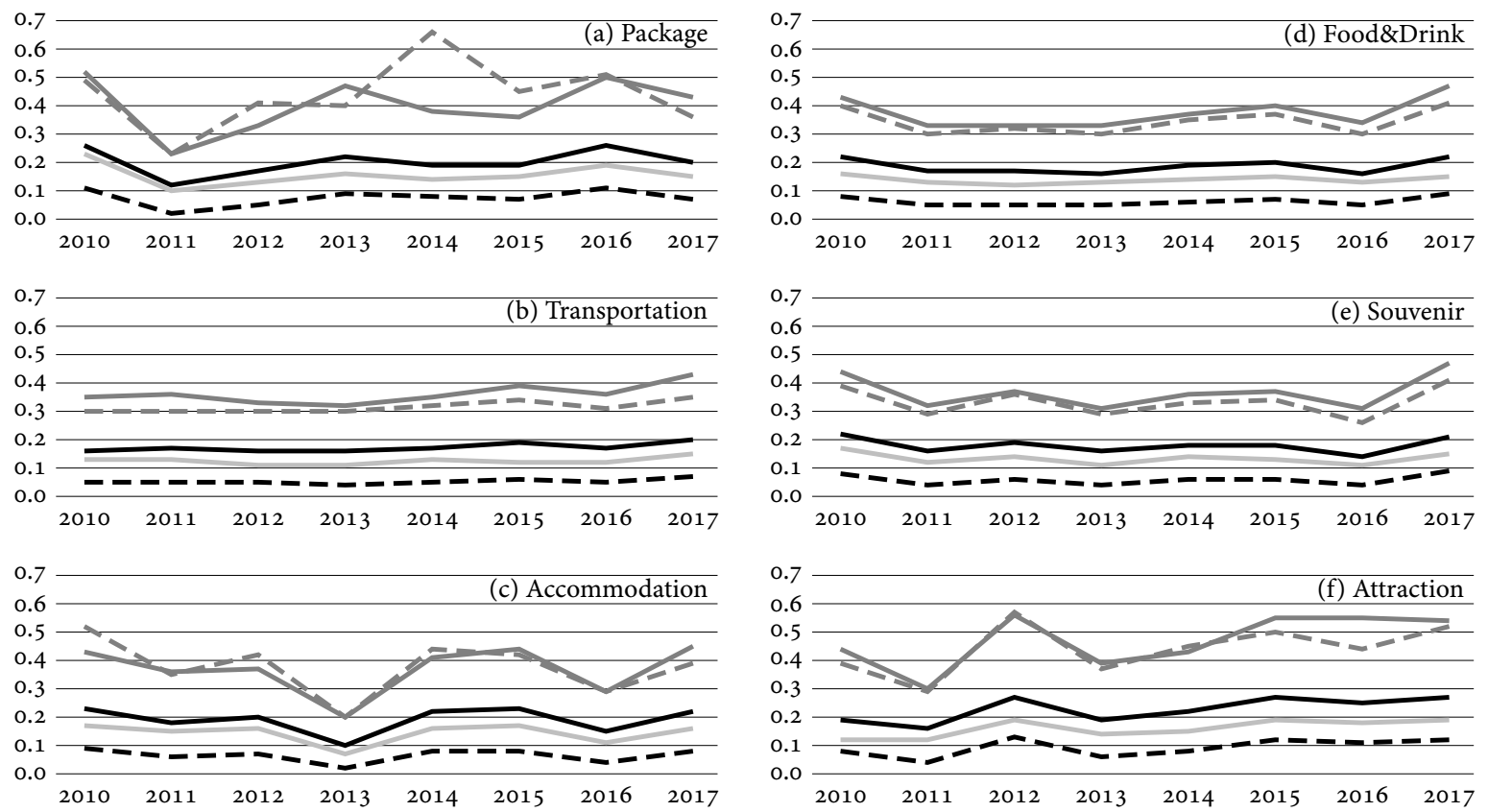

Figure 2 Seasonality Fluctuation for vFR Travel

Notes Light gray - relative mean deviation, dark gray - coefficient of variation, dark gray dashed - standard deviation of logs, black - Gini coefficient, black dashed - Theil entropy measure.

decrease in 2011 and a gradual increase after that with a large increase in 2017. The results are large fluctuations in seasonality over the observation period. Figure $3(\mathrm{f})$ shows fluctuations for attraction with drops in 2011, followed by inverted U shapes with peaks in 2013 and ending in 2016 with large increases in 2017 for most indicators. This indicates large fluctuations in seasonality over the observation period.

\section{Changes to Seasonality over the Observation Period for Each Consumption Item of Each Travel Purpose}

Next, the changes in the seasonality between the first and last fiscal year of the observation period will be compared for holiday travel, v F R travel, and business travel to observe whether the seasonality is increasing or decreasing over the years. From Table 1, business travel shows that for all consumption items, all the indicators are increasing. This suggests that business travel has not been able to reduce the seasonality during the observation period, compared to holiday and VFR travel. For VFR travel, the indicators have increased in four out of the six consumption items: transportation, foodedrink, souvenir, and attraction. However, the monthly seasonality for package and accommodation have decreased. Concerning holiday travel, the indicators for half of the consumption items, package, souvenir, and attraction have increased, while they have decreased for transportation, accommodation, and fooderdrink.

Since the results for the different indicators (relative mean deviation, coefficient of variation, the standard deviation of logs, Gini coefficient and Theil entropy measure) on seasonality show consistently similar trends, the remaining analysis will focus on the Gini coefficient, which is frequently used to examine seasonality.

The Magnitude of the Seasonality for Each Consumption Item by Travel Purpose over the Observation Period

Next, the magnitude of the seasonality over the observation period will be examined for each consumption 

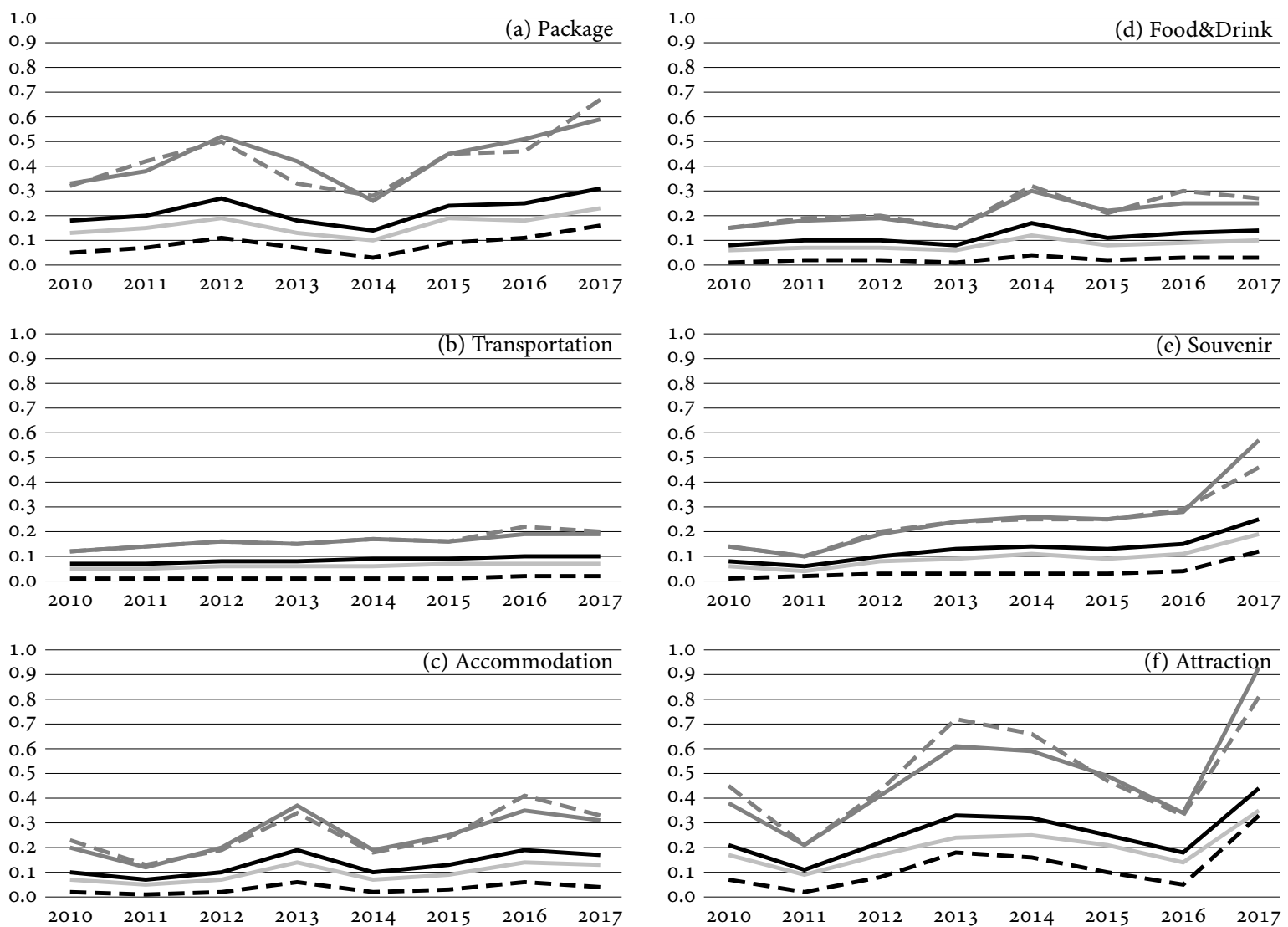

Figure 3 Seasonality Fluctuations for Business Travel

Notes Light gray - relative mean deviation, dark gray - coefficient of variation, dark gray dashed - standard deviation of logs, black - Gini coefficient, black dashed - Theil entropy measure.

item by travel purpose. The mean of the Gini coefficient for the observation period will be used to determine the magnitude of the seasonality.

From Figure 4(a) and Table 2, concerning holiday travel, the seasonality for accommodation is the largest amongst the six consumption items during the observed period. This is followed by the seasonality for transportation and foodedrink. Attraction is next in most years with souvenir and package showing the smallest seasonality. The seasonality for package is not only low but is stable for the more recent years. This suggests that travel agencies have been able to reduce seasonality differences with effective group travel or package tours throughout the year.

Next, from Table 2, as for VFR travel, the season- ality for attraction is larger than others during the observed period. In particular, as seen in Figure 4(b), seasonality has been great in recent years. Table 2 shows that package has the second largest seasonality out of the six consumption items with substantial changes by year. This is followed by accommodation and foodedrink. Figure 4(b) shows that accommodation has large fluctuation in seasonality depending on the year. In contrast, Figure 4 (b) shows that foodઐdrink seasonality is stable throughout the observed years, maintaining the middle position over the observation period. Souvenir achieves a lower level of seasonality in the more recent years, achieving one of the lowest positions. Transportation maintains a low position throughout the observation period with min- 
Table 1 Comparison of Seasonality between the First Year of Observation and the Last Year of Observation

\begin{tabular}{|c|c|c|c|}
\hline Item & Holiday & VFR & Business \\
\hline Package & Increase in all indicators & Decrease in all indicators & Increase in all indicators \\
\hline Transportation & $\begin{array}{l}\text { Moderate decrease in all indi- } \\
\text { cators }\end{array}$ & Increase in all indicators & Increase in all indicators \\
\hline Accommodation & $\begin{array}{l}\text { Moderate decrease in majority } \\
\text { of indicators }\end{array}$ & $\begin{array}{l}\text { Moderate decrease in majority } \\
\text { of indicators and decrease for } \\
\text { remaining }\end{array}$ & Increase in all indicators \\
\hline Food\&Drink & $\begin{array}{l}\text { Moderate decrease in all indi- } \\
\text { cators }\end{array}$ & $\begin{array}{l}\text { Moderate increase in more } \\
\text { than half of indicators }\end{array}$ & Increase in all indicators \\
\hline Souvenir & Increase in all indicators & $\begin{array}{l}\text { Moderate increase in more } \\
\text { than half of indicators }\end{array}$ & Increase in all indicators \\
\hline Attraction & Increase in all indicators & Increase in all indicators & Increase in all indicators \\
\hline
\end{tabular}
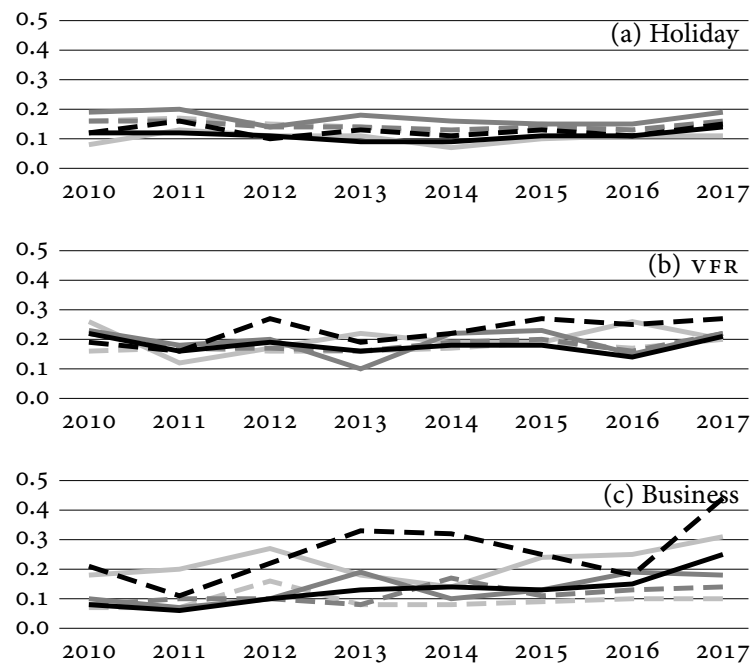

Figure 4 Fluctuation by Consumption Item: Gini

Notes Light gray - package, light gray dashed - transportation, gray - accommodation, gray dashed - food\&drink, black - souvenir, black dashed - attraction.

imum fluctuation over the years, which suggests the least impact of seasonality.

With respect to business travel, Table 2 shows that attraction has the most substantial fluctuation in seasonality out of the six consumption items for the period observed. Figure 4(c) confirms that it is also the largest in most years. This is followed by package and
Table 2 Mean of Gini Coefficient from 2010 to 2017

\begin{tabular}{|c|c|c|c|}
\hline Item & Holiday & VFR & Business \\
\hline Package & $0.104(6)$ & $0.202(2)$ & $0.220(2)$ \\
\hline Transportation & $0.145(2)$ & $0.172(6)$ & $0.085(6)$ \\
\hline Accommodation & $0.170 \quad(1)$ & $0.192 （ 3)$ & $0.130 （ 3)$ \\
\hline Food\&Drink & $0.143(3)$ & $0.187(4)$ & $0.112 （ 5)$ \\
\hline Souvenir & $0.112 （ 5)$ & $0.180 \quad(5)$ & 0.128 \\
\hline Attraction & $0.127(4)$ & 0.228 (1) & $0.257(1)$ \\
\hline Mean & $0.134 （ 3)$ & $0.194(1)$ & $0.156(2)$ \\
\hline
\end{tabular}

Notes Numbers in parentheses represent the rank order.

then accommodation and souvenir. Figure 4(c) shows that the fluctuation in seasonality for accommodation is not consistent over the years. The seasonality for food $\checkmark d r i n k$ is stable for the most recent fiscal years at a consistently low level. Transportation has the least fluctuation over the years, mostly at the lowest level. This is similar to the results of VFR travel.

\section{Comparing the Magnitude of the Seasonality between Travel Purposes}

Table 2 shows that the seasonality of holiday travel is the smallest of the three travel purposes with a value of o.134. Business travel is second with 0.156. VFR travel is third with 0.194 , suggesting that it is the most unstable. 

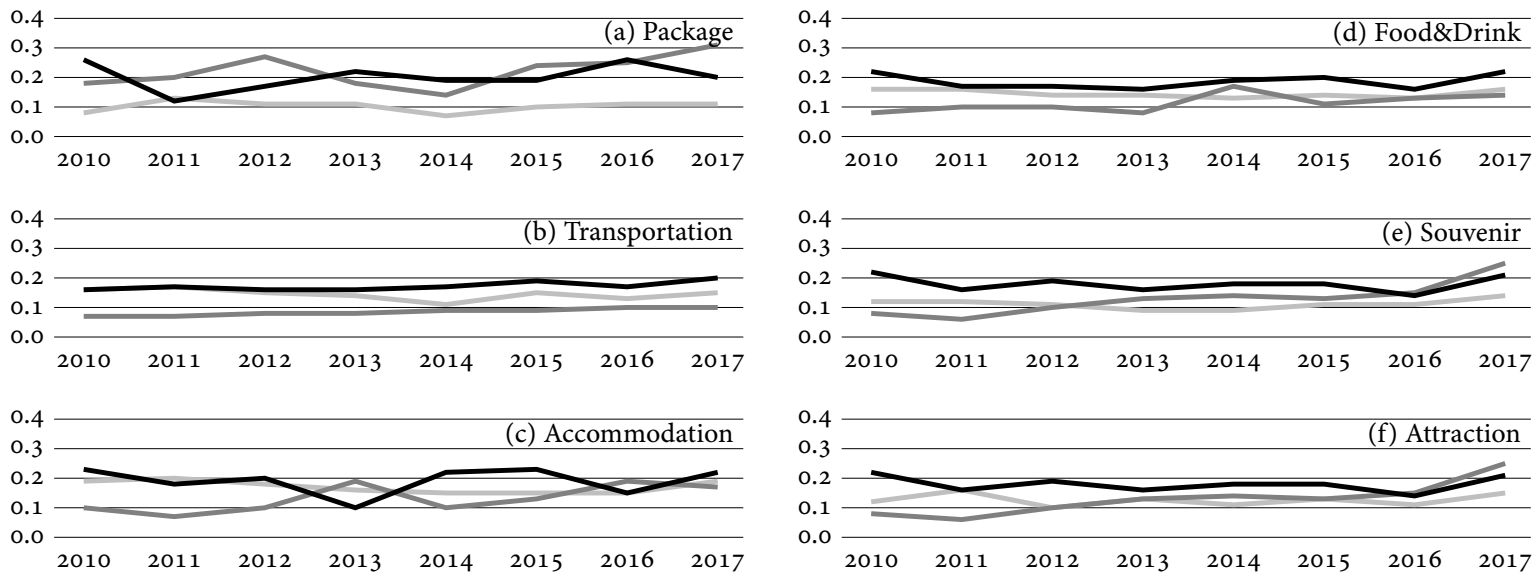

Figure 5 Seasonality Trends by Consumption Item

Notes Light gray - holiday, dark gray - business, black - vF R.

\section{Comparing Seasonality Trends between Travel Purposes for Each Consumption Item}

Next, for each consumption item, we compare the annual seasonality trends for each travel purpose. Concerning package, Figure 5(a) shows that holiday travel has the lowest seasonality difference during most of the period observed. There is also an indication that the fluctuations across the fiscal years are limited for holiday travel.

In contrast, the difference in seasonality is high for business and VFR travel, and the fluctuations across the fiscal years are large for both. Hence, depending on the year, business travel or VFR travel may have the largest seasonality.

Next, concerning transportation, Figure 5(b) indicates that business travel consistently has the least seasonality impact out of the three travel purposes for the period observed. It also shows that the fluctuations across the fiscal years for business travel are limited. Holiday travel appears second concerning the level of seasonality. Seasonality for VFR travel is the greatest for most of the period observed and is consistently high over the years.

With respect to accommodation, Figure 5(c) shows that holiday travel is mostly in second place concerning seasonality for most of the years, and the seasonality is stable across the period observed. Business travel and VFR travel show large changes in the order of sea- sonality. Business travel often shows the lowest seasonality, but it appears as the highest twice, showing large fluctuations depending on the year. VFR travel often shows the largest seasonality, but it appears as the lowest twice, which represents large changes in seasonality.

With regard to foodઐdrink, Figure 5(d) shows that the seasonality of VFR travel is consistently larger than the others during the observation period and the seasonality of business travel is smaller than the others for most of the period. The seasonality for holiday travel is the second largest and stable over the years observed.

As for souvenir, Figure 5(e) indicates that the seasonality of holiday travel is smaller than others for most of the period observed, and the fluctuations across the fiscal years are small. The seasonality of business travel starts at the lowest level of the three travel purposes, but shows an increasing trend, ending with the highest level of seasonality. Excluding the last two years, VFR travel shows the greatest seasonality over the years.

Concerning attraction, Figure 5 (f) shows that the seasonality for business travel tends to increase. The seasonality of VFR travel is larger than others for most of the period observed. The seasonality of holiday travel is relatively small and alternates between an increase and decrease every year, 
Table 3 Spearman's Rank Correlation Test: Mean of Gini Coefficient

\begin{tabular}{lrrr}
\hline Item & $\begin{array}{r}\text { Holiday vs } \\
\text { VFR }\end{array}$ & $\begin{array}{r}\text { Holiday vs } \\
\text { Business }\end{array}$ & $\begin{array}{r}\text { VFR vs } \\
\text { Business }\end{array}$ \\
\hline Spearman's rho & -0.3143 & -0.4286 & 0.9429 \\
Pro. $>|t|$ & 0.5441 & 0.3965 & 0.0048 \\
$N$ & 6 & 6 & 6 \\
\hline
\end{tabular}

Seasonality Characteristics for Each Consumption Item by Travel Purpose

Next, the similarities between seasonality for the different travel purposes for each consumption item and their characteristics will be observed. Table 2 shows that the seasonality for souvenir is relatively small and stable compared to the other consumption items for each of the travel purposes. In contrast, Table 3 shows that the seasonality for accommodation is substantial in all of the travel purposes.

According to Spearman's rank correlation coefficient of Table 3, the rank for the seasonality of the consumption items for business travel and that of VF R travel are significantly positively correlated, suggesting that they are similar. For instance, in Table 2, the seasonality for attraction and package for both business and VF R travel are significant and, thus, unstable. In contrast, the seasonality for transportation for both business and VFR travel are smaller and more stable than the others. Moreover, Table 3 shows that the ranking between the seasonality for consumption items of holiday travel and VFR/business travel are negatively correlated, suggesting that they have opposite results. However, it should be noted that the correlation is not significant.

\section{The Fluctuation of the Seasonality for Each} Consumption Item for Each Travel Purpose over the Observation Period

Next, in order to observe the fluctuation of the seasonality during the observation period, the standard deviation of the Gini coefficient will be measured for each consumption item. ${ }^{1}$ The aim is to examine whether

${ }^{1}$ Due to limitation of space, the results on the fluctuation of the seasonal range have been omitted due to similar results
Table 4 Standard Deviation of Gini Coefficient between 2010 and 2017

\begin{tabular}{lllll}
\hline Item & \multicolumn{1}{l}{ Holiday } & \multicolumn{2}{c}{ VFR } & \multicolumn{2}{c}{ Business } \\
\hline Package & $0.018(3)$ & $0.046(1)$ & $0.056(3)$ \\
Transportation & $0.018(4)$ & $0.014(6)$ & $0.012(6)$ \\
Accommodation & $0.019(2)$ & $0.045(2)$ & $0.047(4)$ \\
Food\&Drink & $0.013(6)$ & $0.025(5)$ & $0.030 \quad(5)$ \\
Souvenir & $0.016(5)$ & $0.025(4)$ & $0.059(2)$ \\
Attraction & $0.020(1)$ & $0.043(3)$ & $0.102(1)$ \\
Mean & $0.017(3)$ & $0.033(2)$ & $0.051(1)$ \\
\hline
\end{tabular}

Notes Numbers in parentheses represent the rank order.

the year-to-year fluctuations of the seasonality of consumption items for each fiscal year are large. The confirmation of such trends will aid in understanding the stability and predictability of the market.

First of all, Table 4 indicates that, concerning holiday travel, the order of fluctuation over the fiscal years concerning the seasonality of the expenditure, starting from the largest, is attraction, accommodation, package, transportation, souvenir, and foods drink. With respect to holiday travel, the fluctuations of the seasonality for foodsdrink (0.013) and souvenir (o.016) are particularly small, and attraction (0.020) and accommodation (0.019) are relatively large for holiday travel. The mean of the fluctuations of the seasonality of all consumption items for holiday travel is smaller than those of the other travel purposes and is the most stable.

Next, concerning business travel, Table 4 shows that the order of seasonality fluctuation amongst the fiscal years, starting from the largest, is attraction, souvenir, package, accommodation, foodઐdrink, and transportation. In particular, attraction (0.102), souvenir (0.059), and package (0.056) are large. Compared to the seasonality fluctuations for all consumption items for holiday and VFR travel, business travel shows a relatively large fluctuation for all consumption items, excluding transportation. The fluctuation for attraction, souvenir, and package are especially large, which means there are opportunities to address the

obtained from the standard deviation. Results can be provided upon request. 
seasonality in business travel for these areas. Finally, concerning VFR travel, Table 4 indicates that the seasonality fluctuation amongst the fiscal years, in order of size, is package, accommodation, attraction, souvenir, foodઐdrink, and transportation. In order to reduce the seasonality in VFR travel, consumption items with the largest fluctuation, such as package (o.046) and accommodation (0.045), will need to be prioritised.

The Seasonality Fluctuation for Total Travel

Expenditure by Travel Purpose

across the Observation Period

From Table 4, the fluctuation amongst the fiscal years concerning seasonality of the total travel expenditure for holiday travel shows the lowest level of fluctuation and that it is the most stable over the observation period with a value of 0.017 . The second is VFR travel with a value of 0.033 . The third is business travel with a value of 0.051 , suggesting that it is the most unpredictable of the three travel purposes. Hence, business travel is where there are the most significant opportunities to reduce the seasonality fluctuations and develop a more stable market.

Characteristics of the Seasonality Fluctuation for Each Consumption Item across the Observation Period for Each Travel Purpose

Next, concerning the fluctuation of seasonality across the fiscal years for each consumption item by travel purpose will be examined for similarities and characteristics. Table 4 shows that the seasonality fluctuations across the fiscal years for attraction and package are significant in each of the travel purposes. Therefore, these businesses could be considered unstable and challenging from a planning perspective. In contrast, Table 4 shows that the seasonality fluctuation across the fiscal years for each travel purpose is small for transportation and food/drink. Therefore, these can be considered to be stable in each of the travel purposes. According to Spearman's rank correlation coefficient in Table 5, the rank between the seasonality of the consumption items for holiday travel and that of VF R travel; between that of holiday travel and that of business travel; and between that of VFR travel and
Table 5 Spearman's Rank Correlation Test: Standard Deviation of Gini Coefficient

\begin{tabular}{lrrr}
\hline Item & $\begin{array}{r}\text { Holiday vs } \\
\text { VFR }\end{array}$ & $\begin{array}{r}\text { Holiday vs } \\
\text { Business }\end{array}$ & $\begin{array}{r}\text { VFR vs } \\
\text { Business }\end{array}$ \\
\hline Spearman's rho & 0.6 & 0.4857 & 0.5429 \\
Pro. $>|t|$ & 0.208 & 0.3287 & 0.2657 \\
$N$ & 6 & 6 & 6 \\
\hline
\end{tabular}

that of business travel, are all positively correlated, suggesting that they are similar. However, it should be noted that these correlations are not significant.

Highest and Lowest Expenditure Months for Each Consumption Item by Travel Purpose

Next, the months with the highest and lowest expenditure for each consumption item by travel purpose will be examined. The primary purpose is to understand the months when expenditure is concentrated and when it is light for each consumption item and travel purpose.

Concerning holiday travel, Table 6 shows that August has the most significant expenditure for all the fiscal years observed for all consumption items excluding package. It can be assumed that this is due to August being the month when most workers in Japan take their summer holidays as well as children and students being out of school for summer. Though August does appear to have the largest expenditure for package in some years, others show October and November to have the largest expenditure. This is likely to do with autumn being a popular season to take holidays to enjoy the autumn foliage. Concerning the month with the smallest expenditure, Table 6 shows that February is the smallest month for the majority of the fiscal years observed, for all consumption items except for package. This may be due to February being one of the coldest months and the shortest one.

Next, concerning VF R travel, Table 7 indicates that August has the largest expenditure for transportation, foodsdrink, souvenir, and attraction for all of the fiscal years observed. Concerning accommodation, though August is the largest for most years, May, which has the Golden Week holiday, also appears as the largest in some years. Concerning the month with the smallest 
Table 6 Highest/Lowest Month: Holiday Travel

\begin{tabular}{|c|c|c|c|c|c|c|c|c|c|c|c|c|c|}
\hline \multirow[t]{2}{*}{ Year } & \multirow[t]{2}{*}{ Category } & \multicolumn{2}{|c|}{ Package } & \multicolumn{2}{|c|}{ Transportation } & \multicolumn{2}{|c|}{ Accommodation } & \multicolumn{2}{|c|}{ Food\&Drink } & \multicolumn{2}{|c|}{ Souvenir } & \multicolumn{2}{|c|}{ Attraction } \\
\hline & & Highest & Lowest & Highest & Lowest & Highest & Lowest & Highest & Lowest & Highest & Lowest & Highest & Lowest \\
\hline \multirow[t]{2}{*}{2010} & Month & Aug & Dec & Aug & Jan & Aug & Feb & Aug & Feb & Aug & Feb & Aug & Feb \\
\hline & AC & 259859 & 136560 & 378480 & 139755 & 267149 & 75877 & 182239 & 62890 & 227685 & 102993 & 113717 & 53790 \\
\hline \multirow[t]{2}{*}{2011} & Month & Nov & Jan & Aug & Feb & Aug & Apr & Aug & Mar & Aug & Jan & Aug & Feb \\
\hline & $\mathrm{AC}$ & 288206 & 131273 & 387680 & 141676 & 256961 & 61236 & 180941 & 69076 & 225305 & 114052 & 109787 & 41491 \\
\hline \multirow[t]{2}{*}{2012} & Month & Nov & Jan & Aug & Jan & Aug & Feb & Aug & Feb & Aug & Feb & Aug & Jan \\
\hline & $\mathrm{AC}$ & 257769 & 137887 & 382490 & 128591 & 270117 & 74050 & 172653 & 58856 & 219980 & 104617 & 105279 & 46177 \\
\hline \multirow[t]{2}{*}{2013} & Month & Nov & Jan & Aug & Feb & Aug & Jan & Aug & Feb & Aug & Feb & Aug & Apr \\
\hline & $\mathrm{AC}$ & 266378 & 136819 & 380309 & 144192 & 290260 & 97202 & 186826 & 73534 & 222944 & 111822 & 111254 & 52937 \\
\hline \multirow[t]{2}{*}{2014} & Month & Oct & Feb & Aug & Feb & Aug & Apr & Aug & Jun & Aug & Apr & Aug & Feb \\
\hline & AC & 212634 & 139701 & 453342 & 209616 & 245880 & 80528 & 181486 & 80833 & 220746 & 123243 & 101917 & 50574 \\
\hline \multirow[t]{2}{*}{2015} & Month & Nov & Jan & Aug & Jan & Aug & Jun & Aug & Feb & Aug & Feb & Aug & Feb \\
\hline & $\mathrm{AC}$ & 255862 & 142842 & 404871 & 158664 & 289070 & 95127 & 198797 & 82746 & 215031 & 109328 & 116608 & 51556 \\
\hline \multirow[t]{2}{*}{2016} & Month & Aug & $\mathrm{Feb}$ & Aug & Feb & Aug & Feb & Aug & Feb & Aug & Feb & Aug & Feb \\
\hline & AC & 253083 & 131237 & 403812 & 154507 & 293535 & 96196 & 189689 & 79821 & 215239 & 98960 & 108370 & 53189 \\
\hline \multirow[t]{2}{*}{2017} & Month & Oct & Jan & Aug & Feb & Aug & Feb & Aug & Feb & Aug & Jan & Aug & Jan \\
\hline & AC & 223251 & 91173 & 444908 & 157122 & 343839 & 88511 & 211194 & 75414 & 239616 & 92355 & 134485 & 51114 \\
\hline
\end{tabular}

Notes AC: the amount of consumption. Unit of AC: Million yen.

Table 7 Highest/Lowest Month: vfr Travel

\begin{tabular}{|c|c|c|c|c|c|c|c|c|c|c|c|c|c|}
\hline \multirow[t]{2}{*}{ Year } & \multirow[t]{2}{*}{ Category } & \multicolumn{2}{|c|}{ Package } & \multicolumn{2}{|c|}{ Transportation } & \multicolumn{2}{|c|}{ Accommodation } & \multicolumn{2}{|c|}{ Food\&Drink } & \multicolumn{2}{|c|}{ Souvenir } & \multicolumn{2}{|c|}{ Attraction } \\
\hline & & Highest & Lowest & Highest & Lowest & Highest & Lowest & Highest & Lowest & Highest & Lowest & Highest & Lowest \\
\hline \multirow[t]{2}{*}{2010} & Month & Jan & Sep & Aug & Feb & Aug & Feb & Aug & Feb & Aug & Feb & Aug & Jun \\
\hline & AC & 27837 & 7920 & 267710 & 87326 & 29814 & 4398 & 81327 & 20758 & 116172 & 30131 & 31257 & 6457 \\
\hline \multirow[t]{2}{*}{2011} & Month & Jul & Mar & Aug & Oct & May & Jan & Aug & Oct & Aug & Jun & Aug & Nov \\
\hline & AC & 18456 & 10349 & 284114 & 103719 & 31322 & 9438 & 65654 & 25699 & 103865 & 37237 & 19182 & 7648 \\
\hline \multirow[t]{2}{*}{2012} & Month & Aug & Dec & Aug & Feb & May & Feb & Aug & Feb & Aug & Feb & Aug & Feb \\
\hline & AC & 22401 & 4750 & 266385 & 82303 & 29800 & 8268 & 69559 & 19209 & 101836 & 26946 & 26454 & 2725 \\
\hline \multirow[t]{2}{*}{2013} & Month & Jan & Feb & Aug & Feb & Aug & Feb & Aug & Feb & Aug & Feb & Aug & Jul \\
\hline & $\mathrm{AC}$ & 28410 & 6506 & 266396 & 79140 & 26120 & 12766 & 75068 & 26164 & 93767 & 31094 & 22067 & 5622 \\
\hline \multirow[t]{2}{*}{2014} & Month & Dec & Apr & Aug & Feb & Aug & Apr & Aug & Feb & Aug & Apr & Aug & Feb \\
\hline & AC & 11989 & 1354 & 252633 & 79910 & 29724 & 6991 & 62438 & 18197 & 91645 & 29009 & 20047 & 3741 \\
\hline \multirow[t]{2}{*}{2015} & Month & Dec & Feb & Aug & Feb & Aug & Jun & Aug & Feb & Aug & Feb & Aug & Nov \\
\hline & AC & 20815 & 5448 & 293842 & 87252 & 46395 & 11309 & 83428 & 23798 & 99102 & 24525 & 22382 & 4067 \\
\hline \multirow[t]{2}{*}{2016} & Month & Oct & Mar & Aug & Feb & Aug & Jan & Aug & Feb & Aug & Feb & Aug & Jun \\
\hline & AC & 28660 & 4184 & 279914 & 85960 & 30406 & 11854 & 77845 & 27170 & 95495 & 39284 & 26666 & 5572 \\
\hline \multirow[t]{2}{*}{2017} & Month & Jan & Oct & Aug & Feb & Aug & Jul & Aug & Feb & Aug & Feb & Aug & Feb \\
\hline & AC & 23301 & 6385 & 339206 & 93179 & 46771 & 11305 & 106443 & 21976 & 129032 & 21349 & 25535 & 3322 \\
\hline
\end{tabular}

Notes AC: the amount of consumption. Unit of AC: Million yen.

expenditure for VFR travel, Table 7 indicates February is the most frequent for all the consumption items. In particular, the frequencies are high for transporta- tion, foodઐdrink, and souvenir. Package does not show a clear largest or smallest expenditure month.

Finally, concerning business travel, Table 8 shows 
Table 8 Highest/Lowest Month: Business Travel

\begin{tabular}{|c|c|c|c|c|c|c|c|c|c|c|c|c|c|}
\hline \multirow[t]{2}{*}{ Year } & \multirow[t]{2}{*}{ Category } & \multicolumn{2}{|c|}{ Package } & \multicolumn{2}{|c|}{ Transportation } & \multicolumn{2}{|c|}{ Accommodation } & \multicolumn{2}{|c|}{ Food\&Drink } & \multicolumn{2}{|c|}{ Souvenir } & \multicolumn{2}{|c|}{ Attraction } \\
\hline & & Highest & Lowest & Highest & Lowest & Highest & Lowest & Highest & Lowest & Highest & Lowest & Highest & Lowest \\
\hline \multirow[t]{2}{*}{2010} & Month & Feb & Nov & $\mathrm{Feb}$ & Aug & $\mathrm{Feb}$ & Aug & Feb & Oct & Feb & Dec & Feb & Nov \\
\hline & $\mathrm{AC}$ & 1881 & 666 & 9733 & 6605 & 3295 & 1558 & 7442 & 4412 & 6205 & 3932 & 1562 & 450 \\
\hline \multirow[t]{2}{*}{2011} & Month & Oct & Mar & Jun & Jan & Sep & Jan & Jun & Apr & Jul & Apr & Feb & Sep \\
\hline & $\mathrm{AC}$ & 1344 & 343 & 9155 & 5428 & 2696 & 1720 & 7044 & 3742 & 5617 & 4169 & 1114 & 591 \\
\hline \multirow[t]{2}{*}{2012} & Month & Jul & Jan & May & Jan & Jun & Jan & Feb & Jan & Jul & Jan & May & Dec \\
\hline & $\mathrm{AC}$ & 45289 & 8164 & 168714 & 96883 & 46058 & 22693 & 39065 & 18179 & 27119 & 13716 & 10026 & 2475 \\
\hline \multirow[t]{2}{*}{2013} & Month & Jul & Mar & Jun & Jan & Jan & Nov & Mar & Aug & Feb & Mar & Jun & Dec \\
\hline & $\mathrm{AC}$ & 57084 & 16594 & 171642 & 97825 & 60233 & 20711 & 37509 & 24568 & 29503 & 14463 & 11556 & 1328 \\
\hline \multirow[t]{2}{*}{2014} & Month & $\mathrm{Feb}$ & Dec & Mar & Aug & Mar & Aug & May & Aug & Feb & Apr & Oct & Jan \\
\hline & $\mathrm{AC}$ & 26426 & 10192 & 167316 & 96650 & 43908 & 24249 & 53300 & 18374 & 32462 & 14594 & 12394 & 2008 \\
\hline \multirow[t]{2}{*}{2015} & Month & Dec & Feb & Jun & Jan & Dec & Oct & Nov & Jan & Oct & Jan & Dec & Sep \\
\hline & $\mathrm{AC}$ & 48280 & 14039 & 171392 & 106743 & 51190 & 22503 & 47332 & 23597 & 28623 & 11593 & 8165 & 2402 \\
\hline \multirow[t]{2}{*}{2016} & Month & Nov & Apr & Jun & Jan & Jun & Jan & Jul & Jan & Nov & Mar & Sep & Oct \\
\hline & $\mathrm{AC}$ & 50219 & 10877 & 183015 & 95890 & 68123 & 15875 & 55358 & 16978 & 33335 & 13490 & 6414 & 2387 \\
\hline \multirow[t]{2}{*}{2017} & Month & May & Jan & Jun & Feb & Oct & Feb & Dec & Jan & Nov & Jan & Nov & Aug \\
\hline & AC & 54659 & 4606 & 177996 & 91970 & 56674 & 19927 & 49673 & 22559 & 62008 & 9766 & 22605 & 1975 \\
\hline
\end{tabular}

Notes AC: the amount of consumption. Unit of AC: Million yen.

that there is no clear largest or smallest month, except for transportation where June is the largest month and January the smallest.

\section{Discussions}

The main results regarding seasonality are summarised as follows.

- Based on total expenditure, holiday travel is found to be the least impacted by seasonality and is the most stable of all the travel purposes. This is followed by business travel. Results from VF R travel suggest that it is the most unstable of the travel purposes. However, past studies by FernándezMorales, Cisneros-Martinez, and McCabe (2016) on the United Kingdom (UK) and by FernándezMorales (2017) on Spain, which compare the seasonality of these three travel purposes, find that holiday travel has the strongest seasonality impact and business travel the weakest. These studies examine the number of tourists, whereas this paper examines travel-related expenditure, which may be the reason for the difference, or it could be the difference in market conditions compared to Japan. Japan has 40-50\% more public holidays than the UK and Spain do, and they are spread out throughout the year. This suggests that the state interventions in Japan to provide a public holiday every month and the encouragement of the usage of paid holidays have been effective in reducing seasonality and improve productivity in the travel business (Morikawa, 2008; Yagasaki, 2015). The high seasonality in VF R travel could be due to a social-cultural effect. During the Bon Festival in August, the Japanese often return to their home town.

- For each travel purpose, the seasonality for souvenir is relatively small and stable compared to the other consumption items. The tradition in Japan of giving 'omiyage' (travel gifts) to colleagues at work and neighbours may be working positively to limit seasonality in this instance. In contrast, the seasonality for accommodation is large and irregular. The seasonality for each consumption item for business and VFR travel are positively related, and thus, are similar. For 
example, while the seasonality of attraction and package are large and unstable, the seasonality for transportation is the smallest and most stable of the consumption items for both business and VFR travel. However, holiday travel and business/V F R travel are negatively correlated, but statistically insignificant concerning the order of the seasonality of the consumption items.

- The main results concerning the increase/decrease in seasonality for each consumption item for the period observed are as follows.

1. Concerning business travel, the seasonality for all the consumption items increased. For VF R travel, the seasonality for four consumption items (transportation, foodsdrink, souvenir, and attraction) increased. In contrast, those of package and accommodation decreased. Finally, concerning holiday travel, the seasonality for half of the consumption items (package, souvenir, and attraction) increased, and the other half (transportation, accommodation, and foodedrink) decreased.

2. For all travel purposes, the seasonality of souvenir and attraction increased for the period observed.

Next, the main results concerning the fluctuation of the seasonality over the fiscal years are as follows.

- Seasonality fluctuation for holiday travel was the smallest and the most stable, followed by vFR travel and then business travel, which was the greatest. All the consumption items within holiday travel show the smallest fluctuation in seasonality over the fiscal years compared with the other travel purposes. In particular, the seasonality fluctuation for food/drink and souvenir are small. These results are slightly different from the intra-year seasonality result for which VF R travel showed the greatest seasonality. The impact on seasonality over the observed period on business trips may be influenced by the economy, which may have a larger impact on seasonality. Kulendran and Wilson (2000) suggest that the impact of economic variables is essential to understanding business travel.
- Concerning business travel, the seasonality fluctuation for attraction, souvenir, and package are large, indicating substantial changes in the seasonality depending on the year.

- Attraction and package are substantial for each of the travel purposes in terms of seasonality fluctuations across the fiscal years. This indicates instability and unpredictability. In contrast, the seasonality fluctuations for transportation and food $\triangleleft d r i n k$ are small for each of the travel purposes across the fiscal years, which make them easier to plan.

- The seasonality fluctuation of all the consumption items between holiday travel and business travel; between holiday travel and VFR travel; and between VFR travel and business travel are all positively-correlated, but the results are insignificant.

Next, the main observations concerning the largest and the smallest expenditure months are provided below.

- Concerning holiday travel, August is the month when the expenditure is the largest and February is the smallest. From the details of each consumption item, transportation, accommodation, foodઐdrink, souvenir, and attraction, the largest expenditure month for the observation period is August. The spending on package is high not only in August but also during the autumn foliage season of October and November. The lowest spending on transportation, accommodation, foodઐdrink, souvenir, and attraction is in February for most of the years observed. The same trend is seen in VFR travel, except the concentrations in the highest and lowest months are not as severe. The highest month for transportation, foodedrink, souvenir, and attraction is again August during the observation period. It is also the highest month for accommodation in most of the years observed. February is again the lowest month for all the consumption items. The concentration in February is especially high for transportation, foodsdrink, and souvenir. These observations indicate that for holiday and VFR 
travel, the seasonality is stable over multiple years, which will enable the development of a targeted strategy. Finally, concerning business travel, the seasonality for the largest and smallest expenditure months are more dispersed than holiday and V R F travel are. In particular, the large months are dispersed. Since the high seasonality months are not consistent over the years, a more flexible plan may be required to tackle the business travel market.

- Next, we will identify the three consumption items for each travel purpose concerning low seasonality and fluctuation across the period observed with stable ${ }^{2}$ largest and smallest months. These are souvenir of holiday travel, transportation and foodedrink of VF R travel and transportation of business travel. Since these areas are stable and predictable within each travel purpose, they will not be as difficult to plan and manage. In contrast, the three consumption items across the travel purposes with relatively significant seasonality and fluctuation and inconsistent largest and smallest months over the years, are package and attraction of VFR and business travel and accommodation of business travel. The magnitude of the seasonality and the fluctuation across multiple years will be substantial for these areas and the peak and off-peak months will not be consistent, which suggests unpredictable businesses which will be more challenging to plan and maintain.

These results that identify the areas of strong seasonality suggest future research opportunities to examine the determining factors behind the strong seasonality. For example, why is the seasonality impact on souvenirs weak and why is it strong for accommodations, and why is the seasonality for the consumption items for business and VFR travel similar? Considering that the seasonality results obtained for the three travel purposes were not consistent with previous re-

${ }^{2}$ Definition for stable in this section is if the largest (smallest) consumption month is consistent in five of the eight years observed between 2010 to 2017 . For years or less will be considered unstable. search studying other countries, which examined the number of visitors as the measurement unit of seasonality, it would be interesting to examine whether the results differ if the number of visitors was applied as the unit. This would provide insight into whether the differences are influenced by the measurement unit or if they stem from the markets examined.

\section{Conclusions}

As Japan aims to become a large tourist nation, it focuses on inbound policies and reinforcing domestic tourism by Japan residents. The travel industry is required to reduce the seasonality in the travel business in order to develop a more stable business with reliable income and to provide more stable employment. This paper aims to provide insight into the seasonality for each travel purpose. It analyses Japan holiday travel, VFR travel and business travel for each travel-related expenditure by consumption item using data for the fiscal years from 2010 to 2017 on domestic travel by Japan residents to observe the trends in seasonality.

These results that identify the consumption items that have predictable and stable seasonality as well as those that are difficult to predict and show an increasing seasonality trend provide several policy implications. The observation of the different travel purposes could assist in the development of strategies in differential pricing, diversified attraction, market diversification and facilitation by the state to address seasonality. Since the analysis is based on the expenditure of the various travel-related consumption items rather than the number of visitors, it provides insight to the areas that differential pricing may be effective and may assist in decisions concerning areas of the business to close during the off-season to reduce operational costs. Based on this analysis, the areas identified with seasonality challenges include package and attraction of VFR travel. This suggests opportunities for differential pricing of package holiday/tours expenses and entrance/attraction expenses aimed at families during the VFR travel off-peak seasons. Concerning the diversification of attraction, the timing or attracting the hosting of sport events and festivals could be considered based on the seasonality of the attraction expenditure. For example, during the off-peak of VFR 
travel, attractions and events aimed at families could be considered. Since package and attraction for business travel were also identified as a seasonality challenge for Japan, the timing of conferences and exhibitions during the off-peak seasons for business travel may be an effective solution. Promotion to encourage corporate incentives and meetings during this time and the development of packages could be considered. The analysis based on travel purposes and a range of travel expenditure may also facilitate the diversification of niche products and services. For example, in order to help address the business travel $a c$ commodation seasonality, the inclusivity of breakfast buffets, which is the 2 nd reason for the choice of accommodation (Development Bank of Japan \& Japan Economic Research Institute Inc., 2017), could be developed as a niche product aimed for business travel. The results of this paper also assist in identifying areas for market diversification. The observation of the seasonality for package holidays/tours, for instance, suggests an opportunity for tour operators and travel agents to develop new products and services for the VFR travel off-peak period, such as family-targeted packages. Considering that accommodation of business travel was also identified as an area with seasonality challenges, there is an opportunity for lodging and transportation businesses to cooperate and encourage business trips during the off-peak season for business travel. ${ }^{3}$ This analysis could also help target areas for state intervention. The seasonality challenge with VFR travel identified in this analysis may be addressed with the encouragement of companies providing more flexibility to enable paid holidays to be taken during the children's school breaks ${ }^{4}$ or the staggering of public holidays by region. The identification of consumption items and travel purposes with similar seasonality trends could also assist the local government in the development of relevant local business partnerships as well as in targeting necessary financial provisions such as loans and subsidies.

Granular analysis to support the segmentation of

\footnotetext{
${ }^{3}$ J т в has introduced such packages.

${ }^{4}$ In 2010, the Japan Tourism Agency set up the 'Family Time Development Project' to support this.
}

the tourism market is now easier to utilise with the development of the internet and social media. Local businesses and destinations can target and promote to an international niche audience. Information technology also supports the monitoring of performance and assists in planning differential pricing. With such possibilities in mind, this paper aims to support the appropriate development of policies that encourage the dispersity of tourism seasonality and support the sustainable development of tourism.

\section{References}

Allcock, J. B. (1989). Seasonality. In S. F. Witt \& L. Moutinho (Eds.), Tourism marketing and management handbook (pp. 387-392). Englewood Cliffs, NJ: Prentice-Hall.

Ball, R. M. (1988). Seasonality: A Problem for workers in the tourism labour market. Service Industries Journal, 8(4), 501-513.

Bar-On, R. R. (1975). Seasonality in tourism: A guide to the analysis of seasonality and trends for policy making (Technical Series No. 2). London, England: The Economist Intelligence Unit.

Baum, T., \& Hagen, L. (1999). Responses to seasonality: The experiences of peripheral destinations. International Journal of Tourism Research, 1(5), 299-312.

Butler, R. W. (1994). Seasonality in tourism: Issues and problems. In A. V. Seaton (Ed.), Tourism: The state of the art (pp. 332-339). Chichester, England: Wiley.

Butler, R. W. (2001). Seasonality in tourism: Issues and implications. In T. Baum \& S. Lundtorp (Eds.), Seasonality in tourism (pp. 5-22). Oxford, England: Pergamon.

Butler, R. W., \& Mao, B. (1997). Seasonality in tourism: Problems and measurement. In P. Murphy (Ed.), Quality management in urban tourism (pp. 9-23). Chichester, England: Wiley.

Commons, J., \& Page, S. J. (2001). Managing seasonality in peripheral tourism regions. In T. Baum \& S. Lundtorp (Eds.) Seasonality in tourism (pp. 153-172). Oxford, England: Pergamon.

Coshall, J., Charlesworth, R., \& Page, S. J. (2015). Seasonality of overseas tourism demand in Scotland: A regional analysis. Regional Studies, 49(10), 1603-1620.

De Cantis, S., Ferrante, M., \& Vaccina, F. (2011). Seasonal pattern and amplitude: A logical framework to analyse seasonality in tourism: An application to bed occupancy in sicilian hotels. Tourism Economics, 17(3), 655-675.

Development Bank of Japan \& Japan Economic Research Institute Inc. (2017). Shucho marketingni kansuru dokoto kongo shucho ryokono tourism gyokai niokeru impact. 
Retrieved from https://www.dbj.jp/ja/topics/region/ industry/files/ooooo29022_file2.pdf

Duro, J. A. (2016). Seasonality of hotel demand in the main Spanish provinces: Measurements and decomposition exercises. Tourism Management, 51, 52-63.

Duro, J. A. (2018). Seasonality of tourism: A new decomposition. Tourism Economics, 24(5), 615-621.

Faulkner, B., \& Tideswell, C. (1997). A framework for monitoring community impacts of tourism. Journal of Sustainable Tourism, 5(1), 3-28.

Fernández-Morales, A. (2017). Tourism mobility in time and seasonality in tourism. Rivista Italiana di Economia Demograia e Statisitca, 71(2), 35-52.

Fernández-Morales, A., Cisneros-Martinez, J. D., \& McCabe, S. (2016). Seasonal concentration of tourism demand: Decomposition analysis and marketing implications. Tourism Management, 56, 172-19o.

Fernández-Morales, A., \& Mayorga-Toledano, M. C. (2008). Seasonal concentration of the hotel demand in Costa del Sol: A decomposition by nationalities. Tourism Management, 29(5), 940-949.

Getz, D., \& Nilsson, P. A. (2004). Responses of family businesses to extreme seasonality in demand. Tourism Management, 25(1), 17-30.

Go, R. (1990). Resorts resurgent: Shoulder and off-season expand their base. Canadian Hotel and Restaurant, 68(8), 43-44.

Goulding, P. J., Baum, T. G., \& Morrison, A. J. (2004). Seasonal trading and lifestyle motivation: Experiences of small tourism businesses in Scotland. Journal of Quality Assurance in Hospitality \& Tourism, 5(2/3/4), 209-238.

Gustafson, P. (2002). Tourism and seasonal retirement migration. Annals of Tourism Research, 29(4): 899-918.

Hartmann, R. (1986). Tourism, seasonality and social change. Leisure Studies, 5(1), 25-33.

Higham, J., \& Hinch, T. D. (2002). Tourism, sport and seasons: The challenges and potential of overcoming seasonality in the sport and tourism sectors. Tourism Management, 23(2), 175-185.

Hinch, T. D., \& Hickey, G. P. (1997). Tourism attractions and seasonality: Spatial relationships in Alberta. In K. McKay (Ed.), Proceedings of the Travel and Tourism Research Association, Canadian Chapter (pp. 69-76). Winnipeg, Canada: University of Manitoba.

Hinch, T., \& Jackson, E. (200o). Leisure constraints research: Its value as a framework for understanding tourism seasonality. Current Issues in Tourism, 3(2), 87-106.

Jang, S. S. (2004). Mitigating tourism seasonality. Annals of Tourism Research, 31(4), 819-836.
Jeffrey, D., \& Barden, R. R. D. (1999). An analysis of the nature causes and marketing implications of seasonality in the occupancy performance of English hotels. Tourism Economics, 5(1), 69-91.

Jeffrey, D., Barden, R. R. D., Buckley, P. J., \& Hubbard, N. J. (2002). What makes for a successful hotel? Insights on hotel management following 15 years of hotel occupancy analysis in England. Service Industries Journal, 22(2), 7388.

Jolliffe, L., \& Farnsworth, R. (2003). Seasonality in tourism employment: Human resource challenges. International Journal of Contemporary Hospitality Management, 15(6), 312-316.

Juganaru, M., Aivaz, K. A., \& Juganaru, I. D. (2017). A comparative analysis regarding the seasonality of the number of monthly overnight stays in Romania and the European Union in 2005-2016. Transformations in Business and Economics, 24(2 A), 513-531.

Karamustafa, K., \& Ulama, S. (2010) Measuring the seasonality in tourism with the comparison of different methods. EuroMed Journal of Business, 5(2), 191-214.

Kennedy, E., \& Deegan, J. (2001). Seasonality in Irish tourism 1973-1995. In T. Baum \& S. Lundtorp (Eds.), Seasonality in tourism (pp. 51-74). Oxford, England: Pergamon.

Koc, E., \& Altinay, G. (2007). An analysis of seasonality in monthly per person tourist spending in Turkish inbound tourism from a market segmentation perspective. Tourism Management, 28(1), 227-237.

Krakover, S. (2000). Partitioning seasonal employment in the hospitality industry. Tourism Management, 21(5), 461-471.

Kulendran, N., \& Wilson, K. (2000). Modelling business travel. Tourism Economics, 6(1), 47-59.

Lee, C., Bergin-Seers, S., Galloway, G., O’Mahony, B., \& McMurray, A. (2008). Seasonality in the tourism industry: Impacts and strategies. Brisbane, Australia: CRC for Sustainable Tourism.

Lockwood, A., \& Guerrier, Y. (1990). Labour shortages in the international hotel industry. Travel and Tourism Analyst, $6,17-35$.

Lundtorp, S. (2001). Measuring tourism seasonality. In T. Baum \& S. Lundtorp (Eds.), Seasonality in tourism (pp. 23-50). Oxford, England: Pergamon.

Lundtorp, S., Rassing, C. R., \& Wanhill, S. R. C. (1999). The off-season is 'no season:' The case of the Danish island of Bornholm. Tourism Economics, 5(1): 49-68.

Manning, R. E., \& Powers, L. A. (1984). Peak and off-peak use: Redistributing the outdoor recreation/tourism load. Journal of Travel Research, 23(2), 25-31. 
Mathieson, A., \& Wall, G. (1982). Tourism: Economic, physical and social impacts. Essex, England: Longmann.

Morikawa, M. (2008). Service gyo niokeru jyuyo-hendo to seisansei (RIET I Discussion Paper Series, o8-j-042). Tokyo, Japan: Research Institute of Economy, Trade and Industry.

Murphy, P. E. (1981). Community attitudes to tourism: A comparative analysis. International Journal of Tourism Management, 3(2), 189-195.

Nadal, J. R., Riera-Font, A., \& Rossello, A. S. (2004). The economic determinants of seasonal patterns. Annals of Tourism Research, 31(3), 697-711.

Oi, T. (2013). S Shukuhaku-ryoko-tokei-chosa niyoru chiikikakusa no bunseki - Dagum no Gini keisu no yoinbunkai-bunseki wo mochiite. Kenkyu-shoho, 42, 29-48.

Oi, T. (2016). Kanko-chiiki niokeru kanko-jyuyo no kisetsuhendo no yoin-bunseki - Gini keisu oyobi yoin-bunkaishuho nimotozuku jisho-kenkyu. Nihon seisaku kinyuu kouko ronshu, 3, 39-59.

Sen, A. (1973). On economic inequality. Oxford, England: Clarendon Press.

Snepenger, D., Houser, B., \& Snepenger, M. (1990). Seasonality of demand. Annals of Tourism Research, 17(4), 628630.

Sutcliffe, C. M., \& Sinclair, M. T. (1980). The measurement of seasonality within the tourist industry: An application to tourist arrivals in Spain. Applied Economics, 12(4): 429441.
Šegota, T., \& Mihalič, T. (2018). Elicitation of tourist accommodation demand for counter-seasonal responses: Evidence from the Slovenian Coast. Journal of Destination Marketing \& Management, 9, 258-266.

Turrión-Prats, J., \& Duro, J. A. (2018). Tourist seasonality and the role of markets. Journal of Destination Marketing \& Management, 8, 23-31.

Williams, A. M., King, R., Warnes, A., \& Patterson, G. (2000). Tourism and international retirement migration: New forms of an old relationship in Southern Europe. Tourism Geographies, 2(1), 28-49.

Witt, S. F., \& Moutinho, L. (Eds.) (1995). Tourism marketing and management handbook. London, England: Prentice Hall.

Yagasaki, N. (2015). Kanko-jyuyo no hyojyunka nikansuru ichikosatsu: kyuka-seisaku no hensen ni syoten wo atete. Gendai-shakai-kenkyu, 13, 73-81.

This paper is published under the terms of the Attribution- NonCommercial-NoDerivatives 4.0 International (CC B Y-NC-ND 4.0) License. 


\title{
The Differences in Perceptions of Organisational Values in the Hospitality Sector: What Do They Tell Us?
}

\author{
Mitja Gorenak \\ University of Maribor, Faculty of Tourism, Slovenia \\ mitja.gorenak@um.si
}

Organisational values have been in the focus of management for several years. Knowing that strong values can help organisations stay on the right course in the fast-changing working environment has proven to be a solid basis for their prosperity. However, organisations are nothing without their employees; this led as to the question of what the differences in the perception of organisational values between employees of different ages and genders are. We have conducted research in the hospitality sector; based on a paper-pencil survey among a representative sample of 388 employees, we have determined that there are six predominant organisational values within the sector. In the second part, we have identified that two out of six identified organisational values are statistically significantly more highly evaluated in terms of importance by women in comparison to men. There were no statistically significant differences found regarding the age of employees.

Keywords: values, organisational values, hospitality, demographics, perception https://doi.org/10.26493/2335-4194.12.73-82

\section{Introduction}

In our rapidly changing world, the importance of understanding organisational values is becoming increasingly critical for every organisation. In the service sector, including hospitality, this is even more critical since this is a sector with steady economic growth (Prevolšek, Rozman, Pažek, Maksimović, \& Potočnik Topler, 2017; Rangus \& Brumen, 2016). The hospitality sector, known for its high turnover of employees (Brown, Bosselman, \& Thomas, 2016), due to the high-paced and very demanding working environment (Hsieh, Sönmez, Apostolopoulos, \& Lemke, 2017) that is continually changing with the arrival of new phenomena, such as the sharing economy (Turnšek \& Ladkin, 2017), will need to pay particular attention to its organisational values and how employees perceive them. Researchers (Hofstede, 1998; Rokeach, 1968) have been researching the field of val- ues, both on the individual and organisational levels, for decades. There is a rather common consensus that organisational values evolve from individual values (Collins \& Porras, 2005), while at first organisational values are very much related to the individual values of founding members of the organisation, later they are influenced by all the members of the organisation. Organisational values are an inseparable part of the organisational culture (Schein, 1985) and represent relatively (Rokeach, 1973) permanent, motivational, emotionally positive categories, for which people believe that they are worth aspiring to (love, peace, friendship, health, etc.). The answer to the question of why values are so important has been provided by Rokeach and Ball-Rokeach (1989), who have identified values as 'one of the very few social psychological concepts that have been successfully employed across all social science disciplines.' 
There is no question that organisational values serve many purposes. Hassan (2007) sees these purposes in the way the organisational values set the tone of the environment within the organisation, bind people together, facilitate work behaviour, and help achieve shared goals of the organisation. There is also a theory about managing by values (Dolan \& Garcia, 2002; Dolan, Garcia, \& Richley, 2006) that promotes the use of values and organisational values in management of the organisation with the concept of reducing formal control through trust gained through shared values. Some research (Dearlove \& Coomber, 1999) published before the work of Dolan, Garcia, and Richley indicates that value-led companies outperform others in both growth and revenue being up to four times faster, creation of new jobs up to seven times higher, growth in stock price up to twelve times higher and profit performance up to seven and a half times higher. Dearlove and Coomber (1999) also found that those same organisations experienced significantly lower employee turnover when they valued respect and teamwork. Kač, Gorenak, and Potočan (2016) determined that shared values influence trust within the organisation in a meaningful way. With the evidence that there is a significant influence of organisational values on company performance, we were interested in seeing how some general demographic differences influence the perception of organisational values and subsequently the performance of the individual within the organisation. For this reason, we have set ourselves the main research question; What are the differences in the perception of organisational values between (a) gender and (b) age group?

\section{Theoretical Background}

Values

Values are most commonly perceived as beliefs upon which individuals perform their tasks (Allport, 1961) in accordance with their personal preferences. Influenced by the upbringing the individual had, the society in which they grew up, and people with whom they have interacted values are relatively permanent (England, 1967). Unknown to the person, values present their perception frames that shape and influence the very core of individuals' behaviour. Rokeach (1968) sees this as representing an individual's attitudes towards how someone should or should not behave. In his opinion, values are types of beliefs that are centrally located in individuals' system of beliefs and influence individuals' behaviour (Rokeach, 1968). In the field of social psychology, extensive research has also been conducted regarding human values (Schwartz \& Bilsky, 1987), in which values are seen as beliefs or conceptualisations about desired end states or behaviours that exceed specific situations. In this sense, values direct the evaluation of behaviour based on the rate of relative importance to the individual.

The most commonly recognised classification divides values into two groups (Rokeach, 1973). The first group presents so-called instrumental values; these are values linked to the way people work. The second group are the so-called terminal values; these are related to the desired end state in contrast to the operational performance that is seen in instrumental values. Within each of the two basic types of values (instrumental and terminal), we find two sub-categories: the first sub-category of terminal values is personal terminal values; the second sub-category is social terminal values. This division is linked to the importance of a value, whether it is important to the individual (salvation, peace) or society (world peace, fraternity). In the set of instrumental values, we divide these into moral values and competence-based values. This division is linked to the individual's feelings, so moral values are linked to self-perception (sense of guilt), while competence values are linked to self-actualisation (logical reasoning). Both of them can come into conflict with themselves or between groups. Thus, an example of a conflict of two moral values is loving behaviour and sincere behaviour, an example of the conflict of two competence values is imaginative and logical thinking, and the example of the conflict between moral and competence values is polite behaviour and wellfounded criticism. Meglino and Ravlin (1998) have indicated that, from an organisational perspective, a greater focus on instrumental values as modes of behaviour is seen opposed to end-states of existence (terminal values).

Values are also changing due to changes in the environment; in many cases, we can see changes based 
on the changes in the economic sphere, as well as in the social and technical spheres (Freeman, Herriges, \& Kling, 2014). Values are also highly linked to generational differences, although as Parry and Urwin (2011) point out, the results of research focusing on differences in values based on generation are at best mixed: some studies show obvious differences, while others find none. We believe that, in this case, differences are more related to the intensity of the values than the values themselves.

Personal values are the basis upon which concepts of organisational values are presented, individuals are the founding blocks of any organisation, and without their personal values, there is no means of organisational values to evolve.

\section{Organisational Values}

Many authors (Ashforth \& Mael, 1989; Chatman \& Cha, 2003; Judge \& Cable, 1997; Kenny, 1994) have been exploring the field of organisational values in attempts to reach a consensus about the definition of such values. The most common view of organisational values is that they evolve from organisational culture; this is generally the philosophy that an organisation follows (Pfeiffer, Goodstein, \& Nolan, 1985). Kenny (1994) claims that just as any person or community has his/her/its set of values the same is true for every organisation. Given the fact that organisational culture defines expectations regarding behaviour, modes of conduct, modes of decision-making, and styles of communication, we can perceive organisational values through this (Simerly, 1987).

Organisational values emerge at the beginning of the existence of any organisation; although at the beginning they may seem a bit unclear, it can be said that they are very closely related to the personal values of the founding members of the organisation (Pfeiffer et al., 1985). It is not uncommon that further in the life of an organisation, members (usually management) decide to define organisational values. We have to understand that organisational values may be related to the founding members at first, but later, several things influence their evolution, such as dynamic of growth of the company, new employees, business success of the company, etc. Musek Lešnik (2008) explains the need for wide-ranging and open discussion about what the organisational values within the company really are so that they can be identified and that the 'trap' of management-defined organisational values be avoided. This was also emphasised by Cha and Edmondson (2006) warning about the potential hazards young organisations face, especially regarding organisational values: when an organisation is young and growing, ill-defined organisational values can hinder its growth and potentially endanger its development.

Organisational values and the long-term performance of organisations has been studied and established by many authors (Chatman \& Cha, 2003; Collins, 2001; Collins \& Porras, 2005; Peters, Waterman, \& Jones, 1982). More precisely, Collins and Porras (2005) have determined that organisations with clearly stated organisational values, which are internalised by employees, reach significantly higher performance results in comparison to organisations with values that are less clearly stated or not stated at all.

To understand the positive influence of organisational values on organisational performance, it is essential to understand how the fit of values is achieved. Five different theories predominate. The first is the socalled personality-environment fit theory that evolved from interactional theory (Lewin, 1951), in which the fit between personal values and environmental values is sought. The second is the theory seeking fit between person and job (personality-job fit theory) (Holland, 1985), while the third theory focuses on the fit between the person and the organisation (personalityorganisation fit theory) (Judge \& Cable, 1997); the remaining two theories are the theory that examines the fit between a person and his or her vocation (personality-vocational fit theory) (Hoerr, 1989) and the theory that examines the fit between a person and a group (personality-group fit theory) (Guzzo \& Salas, 1995).

The most critical finding in this sense came from Posner, Kouzes, and Schmidt (1985), who have empirically proven that the higher level of fit between organisational and personal values is clearly shown in individuals' positive approach to work as employees are more satisfied when they are performing their tasks.

However, the modern working environment is rais- 
ing yet another issue when it comes to organisational values: although we are creating working environments that are more and more flexible, and allow people to work from home or while travelling, we are creating work that is increasingly complex and requires greater cooperation, as indicated by Lee, Olson, and Trimi (2012). Globalisation itself, carried over from the 2oth century, along with new technological advantages, and changing demographics, is leading to changes in the industry, thus opening paths to new innovation paradigms that can help organisations create value through convergence, collaboration, and cocreation. However, as indicated by Ye (2012), organisational values can still be seen as the core of organisational culture, thus affecting a number of key or pivotal values concerning organisation-related behaviours and states-of-affairs, which are shared by members of an organisation. This is why organisational values define the acceptable that which govern the behaviour of individuals within the organisation.

Knowledge about values and specifically organisational values has led us to the question of how various demographical difference influence the perception of the importance of organisational values; this is presented in the next part of this article.

\section{Values, Organisational Values and Demographics}

The question about differences in perception of values between men and women as well as the question about differences between older and younger people has been a subject of discussion in the research community for quite some time. Prince-Gibson and Schwartz (1998) have determined that theories of gender-based value differences provide ambiguous results. Dietz, Kalof, and Stern (2002) have done extensive research on values, determining that there are no substantial differences in value factor structures, although they did find differences in value priorities, with women ranking altruism as more important than men did. Therefore, we can say that women value responsibility towards others as being more important than men do. This is vital knowledge with regards to hospitality, in which the well-being of others is at the core of every operation. Beutel and Marini (1995) have similar findings in their research, determining that females are more likely than males to express concern and responsibility for the well-being of others, less likely than males to accept materialism and competition, and more likely than males to indicate that finding purpose and meaning in life is extremely important.

This leads to the question of how individuals chose their occupation The link between individual values and organisational values is very well established (Kenny, 1994; Pfeiffer et al., 1985; Simerly, 1987); based on this, Marini, Fan, Finley, and Beutel (1996) have determined that individuals choose occupations on the basis of internalised interests and work values. Marini et al. (1996) have further determined that choosing an occupation involves finding the maximum highly valued occupational characteristics while minimising the loss of other enjoyable or necessary ones. This further strengthens the relationship between individual and organisational values.

Regarding organisational values, various studies have produced highly diverse results. Rudman and Phelan (2008) have determined that research on gender stereotypes generally shows that women are perceived to be more communal (e.g., caring and interdependent) than men are. Kite, Deaux, and Haines (2008) determined that women, for example, are viewed as more emotional, gentle, understanding, and devoted, whereas men are seen as more active, competitive, independent, and self-confident. Kwun (2011) claims that women tend to evaluate the importance of quality higher than men are. Interestingly, Jin, Line, and Goh (2013) have determined that while service quality is important for both males and females, the impact of aesthetics on relationship quality is only important for males.

In contrast, Posner (2010) says that are no differences that were found between men and women in his study, while previously significantly lower levels of values congruency had been reported by women. Parry and Urwin (2011) did extensive work on the question of generational differences and work values; their conclusion is that while many studies have found more areas of similarity between generations than differences, some that do find that differences have produced significant findings of only a small magnitude and have found differences in the opposite direction from that 
predicted by the commonly held generational stereotypes. Thus, it can only be concluded that some studies have found differences in work values between generations, while others have not.

\section{Methodology}

\section{Research Question and Hypothesis}

The research aimed to test how various groups of employees perceive the importance of organisational values in the hospitality sector. For that purpose, we have set the following research question: What are the differences in the perception of organisational values between (a) genders and (b) age groups?

In order to answer this research question, the following research hypotheses were set up:

$\mathrm{H} 1$ There is no statistically significant difference in the perception of organisational values between male and female employees.

$\mathrm{H} 2$ Older employees evaluate the importance of organisational values statistically significantly higher than younger employees do.

\section{Sample}

The population of the selected sector (travel and leisure industry) was based on the data of the Statistical Office of the Republic of Slovenia regarding a total of 9,117 people (see http://pxweb.stat.si). In order to obtain a relevant representation of this sample, we asked random organisations within the sector for permission to survey their employees; we were granted the consent of several organisations, which employ a total of 2,762 people. We distributed 1100 paper-pencil questioners among randomly selected employees; for this purpose, we used the simple random sampling method. Within the 6o-day period set for the survey, 388 out of 1100 questionnaires were returned, representing $35.27 \%$ of all questionnaires sent out, which is $4.26 \%$ of the population. The questionnaire comprised several parts, but only a part of the results are used for this study: 25 questions relating to organisational values and 5 questions regarding respondents' details (age, gender, number of working years, level of education, etc.).

To be able to generalise the results to the entire population, we first performed tests to establish the validity of the sample. For this step, we performed the chi-square test of significance on the demographic information for the population as well as the sample (gender, education, and age). For the variable gender, chi-square was calculated at 0.598 and significance level at $p=0.434 \mathrm{M}$ for the variable education, the chi-square test value was calculated at 9.296 with significance level at $p=0.054 \mathrm{M}$ the final variable age provided a value of 13.971, and the level of significance was at $p=0.052$.

The values of chi-square distribution at significance 0.05 or $5 \%$ are 3.8415 for variables with a single degree of freedom (variable gender), 9.4877 for variables with four degrees of freedom (variable education), and 14.0671 for variables with seven degrees of freedom (variable age). Based on these findings, we can conclude that the research sample could be generalised to the whole population (Hannan \& Freeman, 1977).

The sample that has been used for this paper contained $133(38.4 \%)$ male respondents and 213 (61.6\%) female respondents. The average age of respondents was calculated at 38.17 years. The sample contained 34 (9.6\%) respondents with elementary school level of education or less, $83(23.5 \%)$ respondents with vocational high school 121 (34.3\%) respondents with high school, $80(22.9 \%)$ respondents with college degrees, and 35 (9.9\%) respondents with university degree or more.

\section{Results}

First, we tested the validity of the questionnaire using Cronbach's alpha test, calculating the coefficients for the set of variables. We performed this test on variables that measured values and obtained the value of 0.859 , which indicates the high reliability of measurement (Cronbach, 1951) and, with regard to the composition and characteristics of the sample, we believe that it is representative.

\section{Factor Analysis}

With a larger number of variables in the survey, we have decided to conduct the factor analysis in order to create a smaller number of more manageable factors. When creating a survey, we intentionally formed some 
Table 1 Factor analysis of variables that measured organizational values

\begin{tabular}{|c|c|c|c|c|c|c|}
\hline \multirow[t]{2}{*}{ Variable } & \multicolumn{6}{|c|}{ Factor } \\
\hline & OVQ & OVI & OVE & OVEm & OvC & OVR \\
\hline Quality of work is important in our organization. & 0.942 & & & & & \\
\hline Within our org. we are focused on successfully completing our tasks. & 0.754 & & & & & \\
\hline Encouragement of positive examples is rare in our organization. & & 0.726 & & & & \\
\hline Inhibition of innovative ideas is frequent in our organization. & & 0.710 & & & & \\
\hline Adaptation to different business situations presents a problem for our org. & & & 0.659 & & & \\
\hline Immoral behaviour at work is acceptable in our organization. & & & 0.620 & & & \\
\hline In our organization we respect each other. & & & & 0.902 & & \\
\hline Employees in our organization interact. & & & & 0.622 & & \\
\hline In our organization we try to satisfy the needs of our customers. & & & & & 0.869 & \\
\hline Practices in our organization are focused on our costumers/guests. & & & & & -0.533 & \\
\hline At work in our organization we behave responsibly towards others around & us. & & & & & 0.723 \\
\hline To achieve the objectives within our organization we are working persiste & tly. & & & & & 0.210 \\
\hline
\end{tabular}

variables with a negative statement; these were recoded before the factor analysis was performed. However, we left the statements in their original form with regard to the text. Once we performed the factor analysis, we calculated six different factors with suitable weights. Factor analysis was performed with the extraction method principal axis factoring.

Within these six factors, 12 variables positioned themselves, while eight variables did not position themselves clearly in any of the factors and had weights in two or more factors with values of the weight being below the suppress point which was set at 0.200 . As a result, we decided to remove them entirely. Some might argue that the suppression point is low but, as indicated by Child (2006), this is acceptable for large enough samples. With the help of factor analysis, we were able to explain $67.76 \%$ of the variability of organisational values with these 12 variables in six factors; since all of the variables are latent variables, we decided to allow only two variables per factor based on the recommendation of Bollen (1989); the results are shown in Table 1. The six factors represent various values; we decided to name each of them in accordance to some common organisational values that are expressed in the sector (travel and leisure) in which conducted our research. Through the factor analysis, we also merged the variables that have positioned themselves in individual factors into new variables, thus we have a new variable we have labelled ove - Organisational value quality for the first factor, ov I Organisational value innovation for the second factor, OVE - Organisational value ethics for the third factor, ovem - Organisational value employees for the fourth factor, ovc - Organisational value customers for the fifth factor and OvR - Organisational value responsibility for the final sixth factor. The second variable in the last factor has a relatively low weight, being just above the cut-off point, but since it is the second variable and it is in the very last sixth factor, we have decided to use it.

We have further tested the validity of newly formed factors with Cronbach's alpha test, calculating the coefficients for each of newly formed factors. OVQ - Organisational value quality showed the value of 0.891 ; Ovi - Organisational value innovation showed the value of 0.647 ; OvE - Organisational value ethics showed the value of 0.591 ; OvEm - Organisational value employees showed the value of 0.792 ; OvC - Organisational value customers showed a value of 0.765 ; OVR - Organisational value responsibility showed a value of 0.769 . Although the values were lower than the values for all variables together, as expected, they 
Table 2 Independent Sample t-Test

\begin{tabular}{|c|c|c|c|c|}
\hline \multirow[t]{2}{*}{ Variable } & \multirow[t]{2}{*}{$t$} & \multirow[t]{2}{*}{$p$} & \multicolumn{2}{|c|}{ Mean } \\
\hline & & & Male & emale \\
\hline ovQ - Organizational value quality & -3.048 & 0.003 & 4.14 & 4.45 \\
\hline ovi - Organizational value innovation & -0.213 & 0.831 & 3.50 & 3.52 \\
\hline ove - Organizational value ethics & -1.059 & 0.290 & 3.82 & $3 \cdot 92$ \\
\hline OvEm - Organizational value employees & -0.020 & 0.984 & 3.64 & 3.65 \\
\hline ovc - Organizational value customers & -1.668 & 0.097 & 3.82 & 3.99 \\
\hline OVR - Organizational value responsibility & -2.313 & 0.022 & 3.97 & 4.20 \\
\hline
\end{tabular}

are still within the acceptable range based on (Cronbach, 1951). With factor analysis, we have also calculated the value of кмо at 0.870 , which indicated that sampling was adequate; furthermore, the $p$-value with Bartlett's test showed a value of 0.000 , which again confirms that factor analysis on the selected variables is appropriate for further use.

\section{Gender Differences Analysis}

Further, we have decided to see if there are any differences between male and female respondents regarding their perception of the importance of organisational values. For this stage, we decided to use an independent sample $t$-test; this text is based on the presumption that the two averages between groups are equal. For the sampled data, experimental value statistics are calculated, and, based on the result, the presumption is either confirmed or rejected; statistically significant or statistically insignificant differences between the two groups are thus obtained (Hodges \& Lehmann, 1956). The results are shown in Table 2. For variable OvQ Organisational value quality, there is a statistically significant difference $(t=-3.048 ; p=0.003)$. Male respondents evaluated this variable lower (mean value 4.14) than female respondents did (mean value 4.45). For the variable ov R - Organisational value responsibility, there is also a statistically significant difference $(t=-2.313 ; p=0.022)$; male respondents evaluated this variable lower (mean value 3.97) than female respondents did (mean value 4.40).

With all the other variables, it can be seen that there is no statistically significant difference, although with all variables it is apparent that female respondents
Table 3 Pearson's Correlation Coefficient

\begin{tabular}{lr}
\hline Variable & Age \\
\hline OVQ - Organizational value quality & -0.038 \\
OVI - Organizational value innovation & -0.005 \\
OVE - Organizational value ethics & -0.058 \\
OVEm - Organizational value employees & -0.091 \\
OVC - Organizational value customers & -0.011 \\
OVR - Organizational value responsibility & -0.010 \\
\hline
\end{tabular}

evaluated all the variables more highly than male respondents did.

\section{Age Differences Analysis}

In the next step, we decided to see if there is any correlation between organisational values and the age of the respondents. In this stage, we have calculated Pearson's correlation coefficient. This coefficient represents the size of linear correlations between variables $\mathrm{X}$ and Y. The coefficient is defined as the sum of all products of standard deviations of both values in relation to the degrees of freedom, or as the ratio of the covariance and the product of two standard deviations. The result obtained is one of the square roots (can be negative or positive); the correlation coefficient is the ratio of the explained variance and the total variance. The value of the Pearson correlation coefficient can be between values -1 and 1 . The value -1 represents a perfect negative correlation between variables; conversely, the value of 1 indicates a perfect positive correlation (Huck, 2015). The results for Pearson's correlation coefficient are shown in Table 3. 
There is no statistically significant correlation between the variables representing organisational values and the age of the respondents. All the correlations are negative and very weak. Furthermore, these same variables were tested with the help of ANOva based on a comparison to eight different age groups: up to 24 years of age, 25 to 29 years of age, 30 to 34 years of age, 35 to 39 years of age, 40 to 44 years of age, 45 to 49 years of age, 50 to 54 years of age, and 55 years of age or above. ANOva did not discover any other statistically significant differences among age groups.

\section{Practical Implications of Findings}

Today's working environment, especially in the hospitality sector, is very competitive and very demanding towards employees. For that reason, as much as possible about the relationship between organisational values and the demographics of employees must be understood in order to help managers organise work in a way that will simultaneously provide the maximum satisfaction of both guests and employees. Values of individuals, as well as organisational values, can be at the core of human resources management. This supports the idea of transforming the management style from Management By Objectives (м во) (Drucker, 2012) to Management By Values (MBV). Although M BV was previously discussed by others (Blanchard, O'Connor, \& Ballard, 1997), it was the contribution of (Dolan \& Garcia, 2002) and their further work (Dolan et al., 2006) that developed the theory as it is known today. Putting values at the forefront of management style can be a variation of management style, but it is essential to know who different (by gender and age) people perceive these same values.

Through our research, we have determined that gender does influence the perception of selected organisational values. Women evaluated the organisational value quality statistically significantly higher than their male counterparts did, which is congruent with the finding of (Kwun, 2011) and is a significant finding for management since it can be directly applied to the training of employees (giving male employees more training focus on attention to details), as well as the regular working environment (e.g., letting women oversee the quality of work). This will also directly af- fect the experience of customers, thus improving their satisfaction.

The second organisational value that showed statistically significant differences between men and women was that of responsibility; other researchers had similar findings (Kite et al., 2008; Rudman \& Phelan, 2008). This is a significant finding for managers since quality assurance must always be one of their top priorities in the fast-paced and highly competitive hospitality sector.

Further, we have analysed whether there are any statistically significant differences between different age groups; our findings show that there is no statistically significant difference; we contribute this finding to the relevant congruent population regarding the age distribution of our sample; thus, this could be a specific solely to Slovenia.

Service industries, such as hospitality, need to emphasise the quality of their product (Augustyn \& Ho, 1998) and responsibility towards customers (Holjevac, 2008) in order to achieve success. Knowing what we can do to help our employees achieve success is essential knowledge for managers that can be applied directly to working environments.

\section{Conclusion}

Knowledge of how organisational values are perceived by men and women, or how they are perceived by younger or older employees, can be used to achieve better organisational effectiveness, thus also increasing the satisfaction of the end customer - tourists. There is no clear answer about whether there are differences between men and women or younger and older in all the cases; it seems increasingly apparent that it is a case-by-case scenario. However, for the hospitality sector, where our research was conducted, the results that we have found are of great significance. The importance of quality and responsibility as organisational values are statistically significantly more highly evaluated by women in comparison to men. Given the fact that women are perceived as more altruistic, this is relatively expected. Although women represent over $60 \%$ of the entire population working in hospitality, they still face the so-called glass ceiling, not being found in higher executive positions within 
the industry, although this cannot be attributed to differences in education, hours worked, or occupational crowding (Sparrowe \& Iverson, 1999). Hospitality is focused on the nurturing of guests, providing them with the best possible experience. With this in mind, we can say that women have a gender-based predisposition that is beneficial for achieving precisely that. Managers should increase the involvement of women in duties that are marked by the need for quality assurance and responsible behaviour.

\section{References}

Allport, G. W. (1961). Pattern and growth in personality. New York, NY: Holt, Rinehart and Winston.

Ashforth, B. E., \& Mael, F. (1989). Social identity theory and the organization. Academy of Management Review, 14(1), 20-39.

Augustyn, M., \& Ho, S. K. (1998). Service quality and tourism. Journal of Travel Research, 37(1), 71-75.

Beutel, A. M., \& Marini, M. M. (1995). Gender and values. American Sociological Review, 6o, 436-448.

Blanchard, K. H., O’Connor, M. J., \& Ballard, J. (1997). Managing by values. San Francisco, NY: Berrett-Koehler Publishers.

Bollen, A. K. (1989). Structural equations with latent variables. New York, NY: Wiley.

Brown, E. A., Bosselman, R. H., \& Thomas, N. J. (2016). Are hospitality graduates making too many compromises? What they give up may lead to turnover. Journal of $\mathrm{Hu}$ man Resources in Hospitality \& Tourism, 15(2), 133-146.

Cha, S. E., \& Edmondson, A. C. (2006). When values backfire: Leadership, attribution, and disenchantment in a values-driven organization. The Leadership Quarterly, $17(1), 57-78$.

Chatman, J. A., \& Cha, S. E. (2003). Leading by leveraging culture. California Management Review, 45(4), 20-34.

Child, D. (2006). The essentials of factor analysis. London, England: Continuum.

Collins, J. C. (2001). Good to great: Why some companies make the leap ... and others don't. London, England: Random House.

Collins, J. C., \& Porras, J. I. (2005). Built to last: Successful habits of visionary companies. London, England: Random House.

Cronbach, L. J. (1951). Coefficient alpha and the internal structure of tests. Psychometrika, 16(3), 297-334.

Dearlove, D., \& Coomber, S. (1999). Heart and soul and millennial values. Skillman, NJ: Blessing/White.
Dietz, T., Kalof, L., \& Stern, P. C. (2002). Gender, values, and environmentalism. Social Science Quarterly, 83(1), 353364.

Dolan, S., \& Garcia, S. (2002). Managing by values: Cultural redesign for strategic organizational change at the dawn of the twenty-first century. Journal of Management Development, 21(2), 101-117.

Dolan, S., Garcia, S., \& Richley, B. (2006). Managing by values: A corporate guide to living, being alive, and making a living in the 21st Century. London, England: Palgrave Macmillan.

Drucker, P. (2012). The practice of management. London, England: Routledge.

England, G. W. (1967). Personal value systems of American managers. Academy of Management Journal, 10(1), 53-68.

Freeman II I, A. M., Herriges, J. A., \& Kling, C. L. (2014). The measurement of environmental and resource values: theory and methods. London, England: Routledge.

Guzzo, R. A., \& Salas, E. (1995). Team effectiveness and decision making in organizations. San Francisco, C A: JosseyBass.

Hannan, M. T., \& Freeman, J. (1977). The population ecology of organizations. American Journal of Sociology, 82(5), 929-964.

Hassan, A. (2007). Human resource development and organizational values. Journal of European Industrial Training, 31(6), 435-448.

Hodges Jr, J., \& Lehmann, E. (1956). The efficiency of some nonparametric competitors of the $t$-test. The Annals of Mathematical Statistics, 27(2) 324-335.

Hoerr, J. (1989). The payoff from teamwork. Business Week, $10,56-62$.

Hofstede, G. (1998). Attitudes, values and organizational culture: Disentangling the concepts. Organization Studies, 19(3), 477-493.

Holjevac, I. A. (2008). Business ethics in tourism as a dimension of TQM. Total Quality Management \& Business Excellence, 19(10), 1029-1041.

Holland, J. L. (1985). Vocational preference inventory. Odessa, FL: Psychological Assessment Resources.

Hsieh, Y.-C. J., Sönmez, S., Apostolopoulos, Y., \& Lemke, M. K. (2017). Perceived workplace mistreatment: Case of Latina hotel housekeepers. Work, 56(1), 55-65.

Huck, S. W. (2015). Statistical misconceptions. London, England: Routledge.

Jin, N., Line, N. D., \& Goh, B. (2013). Experiential value, relationship quality, and customer loyalty in full-service restaurants: The moderating role of gender. Journal of Hospitality Marketing \& Management, 22(7), 679-70o. 
Judge, T. A., \& Cable, D. M. (1997). Applicant personality, organizational culture, and organization attraction. Personnel psychology, 5o(2), 359-394.

Kač, S. M., Gorenak, I., \& Potočan, V. (2016). The influence of trust on collaborative relationships in supply chains. $E$ a M: Ekonomie a Management, 19(2), 120-131.

Kenny, T. (1994). From vision to reality through values. Management Development Review, 7(3), 17-20.

Kite, M. E., Deaux, K., \& Haines, E. L. (2008). Gender stereotypes. In F. L. Denmark and M. A. Paludi (Eds.), Psychology of women: A handbook of issues and theories (Vol. 2, pp. 205-236). Westport, C T: Praeger.

Kwun, D. J.-W. (2011). Effects of campus foodservice attributes on perceived value, satisfaction, and consumer attitude: A gender-difference approach. International Journal of Hospitality Management, 30(2), 252-261.

Lee, S. M., Olson, D. L., \& Trimi, S. (2012). Co-innovation: convergenomics, collaboration, and co-creation for organizational values. Management Decision, 50(5), 817831.

Lewin, K. (1951). Field theory in social science. New York, NY: Harper.

Marini, M. M., Fan, P.-L., Finley, E., \& Beutel, A. M. (1996). Gender and job values. Sociology of Education, 69(1), 4965.

Meglino, B. M., \& Ravlin, E. C. (1998). Individual values in organizations: Concepts, controversies, and research. Journal of management, 24(3), 351-389.

Musek Lešnik, K. (2008). Vrednote, poslanstvo in vizija podjetja. Koper: Fakulteta za management.

Parry, E., \& Urwin, P. (2011). Generational differences in work values: A review of theory and evidence. International Journal of Management Reviews, 13(1), 79-96.

Peters, T. J., Waterman, R. H., \& Jones, I. (1982). In search of excellence: Lessons from America's best-run companies. New York, Ny: Harper.

Pfeiffer, J. W., Goodstein, L. D., \& Nolan, T. M. (1985). Understanding applied strategic planning: A manager's guide. San Diego, c A: Pfeiffer \& Company.

Posner, B. Z. (2010). Another look at the impact of personal and organizational values congruency. Journal of Business Ethics, 97(4), 535-541.

Posner, B. Z., Kouzes, J. M., \& Schmidt, W. H. (1985). Shared values make a difference: An empirical test of corporate culture. Human Resource Management, 24(3), 293-309.
Prevolšek, B., Rozman, Č., Pažek, K., Maksimović, A., \& Potočnik Topler, J. (2017). Development of family tourism businesses in rural areas: Multi criteria assessment of businesses in easter Slovenia. Podravina: časopis za multidisciplinarna istraživanja, 16(32), 136-149.

Prince-Gibson, E., \& Schwartz, S. H. (1998). Value priorities and gender. Social Psychology Quarterly, 61(1), 49-67.

Rangus, M., \& Brumen, B. (2016). Development of tourism research. Teorija in praksa, 53(4), 929-941.

Rokeach, M. (1968). Beliefs, attitudes and values: A theory of organization and change. San Francisco, CA: Jossey-Bass.

Rokeach, M. (1973). The nature of human values. New York, NY: Free Press.

Rokeach, M., \& Ball-Rokeach, S. J. (1989). Stability and change in American value priorities, 1968-1981. American Psychologist, 44(5), 775.

Rudman, L. A., \& Phelan, J. E. (2008). Backlash effects for disconfirming gender stereotypes in organizations. Research in Organizational Behavior, 28, 61-79.

Schein, E. H. (1985). Organisational culture and leadership: A dynamic view. San Francisco, CA: Jossey-Bass.

Schwartz, S., \& Bilsky, W. (1987). Toward a universal psychological structure of human values. Journal of Personality and Social Psychology, 53(3), 550-562.

Simerly, R. (1987). Strategic planning and leadership in continuing education: Enhancing organizational vitality, responsiveness, and identity. San Francisco, CA: Jossey-Bass.

Sparrowe, R. T., \& Iverson, K. M. (1999). Cracks in the glass ceiling? An empirical study of gender differences in income in the hospitality industry. Journal of Hospitality \& Tourism Research, 23(1), 4-20.

Turnšek, M., \& Ladkin, A. (2017). Nova pravila igre za delavce? Airbnb in platformna ekonomija. Javnost/The Public, 24(sup1), s82-s99.

Ye, J. (2012). The impact of organizational values on organizational citizenship behaviors. Public Personnel Management, 41(5), 35-46.

This paper is published under the terms of the Attribution- NonCommercial-NoDerivatives 4.0 International (CC B Y-NC-ND 4.0) License. 


\title{
The Branded Hotel as an Element of Destination Branding
}

\author{
Elizabeth Abiola-Oke \\ Department of Transport and Tourism Studies, Redeemer's University, Nigeria \\ jacobe@run.edu.ng
}

The purpose of this article was to examine the effect of the availability of hotel brands in a destination on the promotion of the destination. Data for this study were collected through online questionnaires from a diverse population. The respondents were reached via a social medium (LinkedIn, on which the author has an account) and membership in different tourism-related and non-tourism related groups. The tourism-related groups are made up of both professionals in the field and nonprofessionals. The data were analysed using descriptive analysis (tables, cross tabulation, and Spearman ranked correlation) with spss. It was discovered that hotel brands have little impact on the choice of destination to visit in comparison to other elements of a destination, such as attraction, transportation, and other supporting services. Therefore, a hotel brand cannot be used as the sole element of destination branding as it has little or no effect on branding a destination.

Keywords: hotel branding, destination branding, destination marketing, destination promotion

https://doi.org/10.26493/2335-4194.12.83-96

\section{Introduction}

Accommodation in the forms of hotels, hostels, and other types are essential parts of a destination, and they create the feeling of welcome and a lasting impression on the tourists when they visit (Cooper, 2012). Anyone travelling to visit a destination away from their usual place of residence for any purpose requires accommodation. While some might have friends and family at the destination, some may not, but they both need a place to stay, especially when staying for more than a day. This contributes to the experience of the tourists at the destination, which is paramount for the promotion of the destination (Cooper, 2012). In addition, according to Ismail (2011), factors such as brand name, price, advertising, word of mouth, and experience determine the type of experience a customer would have on a product or services and also determines their loyalty. Hence, the importance of accommodation facilities at the destination.
Regarding how the brand of hotel in a destination determines the choice of a gaming destination, Dioko and So (2012) determined that the brand of hotel does not determine the choice of destination; they recommended a further study on the topic. Their study was limited to one destination (Macao); therefore, they said that a conclusive statement could be made on the topic and that to make a generalised statement, visitors to other destinations have to be surveyed. While accommodation providers are not the only service providers that make up the destination brand, from the perspective of the researcher, they are the major service provider without which destinations cannot be complete. According to Pike (2005); Morgan, Pritchard, and Piggott (2003), and Pritchard and Morgan (2001), destination branding is complex, as there are still many destinations yet to be studied in applying branding to the marketing principles of destinations (Dioko \& So, 2012). 
The following are the objectives of the research:

1. To know if the brands of hotels in the destination influence the choice of destination.

2. To examine the influence of hotel brand information on the promotion of tourism destinations.

\section{Research Hypotheses}

1. Accommodation facilities, in terms of their brand as a key element of a destination, have no effect on the inspiration for a choice of destination.

2. There is no significant relationship between loyalty to a hotel brand with the inspiration for the choice of a destination.

\section{Hotel Branding}

According to Medlik and Ingram (2000), hotels play essential roles in most countries by providing facilities for business transactions, for meetings and conferences, and for recreation and entertainment. As identified by Medlik and Ingram (200o), the hotel is both for accommodation and for the transaction of business. This is the aspect of the use of space, especially the lobbies and the lounges for purposes of meetings and business transactions. The hotel business as a service business operates to provide accommodation and other needs of the people during their stay (Bhatia, 2006). The mode of operation and revenue generation can be analysed from the way the business is structured, i.e., its organisational structure. The structure of any hotel would be based on its size, such as luxury hotel, economy/budget hotel, boutique hotels, lifestyle hotel (Freund de Klumbis, 2002); all of these also enhance the branding of a hotel based on the type of service it promises to deliver.

This is because the hospitality industry has grown over the years from the traditional hospitality service to a more comprehensive service - diverse in its operation (Berger \& Chiafor Jr., 2007). The industry includes accommodation, catering, and places for socialising (Nailon, 1982). Due to the change in the needs of people and for the enhancement of competition among operators, there is a need for the uniqueness of the organisations in the industry, and this is the essence of branding and other distinguishing concepts of marketing (Forsgren \& Franchetti, 2004). Branding is one of the concepts of differentiation (Dioko \& So, 2012) used by marketers in the industry.

Hotels have always been identified by their names, which shows that they held the common features of a product brand - the name (Connell, 1992). According to Olsen, Chung, Graf, Lee, and Madanoglu (2004), to capitalise on brand identification and differentiation in the face of competition, and to facilitate growth strategies, marketing executives have employed brand value, brand premium, brand equity, brand awareness, and brand image to enhance competition, from the aspect of management contracts and approaches to meet corporate goals. This affirms that branding is far more than merely having a name.

\section{Destination Branding}

Branding as a marketing concept also applies to destinations (Hankinson, 2005) because the products of tourism are also homogenous and there is a need for the identification of a unique factor for differentiation. Branding has gone beyond merely having a logo, sign, symbol, term, design, or combination of these (Blain, 2001). It has to do with the delivery of service to complement the name of the organisation and what they have to offer. According to Veríssimo, Tiago, Tiago, and Jardim (2017), destination branding is becoming a powerful marketing; this further emphasises the need for brand management.

\section{Brand Management}

Brand management is used in the construction of brand meaning, value, quality, personality and identity (Iglesias \& Bonet, 2012). According to Jevons, Gabbot, and De Chernatony (2005), brand meaning is influenced by the high level of influences, of which some can be controlled and some cannot but can be viewed and observed. It is essential, therefore, that the owners of brands ensure that high-quality service aligned with vision is delivered with a genuine commitment to the satisfaction of their customers (Blackett, 2004).

\section{Brand Identity}

Brand identity is the tangible aspect of the brand that can be seen and felt, ensures recognition, allows for 
differentiation, and makes the brand accessible (Alina, 2009). Brand identity, according to Kapferer (2008), is the internal construct of the product based on the view of the organisation in terms of what they want the brand to be. This requires stability and consistency to ensure that the brand is what it is intended for it to be (Da Silveira, Lages, \& Simoes, 2013). Brand identity can help the organisation in navigating and adapting to market changes (Da Silveira et al., 2013). In the opinion of Da Silveira et al. (2013), brand identity is not merely created by the organisation alone: it is essential to understand that the consumers also create the identity of the brand and this helps in the creation of value.

Just as the brand is an asset to the organisation, so too is the brand an investment for the consumers, and there has to be value gained that would be worth the investment made. Therefore, the argument of Kapferer (2008), asserting that brand identity emanates from the organisation and requires stability, can be said to be insufficient to explain brand identity as we are now in a global world with a dynamic environment. Consequently, for the survival of any brand, the identity should be made to suit the environmental condition as it changes. When the perspective of the consumers is viewed in the creation of an identity for the brand and the dynamism of the environment is also considered, the creation of brand identity will not be just from the internal perspective alone, and this would create a proper identity for the brand that will suit both the organisation and the consumers.

\section{Brand Value}

According to Aaker (1991), brand value is the awareness of the brand, its quality perception and the overall satisfaction the customers derives from making use of the brand. Chu and Keh (2006) pointed out that brand value is significant at two levels: the micro (consumer) and macro (firm) levels, each with different effects. On the consumer level, it positively affects the behavioural outcomes, including the intention to purchase (CobbWalgren, Ruble, \& Donthu, 1995), while at the firm level, it affects the perception of investors and the financial analysts, which subsequently determines the stock prices (Simon \& Sullivan, 1993).

\section{Brand Experience}

Brand experience is the feel of the brand that the consumers have when they make use of the brand. This is an essential part of brand management, and it can lead to brand loyalty, depending on whether the experience is positive or negative (Iglesias, Singh, \& Batista-Foguet, 2011). Brand experience is the impression taken away by the consumer (Carbone \& Haeckel, 1994) as a result of making use of the brand or having an encounter with it (Klaus \& Maklan, 2007). Good customer experience is essential to any business, and having a brand requires more from the brand owner. This is because it is assumed that any branded product is a promise of quality, and anything short of this is questionable.

\section{Brand Equity}

Brand plays a vital role in the promotion of a business, company or organisation, and to the customers as well. This is highlighted by Keller and Lehmann (2006) to being composed of three primary roles: the customer market, the product market, and the financial market. In the case of the consumer market, brands make it easy for the identification of products by the simplification of choice, the promise of quality to a particular level, and the reduction of risk and/or engendering trust. It plays a marketing role by ensuring effective marketing efforts; for the financial role, brands are assets (intangible) in a financial sense (Keller \& Lehmann, 2006). All value of these roles are the brand equity (Aaker, 1991). In the words of Randall (2000), brand equity is the value of the brand to both the consumers and the organisation that owns the brand. According to Morgan et al. (2003), the makeup (DNA) of a destination is expected to reflect the value of the brand and its unique propositions in the eyes of the customer.

\section{Brand Image}

The brand management components discussed above constitute an image for a brand; it us vital for any business to manage its brand appropriately. The prior perception of a brand image is created by the proper management of the brand, but the image created for the brand after the consumers' use of the brand is equally significant. This is because it is seen as an essential 
tool with the ability to influence the perception of the customer of a good or service offered, thereby having an impact on customer behaviour (Zeithaml \& Bitner, 1996).

Furthermore, image also influences the loyalty of customers to an organisation, their enthusiasm, and satisfaction depending on the type of image created in the minds of the customers (Kandampully \& Suhartanto, 2000; Binkowska, 2005). Branding is used to gain the loyalty of customers, but the image created in the mind of the people as regards the brand can either ensure loyalty or not; this is where brand management becomes important, as emphasised earlier. This is because branding is a form of promise made by the organisation to provide the service or products at a certain standard, distinct from others (Kotler \& Gertner, 2004). The concept of brand image is the examination of the overall information held by a consumer of a product/service brand including the brand quality and value (Ashton \& Scott, 2011). Branding, however, allows for differentiation in the marketplace and the creation of the image of the organisation in the mind of the people by creating value (Johnson \& Scholes, 2001).

According to Aaker (1991; 1996) and Keller (1998), the achievement of successful brand management is dependent on the enhancement of brand value or equity. Brand equity, according to Aaker (1991), is the value of a brand as a valuable company asset, to the consumer and the company. The value of a brand to the consumer is identified in the image created of such a brand in the mind of a consumer. According to Qu, Kim, and Im (2011), the image of a product/destination/service mediates between the brand associations, cognitive, affective, and unique image components and the future behaviour of buyers.

\section{Destination Marketing}

Pike (2008) defined a destination as a geographical space accommodating the existence of a cluster of tourism resources and being less of a political boundary. Furthermore, on the definition of a destination, Leiper (1995) defined a tourist destination as a place where people choose to visit for the purpose of having an experience of certain features of the destination, and Buhalis (2000) said it can also be viewed as a perpetual concept which can be interpreted by the tourists subjectively based on their experience, purpose of visit, cultural background, and psychographic and demographic characteristics (Periera, Correia, \& Schutz, 2012). Destinations are representations of the tourism industry as they are the place where the tourism activities occur and where the service providers of the industry are located to meet the needs of the tourists.

Marketing a destination, also known as place marketing, is a distinct task (Ashworth, 1993) and requires more complex managerial activities than the product does in its branding (Karavatsis \& Ashworth, 2005). Of all the products of tourism, the destination is one of the most difficult to manage and market (Fyall \& Leask, 2006) yet also the most important (Cooper, 2012). Destination marketing, according to Elbe, Hallen, and Axelsson (2009) is the deliberate strategically developed activities carried out in order to attract visitors to a destination. Due to the complexity of the nature of the destination, its marketing, as suggested by Helfert, Ritter, and Walter (2002), should be a relational approach. Even with the complexity of marketing destinations, Fyall and Garrod (2005) suggests that for destination marketing to be successful, it is necessary that the customers be engaged in the marketing activities and provide information about the experience they demand.

In line with the above, Dioko and So (2012) are of the opinion that for a relatively unknown destination, the entrance of international branded hotels enhances its marketing and the image of the places where new concepts of leisure and entertainments are introduced, and these are integrated with the core of accommodation services. This is also applicable to established and well-branded destinations. Furthermore, their findings confirmed this in the case of the Macao gaming centre. However, this can be seen as limited as as it was only tested on one particular gaming destination.

According to Cooper (2012), to effectively market a destination, branding of the destination is expedient for unique identification and differentiation among other destinations. This is also supported by Morgan, Pritchard, and Pride (2004), who consider destination branding to bea potent marketing tool, in con- 
trast to some researchers who find destination branding to be a complex concept. Therefore, Cai (2002) defined destination branding as a selection of consistent element mix of a destination used to identify and distinguish the destination among other destinations, while Gilmore (2002) sees destination branding as a re-positioning concept, and Curtis (2001) sees destination branding as the reconstruction of the destination (Park \& Petric, 2006).

The complexity of destination branding due to the nature of the destination and what is involved requires proper management: hence, the role of Destination Marketing Organisations (DMOs) as solely responsible for the marketing of the destination (Elbe et al., 2009). Part of the responsibilities of the DMO in promoting the destination is the branding of the destination. Although the destination is made up of individual service providers and other stakeholders, the Dmos are responsible for the promotion of the destination to tourists, known as destination marketing.

\section{Destination Promotion}

The survival of any business is dependent on meeting the needs of the people/customers as the needs and desires of the people are changing now due to their changing lifestyles and other environmental factors (Shoemaker \& Shaw, 2008). Branding is believed to help create an image in the minds of the guest, and that helps in the promotion of a hotel. It has also been proven by research that branding adds value to hotels than the usual contributors (O’Neill \& Xiao, 2006). The choice of a destination according to Kotler and Gertner (2004) begins with the collection of information before visiting the place and the ability to make sense of the information collected on the destination. Information about accommodation facilities available at the destination is one type of information that a tourist would seek before deciding, which can create an image of the destination in the mind of the tourist. Due to internationalisation, hotels of different brands can be found in different locations/destinations, which often attracts or has the potential to attract visitors. This, therefore, indicates the possibility of the two industries complementing each other.

In promoting tourism destinations, the various tourism enterprises have a role to play in creating an image of the destination. Aside from this fact on the promotion of a destination, customer experience is of utmost importance. No tourism enterprise can be without patronage from tourists and, for there to be patronage, the environment in which the organisation is located is of utmost importance. DMOs are charged with the responsibility of making a difference in the context of the growth of destination choices (Wahab \& Cooper, 2001; Stamboulis \& Skayannis, 2003; Pike, 2004).

\section{Research Methodology}

In carrying out this study, a survey research design was utilised. According to (MacDonald \& Headlam, n.d.), the survey research method is commonly used in collecting primary data, involves measurement procedures involving asking respondents questions, and they are flexible tools used in gathering both qualitative and quantitative data. Therefore, for this research, both quantitative and qualitative data was collected, thereby reflecting mixed method research. According to Creswell (2003), the mixed method is the process of the collection of both qualitative and quantitative data. It can also be seen as the combination of both numeric and narrative data in research (Aaron, 2011).

In collecting both the quantitative and qualitative data, as recommended by Bhattacherjee (2012), a combination of techniques is required, such as questionnaires, interviews, observation etc; alternatively, in the case of highly structured survey questionnaires, both qualitative and quantitative data can only be achieved by designing the questionnaire by using both closed-ended and open-ended questions. This has been adopted in carrying out this study. Therefore, the subjects of this are diverse and have in one time or the other visited different destinations. Because the questionnaire was uploaded online, there is no specified sample frame for the research, and the sample frame for an online questionnaire survey is based on convenience (Veal, 2011).

An online questionnaire was designed to collect both quantitative and qualitative data for the study, using Google Forms; the link to it was sent to respondents via LinkedIn, Facebook, and Twitter. As indi- 
cated earlier, Dioko and So (2012) carried out similar research on a destination. Hence, this study approached it from the perspective of obtaining respondents from diverse countries who had visited different destinations. Twenty-three questions were asked in the questionnaire using multiple choice questions and ranking questions for the closed-ended questions, and providing an avenue for the people to explain the choice of their answer to some of the closed-ended questions using the open-ended questions (Matthews \& Ross, 2010).

The questionnaire was divided into four sections. The first segment asked questions on the demographic characteristics of the respondent. This is to enable the researcher to develop an idea of the respondent, especially regarding their occupation and economic status. The second segment asked questions about the travel experience of the respondents to determine how often they travel and their opinions on the destinations they have visited. The third segment was based on the tourism destination features that influence the decisions of the respondents in their choice during their search on the destination to visit. This is in line with the opinion of Gartner (1993), who says that the image of a destination from the perspective of the tourists is influenced by the information they have on the destination.

In this segment of the questionnaire, five questions were asked; three of the five questions were ranking questions. Options were given, and the respondents were asked to rank them according to their opinion. The fourth segment asked questions on the hotel and destination choice of the respondents. In this segment, a question on the influence of hotel branding on the choice of destination was asked, regarding what would happen if the hotel brand to which they are loyal were unable to provide them with accommodation for them due to being fully booked. Options were provided for them to choose the action they would take.

\section{Analysis}

The data collected, both quantitative and qualitative, were analysed in the same manner. The data were analysed using both descriptive and inferential analysis with the aid of the Statistical Package for So- cial Sciences (SPSS). Descriptive analysis was used in analysing the frequency of responses and the profile of respondents. The inferential analysis was carried out using the Pearson Correlation co-efficient. According to Asuero, Sayago, and González (2006), the correlation coefficient is the measure of the degree of association between two variables. For this study, the Pearson Product-moment correlation was used to test for a linear relationship.

\section{Findings}

A total of 99 responses were collated due to the time constraints. The responses were analysed, and the following are the results of the findings.

\section{Descriptive Analysis}

A total of 99 respondents responded to the online questionnaire. Table 1 gives an overview of the demography of the respondents. Of the 99 respondents to the questionnaire, 39 were male, and 60 were females. The age of the respondents also varies, cutting across almost all age groups: $18-25$ years constituted $33.3 \%, 26-33$ years made up 33.3\%, 34-41 years constituted $13.1 \%$, 42-49 years made up 5.1\%, 50-57 years made up $6.1 \%$, while above 57 years were $9.1 \%$ of the respondents.

Regarding marital status, $55.6 \%$ of the respondents are singles, while $34.3 \%$ are married. The remaining are divorced, widowed and in relationships, constituting a total of $9 \%$, but one of the respondents did not fill in their marital status. Regarding the economic status of the respondents, the majority were in full-time paid work (40.4\%, 13.1\% worked part-time, 30.3\% are students (in full-time education), and the remaining are retired, unemployed and entrepreneurs making up a total of $16.2 \%$.

As stated in the methodology section, the research was targeted towards a diverse population from different countries around the world who have also visited different places around the world. Hence, Table 2 shows the diversity in the nationality of the participant, spanning almost all countries in the world. These people were contacted through the use of social media. 
Table 1 Respondents' Demography (\%)

\begin{tabular}{|c|c|c|}
\hline \multirow{2}{*}{$\begin{array}{l}\text { Travel in the last } \\
12 \text { months }\end{array}$} & Yes & 93 \\
\hline & No & 6 \\
\hline \multirow[t]{2}{*}{ Gender } & Male & 39 \\
\hline & Female & 60 \\
\hline \multirow[t]{6}{*}{ Age Range } & $18-25$ & 33 \\
\hline & $26-33$ & 33 \\
\hline & $34-41$ & 13 \\
\hline & $42-49$ & 5 \\
\hline & $50-57$ & 6 \\
\hline & 58 and above & 9 \\
\hline \multirow[t]{6}{*}{ Marital Status } & Single & 55 \\
\hline & Married & 34 \\
\hline & Divorced & 4 \\
\hline & Widow/widower & 2 \\
\hline & Other & 3 \\
\hline & Missing value & 1 \\
\hline \multirow[t]{6}{*}{ Economic Status } & In full-time paid work & 40 \\
\hline & In part-time paid work & 13 \\
\hline & In full-the education & 30 \\
\hline & Retired & 2 \\
\hline & Unemployed & 7 \\
\hline & Others - entrepreneur & 7 \\
\hline \multirow[t]{5}{*}{ Nationality } & African & 13 \\
\hline & Asians & 36 \\
\hline & Europeans & 41 \\
\hline & Americans & 8 \\
\hline & Australians & 1 \\
\hline \multirow{3}{*}{$\begin{array}{l}\text { No. of travel times } \\
\text { within } 12 \text { months }\end{array}$} & $1-4$ times & 80 \\
\hline & $5-8$ times & 13 \\
\hline & Above 8 times & 6 \\
\hline
\end{tabular}

To identify the type of accommodation the respondents make use of when they visit a destination, a question was asked on this and the responses indicated that $58.6 \%$ of the respondents make use of hotels, $14.1 \%$ makes use of hostels, $14.1 \%$ stays with family and friends, while $13.1 \%$ makes use of guest houses at the destination, as shown in Table 3. Following identification of the most used type of accommodation,
Table 2 Nationality of Participants

\begin{tabular}{|c|c|c|c|c|}
\hline Nationality & (1) & $(2)$ & (3) & (4) \\
\hline Middle East & 1 & 1.0 & 1.0 & 1.0 \\
\hline American & 2 & 2.0 & 2.0 & 3.0 \\
\hline Australian (perm. resident) & 1 & 1.0 & 1.0 & 4.0 \\
\hline Brazilian & 1 & 1.0 & 1.0 & 5.1 \\
\hline British & 16 & 16.2 & 16.2 & 21.2 \\
\hline Cameroonian & 1 & 1.0 & 1.0 & 22.2 \\
\hline Canadian & 5 & 5.1 & 5.1 & $27 \cdot 3$ \\
\hline Chinese & 7 & 7.1 & 7.1 & $34 \cdot 3$ \\
\hline Croatian & 1 & 1.0 & 1.0 & 35.4 \\
\hline Danish & 1 & 1.0 & 1.0 & 36.4 \\
\hline Dominican & 1 & 1.0 & 1.0 & $37 \cdot 4$ \\
\hline Dutch & 4 & 4.0 & 4.0 & 41.4 \\
\hline Egyptian & 1 & 1.0 & 1.0 & 42.4 \\
\hline Finnish & 1 & 1.0 & 1.0 & $43 \cdot 4$ \\
\hline French & 2 & 2.0 & 2.0 & 45.5 \\
\hline German & 3 & 3.0 & 3.0 & 48.5 \\
\hline Ghanaian & 1 & 1.0 & 1.0 & 49.5 \\
\hline Greek & 4 & 4.0 & 4.0 & 53.5 \\
\hline Indian & 3 & 3.0 & 3.0 & 56.6 \\
\hline Indonesian & 1 & 1.0 & 1.0 & 57.6 \\
\hline Iranian & 11 & 11.1 & 11.1 & 68.7 \\
\hline Italian & 3 & 3.0 & 3.0 & 71.7 \\
\hline Jamaican & 1 & 1.0 & 1.0 & 72.7 \\
\hline Latvian & 1 & 1.0 & 1.0 & 73.7 \\
\hline Malaysian & 12 & 12.1 & 12.1 & 85.9 \\
\hline Nigerian & 7 & 7.1 & 7.1 & 92.9 \\
\hline Polish & 1 & 1.0 & 1.0 & 93.9 \\
\hline Portuguese & 1 & 1.0 & 1.0 & 94.9 \\
\hline Serbian & 1 & 1.0 & 1.0 & 96.0 \\
\hline South African & 1 & 1.0 & 1.0 & 97.0 \\
\hline Spanish & 1 & 1.0 & 1.0 & 98.0 \\
\hline Ugandan & 2 & 2.0 & 2.0 & 100.0 \\
\hline Total & 99 & 100.0 & 100.0 & \\
\hline
\end{tabular}

Notes Column headings are as follows: (1) frequency, (2) percent, (3) valid percent, (4) cumulative percent.

a question was asked regarding the decision the respondents would make should their choice of ho- 
Table 3 Types of Accommodation Frequently Used

\begin{tabular}{|c|c|c|c|c|}
\hline Type of accommodation & (1) & (2) & (3) & (4) \\
\hline Hostel & 14 & 14.1 & 14.1 & 14.1 \\
\hline Guest house & 13 & 13.1 & 13.1 & $27 \cdot 3$ \\
\hline Hotels & 58 & 58.6 & 58.6 & 85.9 \\
\hline Stay with family and friends & 14 & 14.1 & 14.1 & 100.0 \\
\hline Total & 99 & 100.0 & 100.0 & \\
\hline \multicolumn{5}{|c|}{$\begin{array}{l}\text { Notes Column headings are as follows: (1) frequer } \\
\text { percent, (3) valid percent, (4) cumulative percent. } \\
\text { Table } 4 \text { Non-Availability of Preferred Hotel }\end{array}$} \\
\hline Solution & (1) & (2) & (3) & (4) \\
\hline $\begin{array}{l}\text { Look for another accommo- } \\
\text { dation within the destina- } \\
\text { tion }\end{array}$ & 83 & 83.8 & 83.8 & 83.8 \\
\hline $\begin{array}{l}\text { Postpone the trip till when I } \\
\text { can book for the accommo- } \\
\text { dation at the destination }\end{array}$ & 8 & 8.1 & 8.1 & 91.9 \\
\hline $\begin{array}{l}\text { Cancel the trip and search } \\
\text { for another destination with } \\
\text { the same hotel brand }\end{array}$ & 3 & 3.0 & 3.0 & 94.9 \\
\hline $\begin{array}{l}\text { Cancel the trip and look for } \\
\text { another destination }\end{array}$ & 5 & 5.1 & 5.1 & 100.0 \\
\hline Total & 99 & 100.0 & 100.0 & \\
\hline
\end{tabular}

Notes Column headings are as follows: (1) frequency, (2) percent, (3) valid percent, (4) cumulative percent.

tel/accommodation not be available for the date they intend to visit the destination: $83.8 \%$ indicated they would look for other accommodation within the destination, $8.1 \%$ said they would postpone the trip until they could get their preferred hotel, 3.0\% indicated they would cancel the trip and search for another destination with the same brand of hotel, while $5.1 \%$ indicated they would cancel the trip and look for another destination. This, therefore, shows that a total of $16.2 \%$ of the respondents are more loyal to the hotel brand. This is shown in Table 4.

Following the above question on a decision about the preferred hotel, a question on what inspires the choice of a destination was expedient was asked; $71.7 \%$ of respondants indicated that the attractions at the destination inspire them the most, $14.1 \%$ indicated that
Table 5 Inspiration for Choice of Destination

\begin{tabular}{|c|c|c|c|c|c|}
\hline \multicolumn{2}{|l|}{ Nationality } & (1) & (2) & (3) & (4) \\
\hline \multicolumn{2}{|c|}{ Attractions at the destination } & 71 & 71.7 & 71.7 & 71.7 \\
\hline \multicolumn{2}{|l|}{ Accessibility } & 14 & 14.1 & 14.1 & 85.9 \\
\hline \multicolumn{2}{|l|}{ Accommodation } & 6 & 6.1 & 6.1 & 91.9 \\
\hline \multicolumn{2}{|l|}{ Others } & 8 & 8.1 & 8.1 & 100.0 \\
\hline \multicolumn{2}{|l|}{ Total } & 99 & 100.0 & 100.0 & \\
\hline \multicolumn{6}{|c|}{$\begin{array}{l}\text { Notes Column headings are as follows: (1) frequency, (2) } \\
\text { percent, (3) valid percent, (4) cumulative percent. }\end{array}$} \\
\hline \multicolumn{6}{|c|}{$\begin{array}{l}\text { Table } 6 \text { Choice of Destination Inspiration } \\
\text { and Non-Availability of Preferred Hotel }\end{array}$} \\
\hline \multirow[t]{2}{*}{$\begin{array}{l}\text { Inspiration for } \\
\text { choice of destination }\end{array}$} & \multicolumn{5}{|c|}{$\begin{array}{l}\text { Decision when hotel preference } \\
\text { is not available }\end{array}$} \\
\hline & (1) & (2) & (3) & (4) & $(5)$ \\
\hline Attract. at the dest. & 60 & 6 & 1 & 4 & 71 \\
\hline Accessibility & 11 & 2 & o & 1 & 14 \\
\hline Accommodation & 5 & o & 1 & 0 & 6 \\
\hline Others & 7 & o & 1 & o & 8 \\
\hline Total & 83 & 8 & 3 & 5 & 99 \\
\hline
\end{tabular}

Notes Column headings are as follows: (1) look for another accommodation within the destination, (2) postpone the trip till when I can book for the accommodation at the destination, (3) cancel the trip and search for another destination with the same hotel brand, (4) cancel the trip and look for another destination, (5) total.

Table 7 Chi-Square Tests

\begin{tabular}{lrrr}
\hline Item & $(1)$ & $(2)$ & $(3)$ \\
\hline Pearson Chi-Square & 9.839 & 9 & 0.364 \\
Likelihood ratio & 9.159 & 9 & 0.423 \\
Linear-by-linear association & 0.003 & 1 & 0.960 \\
No. of valid cases & 99 & & \\
\hline
\end{tabular}

Notes Column headings are as follows: (1) value, (2) degrees of freedom, (3) asymptotic significance (2-sided).

accessibility to and within the destination is their inspiration, while just $6.1 \%$ indicated the accommodation facility available at the destination. The remaining 8.1\% indicated some other factors, such as cost, familiar people at the destination and culture of the destination, as indicated in Table 5. 
Table 8 Spearman's Ranked Correlation Analysis of Elements of Destination Branding and Inspiration for Choice of Destination

\begin{tabular}{|c|c|c|c|c|c|c|c|c|}
\hline Element & (1) & (2) & (3) & (4) & (5) & (6) & (7) & (8) \\
\hline \multirow[t]{3}{*}{ (1) Key attractions } & (a) & 1.000 & 0.195 & $0.273^{\star *}$ & $0.301^{\star *}$ & $0.264^{* *}$ & $0.306^{* *}$ & $0.368^{* *}$ \\
\hline & (b) & - & 0.054 & 0.006 & 0.002 & 0.008 & 0.002 & 0.000 \\
\hline & (c) & 99 & 99 & 99 & 99 & 99 & 99 & 99 \\
\hline \multirow[t]{3}{*}{ (2) Accommodation facilities } & (a) & 0.195 & 1.000 & $0.572^{* *}$ & $0.679^{\star *}$ & 0.076 & $0.416^{\star *}$ & 0.056 \\
\hline & (b) & 0.054 & - & 0.000 & 0.000 & 0.455 & 0.000 & 0.585 \\
\hline & (c) & 99 & 99 & 99 & 99 & 99 & 99 & 99 \\
\hline \multirow[t]{3}{*}{ (3) Infrastructure } & (a) & $0.273^{* *}$ & $0.572^{* *}$ & 1.000 & $0.663^{* *}$ & $0.203^{*}$ & $0.478^{\star *}$ & 0.144 \\
\hline & (b) & 0.006 & 0.000 & - & 0.000 & 0.044 & 0.000 & 0.156 \\
\hline & (c) & 99 & 99 & 99 & 99 & 99 & 99 & 99 \\
\hline \multirow[t]{3}{*}{ (4) Services and facilities } & (a) & $0.301^{\star *}$ & $0.679^{* *}$ & $0.663^{* *}$ & 1.000 & $0.225^{*}$ & $0.608^{\star *}$ & 0.152 \\
\hline & (b) & 0.002 & 0.000 & 0.000 & - & 0.025 & 0.000 & 0.132 \\
\hline & (c) & 99 & 99 & 99 & 99 & 99 & 99 & 99 \\
\hline \multirow[t]{3}{*}{ (5) Emotional appeal } & (a) & $0.264^{* *}$ & 0.076 & $0.203^{*}$ & $0.225^{*}$ & 1.000 & $0.315^{* *}$ & $0.400^{* *}$ \\
\hline & (b) & 0.008 & 0.455 & 0.044 & 0.025 & - & 0.001 & 0.000 \\
\hline & (c) & 99 & 99 & 99 & 99 & 99 & 99 & 99 \\
\hline \multirow[t]{3}{*}{ (6) Peace and Safety } & (a) & $0.306^{* *}$ & $0.416^{\star *}$ & $0.478^{* *}$ & $0.608^{\star *}$ & $0.315^{* *}$ & 1.000 & $0.250^{*}$ \\
\hline & (b) & 0.002 & 0.000 & 0.000 & 0.000 & 0.001 & - & 0.013 \\
\hline & (c) & 99 & 99 & 99 & 99 & 99 & 99 & 99 \\
\hline \multirow[t]{3}{*}{ (7) Scenic and Adventure } & (a) & $0.368^{* *}$ & 0.056 & 0.144 & 0.152 & $0.400^{* *}$ & $0.250^{\star}$ & 1.000 \\
\hline & (b) & 0.000 & 0.585 & 0.156 & 0.132 & 0.000 & 0.013 & - \\
\hline & (c) & 99 & 99 & 99 & 99 & 99 & 99 & 99 \\
\hline \multirow[t]{3}{*}{ (8) Inspiration for choice of destination } & (a) & $-0.227^{*}$ & 0.055 & -0.062 & 0.035 & 0.119 & -0.023 & -0.054 \\
\hline & (b) & 0.024 & 0.586 & 0.541 & 0.733 & 0.240 & 0.821 & 0.597 \\
\hline & (c) & 99 & 99 & 99 & 99 & 99 & 99 & 99 \\
\hline
\end{tabular}

Notes Row headings are as follows: (a) correlation coefficient, (b) significance (2-tailed), (c) N.

\section{Cross Tabulations and Correlation Analysis}

In continuation of the descriptive analysis, cross tabulation was used in analysis of both the decision the respondents will make when their preferred hotel is not available and the inspiration for their choice of hotel. Table 6 is a cross-tabulation of the two variables showing a summary of the relationship between them. From the table, it can be summarised that those who will look for other accommodation within the same destination are more interested in the attraction rather than the accommodation, and they constitute the majority in the cross tabulation.
To test the hypothesis, Spearman Rank Correlation analysis was used. The hypothesis for this research states that accommodation facilities in terms of its brand as a key element of destination have no effect on the inspiration for a choice of destination. According to the analysis of data presented in Table 8 , the relationship between accommodation facilities as an element of destination branding and the inspiration for a choice of destination is a weak relationship with $r=0.055$ and $p=0.586$; therefore, the null hypothesis is accepted, which means that there is no significant relationship between accommodation fa- 
Table 9 Correlation of Destination Brand and Hotel Brand

\begin{tabular}{llrr}
\hline Item & & $(1)$ & $(2)$ \\
\hline (1) Inspiration for choice & (a) & 1.000 & 0.020 \\
of destination & (b) & - & 0.843 \\
& (c) & 99 & 99 \\
\hline (2) Decision when hotel & (a) & 0.020 & 1.000 \\
preference is not available & (b) & 0.843 & - \\
& (c) & 99 & 99 \\
\hline
\end{tabular}

Notes Row headings are as follows: (a) correlation coefficient, (b) significance (2-tailed), (c) $N$.

cilities as a brand element for a destination and being an inspiration for the choice of destination to visit. Regarding other elements of destination branding and inspiration to travel, it is indicated in Table 6 that the emotional appeal of the destination to the tourists is more related to why people choose a destination with $r=0.119$ but it is not significant as $p=0.240$. From the analysis on the table, it can then be concluded that no individual element of destination branding can solely enhance the branding of a destination nor influence the decision of the choice of a destination, hence, all elements are important.

In a test of loyalty to hotel brand or destination brand, Spearman Rank Correlation analysis was used. The hypothesis states that there is no significant relationship between the loyalty to a hotel brand with the inspiration for the choice of a destination. The report of the analysis supports the research hypothesis that there is no statistically significant relationship between the two, as presented in Table 9 where $r=0.020$ and $p$ $=0.843$.

\section{Discussion}

As identified in the literature review, the marketing of a destination, also known as 'place marketing' is more complex than the marketing of other organisations, such as the hotels or transport service providers (Karavatsis \& Ashworth, 2005). Therefore, Echtner and Ritchie (2003) indicated that, for the successful promotion of the destination in the targeted markets, the destination must be differentiated from its competition. As a way of differentiating one destination from its competition, the availability of a branded hotel at the destination was assumed to be a differentiating factor (Dioko \& So, 2012), but from the finding, the availability of branded hotel does not influence their choice of destination. To some of the respondents, the availability of branded hotels in a destination indicates the quality of the destination, and it gives assurance of value, safety, quality service, assurance of comfortability, which makes it a significant part of the whole travel experience. Therefore, the availability of branded hotels can be seen as an added advantage in the promotion of the destination, which can also create an image of the destination as supported by Gilmore (2002), who sees destination branding as a re-positioning concept, and Curtis (2001), who sees destination branding as the reconstruction of the destination (Park \& Petric, 2006).

From the research findings, it was discovered that all the elements of destination branding are essential to the tourists and the enhancement of the brand of a destination (see Table 10) as supported by Cai (2002) who defined destination branding as a selection of a consistent element mix of a destination used to identify and distinguish the destination among other destinations. Therefore, according to Miličević, Mihalič, and Ivan (2016), in branding a destination, the managers of the destinations are expected to define their target group (i.e., to whom to communicate the destination brand). For some groups, the availability of branded hotels might not be a important element they seek in the brand of a destination, while to some it might be. It was noted that some people find the availability of branded hotels to be an assurance of the quality of the destination brand. Hence, the fact of a hotel brand as an element of destination branding cannot be totally neglected in the branding of a destination, according to Miličević et al. (2016).

Furthermore, in the test of loyalty to either the destination brand or hotel brand, it was discovered that the respondents are more loyal to the destination than the brand of hotel; this also indicates that the brand of the hotel cannot be considered to be a major branding element for a destination. According to Veríssimo et al. (2017), there are two dimensions to be considered in evaluating brand loyalty: emotional and rational di- 
Table 10 Elements of Destination Branding

\begin{tabular}{|c|c|c|c|c|c|c|c|}
\hline Elements & (1) & (2) & (3) & (4) & (5) & (6) & (7) \\
\hline$N$ valid & 99 & 99 & 99 & 99 & 99 & 99 & 99 \\
\hline$N$ missing & $\mathrm{o}$ & $\mathrm{o}$ & $\mathrm{o}$ & $\mathrm{o}$ & $\mathrm{o}$ & $\mathrm{O}$ & $\mathrm{o}$ \\
\hline Mean & 4.38 & 3.72 & 3.55 & 3.83 & 4.14 & 4.26 & 4.16 \\
\hline Median & 5.00 & 4.00 & 4.00 & 4.00 & 4.00 & 5.00 & 4.00 \\
\hline Mode & 5 & 5 & 3 & 4 & 5 & 5 & 5 \\
\hline Standard deviation & 0.955 & 1.116 & 1.013 & 0.969 & 1.010 & 0.985 & 0.900 \\
\hline Variance & 0.912 & 1.246 & 1.026 & 0.940 & 1.021 & 0.971 & 0.810 \\
\hline Range & 4 & 4 & 4 & 4 & 4 & 4 & 4 \\
\hline Sum & 434 & 368 & 351 & 379 & 410 & 422 & 412 \\
\hline
\end{tabular}

Notes Column headings are as follows: (1) key attractions, (2) accommodation facilities, (3) infrastructure, (4) services and facilities, (5) emotional appeal, (6) peace and safety, (7) scenic and adventure.

mensions. These have been embedded in the questions on the decisions the respondents will make when their preferred brand of hotel is not available at the destination of interest, and also in the question on the inspiration of choice of destination to visit. Therefore, these variables are applicable as a test of loyalty to either the destination brand or hotel brand. The result of the finding can be said to be justified as this can be linked to brand equity as supported by Aaker (1996) who stated that loyalty is a core aspect of brand equity because it is able to reduce vulnerability of a destination to competitor's actions.

\section{Conclusion}

The study was carried out to identify the role of hotel brand on the branding of a destination, but the findings demonstrated that a branded hotel or accommodation facility available at the destination does not solely enhance the branding of a destination; rather, a combination of some elements does, as identified in Table 8. This, therefore, further supports the findings of Pike and Page (2014), who said the most comprehensive definition of destination branding has been that proposed by Blain, Levy, and Ritchie (2005), in collaboration with Berthon, Hulbert, and Pitt's (1999) model of the functions of a brand from the buyer and supplier's perspectives, which is given as: 'the set of marketing activities (1) that support the creation of a name, symbol, logo, word mark or other graphic that readily identifies and differentiates a destination; that (2) consistently convey the expectation of a memorable travel experience; (3) serve to consolidate and reinforce the emotional connection between the visitor and the destination; and (4) reduce consumer search costs and perceived risk.'

All of these activities collectively serve to create a destination image that positively influences consumer destination choice. In line with this, the research findings also show that tourists are more loyal to the destination brand than the hotel brand.

\section{References}

Aaker, D. A. (1991). Managing brand equity. New York, NY: The Free Press.

Aaker, D. A. (1996). Building strong brands. New York, NY: The Free Press.

Aaron, L. (2011). Mixed methods research. Radiology and Technology, 82(3), 274-275.

Alina, W. (2009). Designing brand identity: An essential guide for the entire branding team. Hoboken, NJ: Wiley.

Ashton, A. \& Scott, N. (2011). Hotel restaurant co-branding: The relationship of perceived brand fit with the intention to purchase. Journal of Vacation Marketing, 17(4), 275285.

Asuero, A. G., Sayago, A., \& González, A. G. (2006). The correlation coefficient: An overview. Critical Reviews in Analytical Chemistry, 36(1), 41-59.

Ashworth, G. (1993). Marketing places: What are we doing? In G. Ave, \& F. Corsico (Eds.), Urban marketing in Europe (pp. 643-649). Turin, Italy: Turina Incontra. 
Berger, B., \& Chiafor, Jr. (2007). Select-service hotels: A guide to understanding the lodging industry and one of its most attractive segments (Unpublished master thesis). Cambridge, m A: Massachusetts Institute of Technology.

Bhatia, A. K. (2006). The business of tourism: Concepts and strategies. New York, NY: Sterling.

Bhattacherjee, A. (2012). Social science research: Principles, methods, and practices. Tampa, FL: Open Textbook Library.

Berthon, P., Hulbert, J., \& Pitt, L. (1999). To serve or to create? Strategic orientations towards customers and innovation. California Management Review, 42(1), 37-58.

Binkowska, B. (2005). The New Zealand hotel industry: The role of image as a medium influencing company's competitiveness and customer loyalty towards brand (Unpublished masters thesis). Auckland, New Zealand: University of Technology.

Blackett, T. (2004). What is a brand. In R. Clifton \& J. Simmons (Eds.), Brands and Branding (pp. 13-26). London, England: Profile Books.

Blain, C. R. (2001). Destination branding in destination marketing organizations (Unpublished master thesis). University of Calgary, Calgary, Canada.

Blain, C., Levy, S. E., \& Ritchie, J. R. B. (2005). Destination branding: Insights and practices from destination management organizations. Journal of Travel Research, 43, 328-338.

Buhalis, D. (2000). Marketing the competitive destination for the future. Tourism Management, 21(1), 97-116.

Cai, L. (2002). Cooperative branding for rural destinations. Annals of Tourism Research, 29(3), 720-742.

Carbone, L. P., \& Haeckel, S. H. (1994). Engineering customer experiences. Marketing Management, 3(3), 9-19.

Chu, S., \& Keh, H. (2006). Brand value creation: Analysis of the Interbrand-Business Week brand value ranking. Marketing Letters, 17(1), 323-331.

Cobb-Walgren, C. J., Ruble, C. A., \& Donthu, N. (1995). Brand equity, brand preference, and purchase intent. Journal of Advertising, 24(Fall), 25-40.

Connell, J. (1992). Branding hotel portfolios. International Journal of Contemporary Hospitality Management, 4(1), 26-32.

Cooper, C. (2012). Essentials of tourism. Harlow, England: Pearson.

Creswell, J. W. (2003). Research design: Qualitative, quantitative, and mixed methods approaches (2nd ed.). Thousand Oaks, c A: Sage.

Curtis, J. (2001). Branding a state: The evolution of brand Oregon. Journal of Vacation Marketing, 7(1), 75-81.
Da Silveira, C., Lages, C., \& Simoes, C. (2013). Reconceptualizing brand identity in a dynamic environment. Journal of Business Research, 66(1), 28-36.

Dioko, L., \& So, S. (2012). Branding destinations versus branding hotels in a gaming destination: Examining the nature and significance of co-branding effects in the case study of Macao. International Journal of Hospitality Management, 31(2), 554-563.

Elbe, J., Hallen, L., \& Axelsson, B. (2009). The destinationmanagement organization and the integrative destination-marketing process. International Journal of Tourism Research, 11(3), 283-296.

Echtner, C., \& Ritchie, J. R. (2003). The meaning and measurement of the destination image. The Journal of Tourism Studies, 14(1), 37-48.

Forsgren, F., \& Franchetti, C. (2004). The marketing role of unique concepts for hotels in Sweden (Unpublished masters thesis). Göteborg, Sweden: Göteborg University.

Freund de Klumbis, D. (2002, April). Seeking the ultimate hotel experience. Peper presented at the 12th International Leisure and Tourism Symposium, Barcelona.

Fyall, A., \& Garrod, B. (2005). Tourism marketing: A collaborative approach. Clevedon, U K: Channel View Publications.

Fyall, A., \& Leask, A. (2006). Destination marketing: Future issues - strategic challenges. Tourism and Hospitality Research, $7(1), 50-63$.

Gartner, W. C. (1993). Image formation process. Journal of Travel and Tourism Marketing, 2(2-3), 191-215.

Gilmore, F. (2002). Branding for success. In N. Morgan, A. Pritchard, \& R. Pride (Eds.), Destination branding: Creating the unique destination proposition (pp. 57-65). Oxford, England: Butterworth Heinemann.

Hankinson, G. (2005). Destination brand images: A business tourism perspective. Journal of Service Marketing, 19(1), 24-32.

Helfert, G., Ritter, T., \& Walter, A. (2002). Redefining market orientation from a relationship perspective: Theoretical considerations and empirical results. European Journal of Marketing, 36, 1119-1139.

Iglesias, O. \& Bonet, E. (2012). Persuasive brand management: How managers can influence brand meaning when they are losing. Journal of Organizational Change Management, 25(2), 251-264.

Iglesias, O., Singh, J. J., \& Batista-Foguet, J. M. (2011). The role of brand experience and affective commitment in determining brand loyalty. Journal of Brand Management, 18(8), 570-582.

Ismail, A. R. (2011). Experience marketing: An empirical in- 
vestigation. Journal of Relationship Marketing, 10(3), 167201.

Jevons, C., Gabbott, M., \& De Chernatony, L. (2005). Customer and brand manager perceptions on brand relationships: A conceptual framework. The Journal of Product and Brand Management, 14(4/5), 300.

Johnson, G., \& Scholes, K. (2001). Exploring corporate strategy. Hemel Hempstead, England: Prentice Hall.

Kandampully, J., \& Suhartanto, D. (2000). Customer loyalty in the hotel industry: The role of customer satisfaction and image. International Journal of Contemporary Hospitality Management, 12(6), 346-351.

Karavatsis, M., \& Ashworth, G. (2005). City branding: An effective assertion of identity or a transitory marketing trick? Tijdschrift voor Economische en Social Geografie, 96(5), 506-514.

Kapferer, J. N. (2008). The new strategic brand management: Creating and sustaining brand equity long term. London, England: Kogan Page.

Keller, K. L. (1998). Strategic brand management: Building, measuring and managing brand equity. Upper Saddle River, NJ: Prentice Hall.

Keller, K., \& Lehmann, D. (2006). Brands and branding: Research findings and future priorities. Marketing Science, 25(6), 740-759.

Klaus, P., \& Maklan, S. (2007). The role of brands in a service-dominated world. Journal of Brand Management, 15(2), 115-122.

Kotler, P., \& Gertner, D. (2004). Country as a brand, product and beyond: A place marketing and brand management perspective. In N. Morgan, A. Pritchard, \& R. Pride (Eds.), Destination branding: Creating the unique destination proposition. Oxford, England: ButterworthHeinemann.

Leiper, N. (1995). Tourism management. Melbourne, Australia: RMIT Press.

MacDonald, S. \& Headlam, N. (N.d). Research methods handbook: Introductory guide to research methods for social research. Manchester, England: CLES.

Matthews, B., \& Ross, L. (2010). Research methods. London, England: Pearson Longman.

Medlik, S., \& Ingram, H. (200o). The business of hotels. Oxford, England: Butterworth-Heinemann.

Miličević, K., Mihalič, T., \& Ivan, S. (2016). An investigation of the relationship between destination branding and destination competitiveness. Journal of Travel \& Tourism Marketing, 34(2), 209-221.

Morgan, N. J., Pritchard, A., \& Piggott, R. (2003). Destination branding and the role of the stakeholders: The case of New Zealand. Journal of Vacation Marketing, 9(3), 285-299.

Morgan, N., Pritchard, A., \& Pride, R. (2004). Destination branding: Creating the unique destination proposition. Oxford, England: Butterworth Heinemann.

Nailon, P. (1982). Theory in hospitality management. International Journal of Hospitality Management, 1(3), 135143.

Olsen, M. D., Chung, Y., Graf, N., Lee, K., \& Madanoglu, M. (2004). Branding: Myth and reality in the hotel industry. Journal of Retail and Leisure Property, 4(2), 146-162.

O'Neill, J., \& Xiao, Q. (2006). The role of brand affiliation in hotel market value. Cornell Hospitality Quarterly, 47(3), 210-223.

Park, S., \& Petric, J. (2006). Destinations' perspectives of branding. Annals of Tourism Research, 33(1), 262-265.

Periera, R., Correia, A., \& Schutz, R. (2012). Destination branding: A critical overview. Journal of Quality Assurance in Hospitality and Tourism, 13(2), 81-102.

Pike, S. (2004). Destination marketing organisations. Oxford, England: Elsevier.

Pike, S. (2005). Tourism destination branding complexity. The Journal of Product and Brand Management, 14(4/5), 258.

Pike, S. (2008). Destination marketing: An integrated marketing communication approach. Amsterdam, The Netherlands: Butterworth-Heinemann.

Pike, S., \& Page, S. (2014). Destination marketing organizations and destination marketing: A narrative analysis of the literature. Tourism Management, 41, 202-227.

Pritchard, A., \& Morgan, N. J. (2001). Culture, identity, and tourism representation: Marketing Cymru or Wales? Tourism Management, 22(2), 167-179.

Qu, H., Kim, L. H., \& Im, H. H. (2011). A model of destination branding: Integrating the concepts of the branding. Tourism Management, 32(3), 465-476.

Randall, G. (2000). Branding: A practical guide to planning your strategy. London, England: Kogan Page.

Shoemaker, S., \& Shaw, M. (2008). Marketing essentials in hospitality and tourism: Foundations and practices. Upper Saddle River, NJ: Pearson Prentice Hall.

Simon, C. J., \& Sullivan, M. W. (1993). The measurement and determinants of brand equity: A financial approach. Marketing Science, 12(Winter), 28-52.

Stamboulis, Y., \& Skayannis, P. (2003). Innovation strategies and technology for experience-based tourism. Tourism Management, 24(1), 34-43.

Veal, A. (2011). Research methods for leisure and tourism: A practical guide. Harlow, England: Pearson. 
Veríssimo, J. M. C., Tiago, M. T. B., Tiago, F. G., \& Jardim, J. S. (2017). Tourism destination brand dimensions: An exploratory approach. Tourism and Management Studies, 14(4), 1-8.

Wahab, S., \& Cooper, C. (2001). Tourism, globalisation and the competitive advantage of nations. In S. Wahab, \& C. Cooper (Eds.), Tourism in the age of globalisation (pp. 321). London, England: Rouledge.
Zeithaml, V. A., \& Bitner, M. J. (1996). Services marketing. New York, NY: McGraw-Hill.

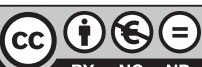

This paper is published under the terms of the Attribution- NonCommercial-NoDerivatives 4.0 International (CC B Y-NC-ND 4.0) License. 


\section{Obiskovalci grških termalnih in obmorskih zdravilišč (od sredine 19. do zgodnjega 20. stoletja) Melina Kostidi}

Termalni turizem, ki velja za prvo obliko turizma v Grčiji, se je pričel razvijati v 19. stoletju, ko so prvi obiskovalci začeli obiskovati termalne kopeli, da bi ozdraveli ali vsaj olajšali svoje bolečine. Prva termalna zdravilišča v Grčiji imamo lahko za nekakšne "zamudnike«, saj se je njihov razvoj pričel kasneje kot v drugih evropskih državah, njihova infrastruktura pa je bila relativno skromna. Že sredi devetnajstega stoletja pa se je urbani prostor grških termalnih in obmorskih središč začel arhitekturno preoblikovati zaradi ukrepov državne politike in vse večjega števila obiskovalcev. V prispevku sta prikazana arhitekturna preobrazba grških zdravilišč in profil obiskovalcev ter bolnikov v dveh fazah njihovega razvoja. Raziskovanje je temeljilo na primarnih virih iz 19. stoletja (zakonodaja in predpisi, registri bolnikov, zdravniška poročila, oglasi, razglednice, romani in spomini). V prvi fazi razvoja (1833-189o) so imela grška letovišča zelo omejene nastanitvene in prostočasne zmogljivosti. Obiskovali so jih bolniki in popotniki iz bližnjih krajev, ki so se srečevali s pomanjkanjem ustrezne zdravstvene oskrbe in nastanitvenih zmogljivosti. V naslednji fazi (18901930) se je urbani prostor grških zdravilišč preoblikoval, da bi zadostil potrebam in pritegnil nove obiskovalce. Obiskovalci grških zdravilišč so bili pacienti in turisti, ki so običajno potovali $\mathrm{z}$ drugimi družinskimi člani. Trgi in sprehajališča v termalnih kopališčih in obmorskih letoviščih so postali osrednji prostor urbane družabnosti gostov, ki so bili nastanjeni v luksuznih hotelih in so uživali v ponudbi restavracij, gledališč in igralnic.

Ključne besede: zdravilišča, obmorska letovišča, prosti čas, turizem, Grčija

Academica Turistica, 12(1), 5-12

\section{Zabava in gospodarske dejavnosti - tekmeca na obalah zgodnjih angleških obmorskih letovišč}

Allan Brodie

Prva angleška letovišča so se razvila v začetku 18. stoletja v manjših obalnih krajih, kjer sta pred tem cvetela trgovina in ribištvo. Tudi danes se obmorska letovišča nahajajo v bližini pristanišč različnih velikosti, od manjših ribiških pristanišč ali pristanov za manjša plovila do velikih kontejnerskih in trajektnih pristanišč. V večini sodobnih mest se industrijska območja nahajajo na obrobju urbanih naselij, na območjih, kjer so bili v 18. in 19. stoletju zgrajeni prvi mlini in tovarne. Nasprotno pa ležijo pristanišča v neposredni bližini starih mestnih jeder obalnih krajev, ki so kasneje postala turistično privlačna, pristaniška dejavnost pa poteka vzporedno z novo turistično dejavnostjo, ki je spremenila identiteto teh mest. Ta soobstoj različnih dejavnosti lahko vodi v konflikt med interesi turizma in drugih gospodarskih dejavnosti oz. do napetosti med gosti in zaposlenimi, ki delajo v pristaniški in pomorskih podjetjih. Prostorski in gospodarski interesi turizma ter trgovske dejavnosti so se v 300 letih soobstoja izoblikovali pod vplivom povečevanja števila obiskovalcev in rasti trgovske dejavnosti. V članku so predstavljeni pristaniški kraji v Angliji in Walesu, ki so v 18. 
stoletju pričeli razvijati kopališko ponudbo in infrastrukturo. Nekateri so se razvili v današnje obmorske turistične destinacije, drugi pa so ohranili pristaniško dejavnost. Le nekaj krajev je uspelo ohraniti krhko ravnotežje v razvoju obeh dejavnosti.

Ključne besede: prosti čas, trgovina, obmorska letovišča

Academica Turistica, 12(1), 13-22

\section{Mesto in morje: razvoj in preoblikovanje težavnega razmerja Annarita Teodosio}

V preteklih stoletjih se je odnos mest do morja pogosto spreminjal. Različni dejavniki (politični, gospodarski, socialni, znanstveni) so vplivali na človekovo dojemanje morja. Sčasoma je obala izgubila podobo nevarnega področja in je postala poslovno zanimiva. V zadnjih letih smo priča rušenju starih, odsluženih objektov, izgradnji obalnih sprehajališč in odpiranju prostora proti morju, s čimer se spreminja tradicionalna podoba obmorskih krajev. Gospodarska kriza v sedemdesetih letih preteklega stoletja je povzročila opuščanje številnih industrijskih in pristaniških dejavnosti, kar je povzročilo degradacijo obalnih območij. V osemdesetih letih prejšnjega stoletja so $\mathrm{v}$ številnih krajih pričeli pripravljati in izvajati različne ukrepe za obnovo in revitalizacijo teh degradiranih območij. Kljub različnim pristopom in obsegu teh projektov pa so bili njihovi cilji podobni - ponovna vzpostavitev povezave med mestom in morjem ter ustvarjanje novih priložnosti za urbano, gospodarsko in družbenokulturno rast. V prispevku so predstavljeni ključni koraki dolgotrajnega in kompleksnega procesa odpiranja proti morju. Predstavljena je tudi analiza preobrazbe obale iz zgodovinskega sprehajališča devetnajstega stoletja v osrednjo točko mestnega, gospodarskega in turističnega razvoja. Predstavljene so bogate izkušnje z zapuščenimi in revitaliziranimi pristanišči velikih in znanih mest, kot sta na primer Barcelona in Bilbao, kakor tudi z manjšimi kraji, kakršen je na primer Vigo, ter nekaj italijanskimi kraji. Današnja mesta iščejo novo identiteto, alternativne poti ter načine okoljske, socialne in gospodarske vzdržnosti razvoja.

Ključne besede: obalna mesta, promenada, oživljanje obale Academica Turistica, 12(1), 23-30

\section{Vstop turizma v pomorsko pristanišče: primer Brionov v času Habsburške monarhije}

Nataša Urošević

Prispevek predstavlja rezultate arhivskega in terenskega raziskovanja v okviru avtorskega raziskovalnega projekta »Valorizacija skupne evropske dediščine Pulja kot nekdanjega glavnega avstrijskega pomorskega pristanišča in otočja Brioni kot elitnega letovišča«; raziskava je bila opravljena v avstrijskih arhivih in temelji predvsem na zbirki Kupelwieser, ki jo hrani Avstrijska nacionalna knjižnica. Namen raziskave je bil oceniti vlogo aristokratskih rezidenc, postavljenih v bližini glavnega vojaškega pomorskega pristanišča, pri začetkih razvoja sodobnega turizma na Brionih, pri čemer je bila analiza primerjalna in je upoštevala tudi mednarodni okvir. Glavno 
raziskovalno vprašanje je bilo, ali so Brioni sledili evropskemu modelu razvoja aristokratskih letovišč v bližini velikih pristanišč. V primerjalno študijo, ki je zajemala dokumentarno in terensko raziskovanje, so bile zajete znane otoške aristokratske rezidence v Evropi in Sredozemlju, ki so se razvile kot priljubljena obmorska letovišča v 19. in 20. stoletju, kot so otoki Wight, Mallorca, Krf in Brioni. Pregled sodobne znanstvene literature je dodatno prispeval k razumevanju modela uspešnega sožitja turističnih krajev in pristanišč. V članku je kot primer prikazan razvoj turizma na Brionih v najbolj dinamičnem in dramatičnem zgodovinskem obdobju, tj. pred, med in po prvi svetovni vojni, ob upoštevanju njihovega pomena kot elitnega letovišča $\mathrm{v}$ neposredni bližini Pulja.

Ključne besede: aristokratske rezidence, letovišča, pristanišča, Brioni, Pulj, zgodovina turizma

Academica Turistica, 12(1), 31-40

\section{Turizem na hrvaški Jadranski obali in prva svetovna vojna} Jasenka Kranjčević

Raziskave o turistični zgodovini so bile večinoma omejene na upoštevanje življenjskih ciklov turističnega območja (ang. TALC). Čeprav so destinacije, ki imajo več kot stoletno turistično tradicijo, doživele različne življenjske cikle, se njihova turistična zgodovina redko obravnava $\mathrm{v}$ kontekstu globalnih sprememb, kot je prva svetovna vojna, in tega, kako in v kakšnem obsegu so te globalne spremembe vplivale na razvoj turizma ter turistično arhitekturo. Glede na to, da na območju današnje Hrvaške med prvo svetovno vojno ni prišlo do neposrednih sovražnosti, je v članku raziskan posredni vpliv vojne kot svetovnega dogodka na takratni dvig turizma s pomočjo neizkoriščene turistične arhitekture, kar je lahko razumeti kot ustavitev naložbe v turizem. Ta raziskava je lahko podlaga za razmišljanje o oblikovanju modela za svetovni turistični življenjski cikel po stopnjah, vključno s paradigmatskimi spremembami v oblikovanju turistične arhitekture.

Ključne besede: prva svetovna vojna, svetovni turistični cikel, življenjski cikel turističnega območja, neizkoriščena turistična arhitektura, Hrvaška Academica Turistica, 12(1), 41-53

\section{Preučitev sezonskosti potnih odhodkov po namenu potovanja: primer Japonske}

Kenichi Shimamoto

Obravnavanje sezonskosti za turistično industrijo je izziv za številne turistične destinacije. Japonska ni izjema in $\mathrm{z}$ nedavno osredotočenostjo na razvoj $\mathrm{v}$ turistično državo je postalo še pomembneje razumeti sezonske trende. Metode za obravnavanje sezonskosti, kot so diferencirano določanje cen, raznovrstna privlačnost, diverzifikacija trga in olajšave s strani države, bodo zahtevale segmentacijo trga za oblikovanje ustreznih strategij. Zato da bi zagotovili vpogled v sezonsko naravnanost različnih trgov, članek kategorizira izdatke, povezane s potovanji, $\mathrm{v}$ šest potrošniških postavk, 
vezanih na tako prostočasna kot poslovna potovanja. Članek preučuje trende in značilnosti sezonskosti in nihanja $\mathrm{v} v$ veh proračunskih letih med letoma 2010 in $2017 \mathrm{za}$ domača potovanja na Japonskem. Rezultati kažejo, da ne glede na namen potovanja obstajajo produkti, ki niso odvisni od sezonskosti in imajo relativno nizko fluktuacijo v opazovanem obdobju; gre za izdatke za prevoz, hrano, pijačo. Na drugi strani pa se pokažejo razmeroma visoke stopnje fluktuacije $\mathrm{v}$ opazovanem obdobju za produkte, kot so paketne počitnice ter stroški nastanitve za poslovna potovanja.

Ključne besede: sezonskost, potrošniška postavka, namen potovanja, Japonska Academica Turistica, 12(1), 55-72

\section{Razlike v zaznavi organizacijskih vrednot v hotelskem sektorju: kaj nam povedo? Mitja Gorenak}

Organizacijske vrednote so že nekaj let v žarišču pozornosti vodstev podjetij. Vedenje, da lahko trdne vrednote organizacijam pomagajo ohranjati pravo smer sredi hitro spreminjajočega se delovnega okolja, se je izkazalo kot trdna podlaga za njihovo uspešnost. Vendar pa organizacije niso nič brez svojih zaposlenih, kar nas je privedlo do vprašanja, kakšne so razlike $\mathrm{v}$ zaznavi organizacijskih vrednot med zaposlenimi glede na njihovo starost in spol. Raziskavo smo izvedli v hotelskem sektorju na reprezentativnem vzorcu 388 zaposlenih; ugotovili smo, da med zaposlenimi v hotelskem sektorju obstaja šest glavnih organizacijskih vrednot. V drugem delu raziskave smo ugotovili, da ženske pomembnost dveh od šestih vrednot vrednotijo statistično značilno višje kot moški. Glede na starost pa statistično značilnih razlik nismo našli. Ključne besede: vrednote, organizacijske vrednote, gostoljubje, demografija, zaznava Academica Turistica, 12(1), 73-82

\section{Blagovna znamka hotela kot sestavina blagovne znamke destinacije Elizabeth Abiola-Oke}

Namen tega članka je preučiti učinek razpoložljivosti hotelskih blagovnih znamk na določeni destinaciji na promocijo slednje. Podatki za raziskavo so bili zbrani s spletnimi vprašalniki. Udeležence raziskave smo izbrali prek socialnih omrežij (LinkedIn, na katerem ima avtor profil) in med člani različnih s turizmom povezanih ter nepovezanih skupin. $S$ turizmom povezane skupine sestavljajo strokovnjaki na tem področju pa tudi nestrokovnjaki. Podatke smo analizirali z deskriptivno analizo $\mathrm{s}$ programom SPSS. Ugotovili smo, da imajo blagovne znamke hotelov majhen vpliv na izbiro destinacije $\mathrm{v}$ primerjavi $\mathrm{z}$ drugimi sestavinami, kot so privlačnost destinacije, možnosti prevoza in druge podporne storitve. Na podlagi tega ugotavljamo, da blagovne znamke hotela ni mogoče uporabiti kot edini element blagovne znamke destinacije, saj ima nanjo zelo majhen vpliv oziroma ga sploh nima.

Ključne besede: hotelska blagovna znamka, destinacijska blagovna znamka, ciljni marketing, promocija destinacije

Academica Turistica, 12(1), 83-96 


\section{Instructions for Authors}

\section{Aim and Scope of the Journal}

Academica Turistica - Tourism and Innovation Journal (AT-TIJ) is a peer-reviewed journal that provides a forum for the dissemination of knowledge on tourism and innovation from a social sciences perspective. It especially welcomes contributions focusing on innovation in tourism and adaptation of innovations from other fields in tourism settings.

The journal welcomes both theoretical and applicative contributions and encourages authors to use various quantitative and qualitative research methodologies. Besides research articles, the journal also publishes review articles, commentaries, reviews of books and conference reports. Purely descriptive manuscripts which do not contribute to the development of knowledge are not considered suitable.

\section{General Guidelines and Policy of the Journal}

Manuscripts are accepted in both American and British English; however, consistency throughout the paper is expected. All manuscripts are subject to an initial editorial screening for adherence to the journal style, for anonymity, and for correct use of English. As a result of this your paper will be either accepted for further consideration or returned for revision. To avoid unnecessary errors you are strongly advised to have your manuscript proofread.

Manuscripts should be organized in the following order: title, abstract, keywords, main text, acknowledgements, references, and appendixes (as appropriate).

Reviewing. Each manuscript, meeting the technical standards and falling within the aims and scope of the journal, will be subject to double-blind review by two reviewers. Authors can propose up to two reviewers for revision of their work and also up to two reviewers they would like to avoid.

The referees are chosen by the Editorial Board. Assessments by the referees will be presented anonymously to the author and, in the case of substantial reservations, the article, with the list of corrections needed, will be returned to the author for correction. The corrected copy of the article with the list of corrections on a separate page should be returned to the Editorial Board.

Permissions. Authors wishing to include figures, tables, or text passages that have already been published elsewhere, are required to obtain permission from the copyright owner(s) and to include evidence that such permission has been granted when submitting their papers. Any material received without such evidence will be assumed to originate from the authors.

Submission declaration. Submission of a manuscript implies that it has not been published previously (except in the form of abstract or as part of a published lecture or academic thesis), that it is not under consideration for publication elsewhere, that its publication is approved by all its authors and tacitly or explicitly by the responsible authorities where the work was carried out. The corresponding author should ensure that all appropriate co-authors and no inappropriate co-authors are included on the paper, and that all coauthors have seen and approved the final version of the paper and have agreed to its submission for publication.

Conflict of interest. All authors are requested to disclose any actual or potential conflict of interest including any financial, personal or other relationships with other people or organizations within three years of beginning the submitted work that could inappropriately influence, or be perceived to influence, their work.

\section{Manuscript Preparation}

Manuscripts should be prepared according to the style prescribed by the Publication Manual of the American Psychological Association (American Psychological Association, 2009; see also http://www.apastyle.org).

Language and style. The first author is fully responsible for the language and style in the context of the instructions. A good scientific standard command of grammar and style is expected.

Text formatting. Please, use the automatic page numbering function to number the pages. Use tab stops or other commands for indents, not the space bar. Use the table function, not spreadsheets, to make tables. Use 
the equation editor or MathType for equations. Whenever possible, use the sI units (Système international d'unités).

The title page should include the title of the article (no more than 85 characters, including spaces), full name of the author(s), affiliation (institution name and address) of each author clearly identified; linked to each author by use of superscript numbers, corresponding author's full name, telephone, and e-mail address.

Abstract. The authors are obliged to prepare two abstracts - one in English and one (translated) in Slovene language. For foreign authors translation of the abstract into Slovene will be provided.

The content of the abstract should be structured into the following sections: purpose, methods, results, and conclusion. It should only contain the information that appears in the text as well. It should contain no reference to figures, tables and citations published in the main text, and should not exceed 250 words.

Beneath the abstract, the authors should supply appropriate keywords (3-6) in English and in Slovene. For foreign authors the translation of the abstract into Slovene will be provided.

The main text should contain a coherent and logical structure preferably following the IMRAD format (Introduction, Methods, Research [and] Discussion). However, other structures are also welcome (e.g. Introduction, Development and Conclusions) as long as the text maintains its logical structure and focus. Acknowledgments are optional.

The length of the articles should not exceed 9,000 words (including tables, figures, and references), double spaced, using Times New Roman font sized 12.

Tables. Each table should be submitted on a separate page in a Word document after References. Each table shall have a brief caption; explanatory matter should be in the footnotes below the table. The table shall contain means and the units of variation (SD, $\mathrm{SE}$, etc.) and must be free of nonsignificant decimal places. Abbreviations used in the tables must be consistent with those used in the text and figures. Definition symbols should be listed in the order of appearance, determined by reading horizontally across the table and should be identified by standard symbols. All tables should be numbered consecutively (Table 1, Table 2 , etc.).

Figures. Captions are required for all Figures and shall appear on a separate manuscript page, beneath table captions. Each figure should be saved as a separate file without captions and named as Figure 1, etc. Files should be submitted in ${ }^{*}$.tiff or ${ }^{*}$.jpeg format. Photographs should be saved at at least 300 dpi. Line art images should be saved at 1200 dpi. Lettering (symbols, letters, and numbers) should be between 8 and 9 points, with consistent spacing and alignment. Font face may be Serif (Minion) or Sans Serif (Myriad). Line width should be 0.5 point or greater. Any extra white or black space surrounding the image should be cropped. Ensure that subject-identifying information (i.e., faces, names, or any other identifying features) is cropped out or opaqued. Prior to publication, the author(s) should obtain all necessary authorizations for the publication of the illustrative matter and submit them to the Editorial Board. All figures should be numbered consecutively (Figure 1, Figure 2, etc.). The journal will be printed in black and white. If the paper contains graphs, we would appreciate that you also e-mail them in a separate Excel file.

\section{References}

References should be formatted according to the $\mathrm{Pu}$ blication Manual of the American Psychological Association (American Psychological Association, 2009).

The list of references should only include works that are cited in the text and that have been published or accepted for publication. Personal communications and unpublished works should only be mentioned in the text. References should be complete and contain all the authors (up to six) that have been listed in the title of the original publication. If the author is unknown, start with the title of the work. If you are citing a work that is in print but has not yet been published, state all the data and instead of the publication year write in print.'

Reference list entries should be alphabetized by the last name of the first author of each work. Do not use footnotes or endnotes as a substitute for a reference 
list. Full titles of journals are required (not their abbreviations).

\section{Citing References in Text}

One author. Tourism innovation specific is mentioned

(Brooks, 2010). Thomas (1992) had concluded ...

Two authors. This result was later contradicted (Swarbrooke \& Horner, 2007). Price and Murphy (2000) pointed out...

Three to five authors, first citation. Laroche, Bergeron, and Barbaro-Forleo (2001) had found ... It was also discovered (Salamon, Sokolowski, Haddock, \& Tice, 2013) ...

Three to five authors, subsequent citations. Laroche et al. (2009) or (Salamon et al., 2011).

Six or more authors. Wolchik et al. (1999) or (Wolchik et al., 1999).

If two references with six or more authors shorten to the same form, cite the surnames of the first author and of as many of the subsequent authors as necessary to distinguish the two references, followed by a coma and et al.

List several authors for the same thought or idea with separation by using a semicolon: (Kalthof et al., 1999; Biegern \& Roberts, 2005).

For detailed instructions please see the Publication Manual of the American Psychological Association (American Psychological Association, 2009, Chapter 6).

\section{Examples of Reference List}

Books

American Psychological Association. (2009). Publication manual of the American Psychological Association (6th ed.). Washington, DC: Author.

Swarbrooke, J., \& Horner, S. (2007). Consumer behaviour in tourism. Oxford, England: ButterworthHeinemann.

\section{Journals}

Laroche, M., Bergeron, J., \& Barbaro-Forleo, G. (2001). Targeting consumers who are willing to pay more for environmentally friendly products. Journal of Consumer Marketing, 18(6), 503-520.
Wolchik, S. A., West, S. G., Sandler, I. N., Tein, J.Y., Coatsworth, D., Lengua, L., ... Griffin, W. A. (200o). An experimental evaluation of theorybased mother and mother-child programs for children of divorce. Journal of Consulting and Clinical Psychology, 68, 843-856.

\section{Newspapers}

Brooks, A. (2010, 7 July). Building craze threatens to end Lanzarote's biosphere status. Independent. Retrieved from http://www.independent.co.uk/ environment/nature/building-craze-threatens-to -end-lanzarotes-biosphere-status-2020064.html

\section{Chapters in Books}

Poirier, R. A. (2001). A dynamic tourism development model in Tunisia: Policies and prospects. In Y. Aposotolopoulos, P. Loukissas, \& L. Leontidou (Eds.), Mediterranean tourism (pp. 197-210). London, England: Routledge.

\section{Conference Proceedings}

Price, G., \& Murphy, P. (2000). The relationship between ecotourism and sustainable development: A critical examination. In M. Ewen (Ed.), CAUTHE 200o: Peak performance in tourism and hospitality research; Proceedings of the Tenth Australian Tourism and Hospitality Research Conference (pp. 189202). Bundoora, Australia: La Trobe University.

\section{Paper Presentation}

Thomas, J. (1992, July). Tourism and the environment: An exploration of the willingness to pay of the average visitor. Paper presented at the conference Tourism in Europe, Durham, England.

\section{Theses and Dissertations}

Sedmak, G. (2006). Pomen avtentičnosti turističnega proizvoda: primer destinacije Piran (Unpublished doctoral dissertation). University of Ljubljana, Ljubljana, Slovenia.

\section{Working Papers}

Salamon, L. M., Sokolowski, S. W., Haddock, M. A., \& Tice, H. S. (2013). The state of global civil society volunteering: Latest findings from the implementation 
of the UN nonprofitt handbook (Comparative Nonprofit Sector Working Paper No. 49). Baltimore, MD: Johns Hopkins University.

\section{Web Pages}

Croatian Bureau of Statistics. (2001). Census of population, households and dwellings. Retrieved from http://www.dzs.hr/Eng/censuses/Census2001/ census.htm

For detailed instructions please see the Publication Manual of the American Psychological Association (American Psychological Association, 2009, Chapter 7$)$.

\section{Manuscript Submission}

The main manuscript document should be in Microsoft Word document format and the article should be submitted to http://pkp.turistica.si/index.php/test/ index

Please make sure that you do not leave any trace of your identity in the submitted files. Otherwise, your identity can be accidentally revealed to reviewers and your manuscript might be rejected.

We are introducing new manuscript submission system. The first responses from the authors are positive, but we still apologise for any inconvenience.

For technical assistance please contact mitja.petelin @turistica.si and for additional information regarding article publication contact the Editorial Board at academica@turistica.si 


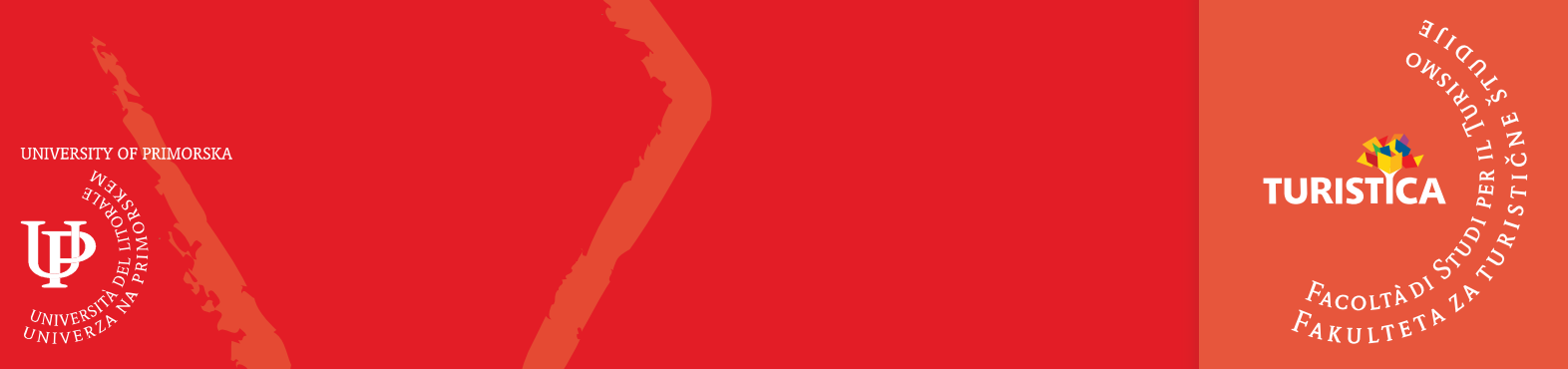